\title{
De arbeidsmarkt in de zorg- en welzijnssector : pilot- onderzoek onder werkgevers in Noord-Nederland
}

Citation for published version (APA):

van de Loo, P. J. E., \& van der Velden, R. K. W. (1993). De arbeidsmarkt in de zorg-en welzijnssector : pilot-onderzoek onder werkgevers in Noord-Nederland. Researchcentrum voor Onderwijs en Arbeidsmarkt, Faculteit der Economische Wetenschappen. ROA Reports No. 2 https://doi.org/10.26481/umarep.1993002

Document status and date:

Published: 01/01/1993

DOI:

10.26481/umarep.1993002

Document Version:

Publisher's PDF, also known as Version of record

\section{Please check the document version of this publication:}

- A submitted manuscript is the version of the article upon submission and before peer-review. There can be important differences between the submitted version and the official published version of record.

People interested in the research are advised to contact the author for the final version of the publication, or visit the DOI to the publisher's website.

- The final author version and the galley proof are versions of the publication after peer review.

- The final published version features the final layout of the paper including the volume, issue and page numbers.

Link to publication

\footnotetext{
General rights rights.

- You may freely distribute the URL identifying the publication in the public portal. please follow below link for the End User Agreement:

www.umlib.nl/taverne-license

Take down policy

If you believe that this document breaches copyright please contact us at:

repository@maastrichtuniversity.nl

providing details and we will investigate your claim.
}

Copyright and moral rights for the publications made accessible in the public portal are retained by the authors and/or other copyright owners and it is a condition of accessing publications that users recognise and abide by the legal requirements associated with these

- Users may download and print one copy of any publication from the public portal for the purpose of private study or research.

- You may not further distribute the material or use it for any profit-making activity or commercial gain

If the publication is distributed under the terms of Article $25 \mathrm{fa}$ of the Dutch Copyright Act, indicated by the "Taverne" license above, 


\section{DE ARBEIDSMARKT IN DE ZORG- EN WELZIJNSSECTOR}

- pilot-onderzoek onder werkgevers in Noord-Nederland -

ROA-R-1993/2

P.J.E. van de Loo

R.K.W. van der Velden

RESEARCHCENTRUM VOOR ONDERWIJS EN ARBEIDSMARKT

Faculteit der Economische Wetenschappen

Rijksuniversiteit Limburg

Maastricht, mei 1993 
CIP-GEGEVENS KONINKLIJKE BIBLIOTHEEK, DEN HAAG

Loo, P.J.E. van de

De arbeidsmarkt in de zorg- en welzijnssector: pilot-onderzoek onder werkgevers in NoordNederland / P.J.E. van de Loo, R.K.W. van der Velden. - Maastricht: Researchcentrum voor Onderwijs en Arbeidsmarkt, Faculteit der Economische Wetenschappen, Rijksuniversiteit Limburg. - (ROA-R-1993/2)

Met lit. opg.

ISBN 90-5321-104-7

Trefw.: arbeidsmarkt; gezondheidszorgwerkers / arbeidsmarkt; welzijnswerkers / onderwijs en arbeidsmarkt; Noord-Nederland 
INHOUDSOPGAVE

Bladzijde

VOORWOORD

SAMENVATTING

1. ARBEIDSMARKTSCANNER HSAO

1.1. De arbeidsmarktscanner voor het HSAO 1

1.2. Het werkgeversonderzoek 5

1.2.1. Opzet 5

1.2.2. Instrument 7

$\begin{array}{ll}\text { 1.3. Leeswijzer } & 10\end{array}$

2. DATAVERZAMELING EN RESPONS 11

2.1. Selectie en steekproef werkgevers 11

2.2. Dataverzameling en respons 12

3. PROFIEL ORGANISATIES IN ZORG- EN WELZIJNSSECTOR 15

$\begin{array}{ll}3.1 . & 15 \\ 3.2 . & 15\end{array}$

3.2. Kenmerken van organisaties in zorg- en welzijnssector 15

3.3. Omvang van organisaties in zorg- en welzijnssector 18

3.4. Conclusies 22

4. OMVANG EN SAMENSTELLING PERSONEEL IN SOCIAAL-AGOGISCHE FUNCTIES 24

4.1. Inleiding 24

4.2. Omvang van personeel in sociaal-agogische functies 25

4.3. Ontwikkelingen in omvang en samenstelling sociaal-agogische functies 28

4.4. Werving en selectie van sociaal-agogisch personeel 32

5. TOEKOMSTIGE BEHOEFTE AAN SOCIAAL-AGOGISCH PERSONEEL 36

5.1. Verwachtingen van werkgevers voor 1992 en $1993 \quad 36$

5.2. Arbeidsmarktperspectief voor sociaal-agogisch personeel: 40

een rekenvoorbeeld

6. SCHOLINGSBELEID VOOR SOCIAAL-AGOGISCH PERSONEEL

$\begin{array}{lll}\text { 6.1. Inleiding } & 45\end{array}$

6.2. Omvang scholing van sociaal-agogisch personeel 46

6.3. Motieven voor scholing van sociaal-agogisch personeel 51

7. CONTACTEN HSAO - WERKVELD 53

7.1. Contacten tussen HSAO en werkveld 53

$\begin{array}{lll}\text { 7.2. Behoefte aan regionale samenwerking } & 54\end{array}$ 
8. EVALUATIE EN GEBRUIKSMOGELIJKHEDEN

8.1. Evaluatie 57

8.2. Gebruiksmogelijkheden arbeidsmarktscanner 60

$\begin{array}{ll}\text { LITERATUUR } & 66\end{array}$

BIJLAGE 1. INDELING VAN ORGANISATIES IN ZORG- EN WELZIJNSINSTELLINGEN 68

BIJLAGE 2. SAMENSTELLING SOCIAAL-AGOGISCHE BEROEPENCLUSTERS

BIJLAGE 3. RESULTATEN PANELONDERZOEK PERSONEEL \& ARBEID 70 


\section{VOORWOORD}

In het kader van het project "Monitoringsysteem HSAO Werkveld", dat in opdracht van het Centrum voor Beroeps- en Opleidingsvraagstukken (СВO) van het Nederlands Instituut voor Zorg en Welzijn (NIZW) is ontwikkeld, heeft het Researchcentrum voor Onderwijs en Arbeidsmarkt (ROA) het afgelopen voorjaar een onderzoek onder werkgevers in de zorg- en welzijnssector in Noord-Nederland uitgevoerd. Het monitoringsysteem is er op gericht de aansluiting tussen het Hoger Sociaal-Agogisch Onderwijs (HSAO) en het werkveld in de zorg- en welzijnssector in kaart te brengen en waar nodig te verbeteren. Het Contactcentrum Onderwijs Arbeid (COA) Groningen coördineert de activiteiten van het monitoringsysteem HSAO Werkveld'. Het monitoringsysteem bestaat uit meerdere instrumenten om ontwikkelingen van bepaalde aspecten in deze aansluiting te signaleren (te 'monitoren'). Zo is het Werkveld Informatie Systeem (WIS) door het COA Groningen opgezet om het oordeel van de stagebiedende organisaties van de Rijkshogeschool Groningen (RHG) op te tekenen over een aantal aspecten van de HSAO-opleidingen van de RHG. Bovendien organiseert de RHG voor haar docenten in het kader van het monitoringsysteem zowel korte als lange stages in het werkveld.

Het ROA is verantwoordelijk geweest voor het derde instrument in het monitoringsysteem: de arbeidsmarktscanner. De arbeidsmarktscanner HSAO heeft tot doel de ontwikkelingen aan zowel de vraag- als aanbodzijde op de arbeidsmarkt in de zorg- en welzijnssector te inventariseren, zodat een beeld kan worden geschetst van de huidige en toekomstige arbeidsmarktperspectieven van afgestudeerde HSAO'ers. De arbeidsmarktscanner omvat twee deelonderzoeken die als complementair kunnen worden beschouwd: het onderzoek onder afgestudeerden en het onderzoek onder werkgevers. Over het onderzoek onder de afgestudeerden is onlangs een landelijk rapport uitgebracht ${ }^{2}$. Het voorliggende rapport bevat het verslag van het werkgeversonderzoek. Dit pilotonderzoek is uitgevoerd door drs. P.J.E. van de Loo onder leiding van dr. R.K.W. van der Velden. Bij de verwerking van de gegevens hebben drs. R.J.P. Dekker, drs. E.J.T.A. Willems, J.A. le, J.M.J.A. Pisters, M.E.C. Reiners assistentie verleend. Er is bij de uitvoering van het onderzoek dankbaar gebruik gemaakt van de adviezen van de leden van de Projectadviesgroep L.J.J. van der Ark, A.M. Kamoschinksky, drs. J. Gerritsma (NIZW), drs. A.M. Plaizier (HBO-Raad), drs. G.L.M. van Rienen (Ministerie van WVC), L. Koppejan (Stichting Lindenhof ( VOG) en van de andere projectteamleden drs. J.J. Dijkstra, drs. A.L. de Jong, drs. P.P.M. van Opheusden (COA Groningen), drs. F. Hengeveld en mr. W. Roseboom (RHG). Bovendien hebben N. Perrenet en $\mathrm{H}$. van Ewijk (NIZW) de adressen van organisaties uit de welzijnssector ter beschikking gesteld voor dit onderzoek.

Maastricht, mei 1993.

1. Over de opzet, uitvoering en gebruiksmogelijkheden van het gehele project wordt door het NIZW te Utrecht medio 1993 een handboek uitgebracht.

2. Dit rapport is evenals de rapportages die over de andere sectoren van het HBO in het kader van de HBO-Monitor zijn uitgebracht te bestellen bij de HBO-Raad te Den Haag. 


\section{SAMENVATTING}

\section{Monitoringsysteem HSAO - Werkveld}

In opdracht van het Centrum voor Beroeps- en Opleidingsvraagstukken (CBO) van het Nederlands Instituut voor Zorg en Welzijn (NIZW) is het Monitoringsysteem HSAO - Werkveld ontwikkeld. Dit monitoringsysteem is er op gericht de aansluiting tussen het Hoger SociaalAgogisch Onderwijs (HSAO) en het werkveld in de zorg- en welzijnssector in kaart te brengen en waar nodig te verbeteren. Het Contactcentrum Onderwijs Arbeid (COA) Groningen coördineert de activiteiten rondom dit monitoringsysteem. Het monitoringsysteem bestaat uit meerdere instrumenten om ontwikkelingen van bepaalde aspecten in de aansluiting te signaleren (te 'monitoren'). Zo is het Werkveld Informatie Systeem (WIS) door het COA Groningen opgezet om het oordeel van de stagebiedende organisaties van de Rijkshogeschool Groningen (RHG) op te tekenen over een aantal aspecten van de HSAO-opleidingen van de RHG. Bovendien organiseert de RHG voor haar docenten in het kader van het monitoringsysteem zowel korte als lange stages in het werkveld.

\section{Arbeidsmarktscanner}

Het ROA is verantwoordelijk geweest voor het derde instrument in het monitoringsysteem: de arbeidsmarktscanner. Deze arbeidsmarktscanner heeft tot doel de ontwikkelingen aan zowel de vraag- als aanbodzijde op de arbeidsmarkt in de zorg- en welzijnssector te inventariseren, zodat een beeld kan worden geschetst van de huidige en toekomstige ontwikkelingen voor het sociaal-agogisch arbeidsmarktsegment van de zorg- en welzijnssector. De arbeidsmarktscanner omvat twee deelonderzoeken die als complementair kunnen worden beschouwd: het onderzoek onder afgestudeerden, waarover onlangs een landelijk rapport is uitgebracht, en het voorliggende onderzoek onder werkgevers.

\section{Opzet werkgeversonderzoek}

Het werkgeversonderzoek heeft als doel periodiek kwantitatieve informatie te verzamelen over de huidige en - op korte termijn - te verwachten vraag naar afgestudeerde HSAO'ers en de mate waarin de HSAO'ers concurrentie ondervinden van andere categorieën opgeleiden. Bovendien beoogt het werkgeversonderzoek inzicht te bieden in het beleid ten aanzien van de werving, selectie en scholingsmogelijkheden van HSAO'ers en in de wijze waarop werkgevers contacten onderhouden met HSAO-opleidingen.

Het werkgeversonderzoek is het afgelopen jaar als 'proefonderzoek' uitgevoerd onder zorg- en welzijnsinstellingen in de provincies Groningen, Friesland en Drenthe. Het betreft hier dus een zogenaamd 'pilot' onderzoek, dat in principe dus alleen representatief is voor de drie noordelijke provincies. Het gaat bovendien om een 'panelonderzoek'. Hierbij wordt een representatieve groep werkgevers periodiek benaderd. Doordat in principe steeds dezelfde groep wordt geënquêteerd ontstaat er een continue informatiestroom die een goed inzicht kan bieden in de 
ontwikkeling (in bijvoorbeeld de personeelssamenstelling) in instellingen. Bij cross-sectioneel onderzoek kan men namelijk niet zien of geconstateerde veranderingen toe te schrijven zijn aan bepaalde trendmatige ontwikkelingen in de sector, dan wel een gevolg zijn van het feit dat de steekproef van werkgevers bij herhaalde metingen steeds anders is.

\section{Dataverzameling en respons}

Voorjaar 1992 is een panel van circa 200 werkgevers in de zorg- en welzijnssector in de drie noordelijke provincies benaderd. Na telefonisch rappèl bleken 69 organisaties de vragenlijst ingevuld te hebben geretourneerd, waarvan 55 organisaties tot de bedoelde populatie bleken te behoren; 22 tot de zorginstellingen, 33 tot de welzijnsorganisaties. Het responspercentage onder de bereikte organisaties bedraagt $48 \%$, hetgeen voor dit type onderzoek zeker geen lage respons is. Er bleken nogal wat organisaties onbereikbaar door ziekte of afwezigheid van de contactpersonen (directie of hoofd personeelszaken). En in met name de welzijnssector was een behoorlijk aantal - vooral kleine - organisaties onbereikbaar, doordat deze inmiddels waren verhuisd, opgeheven of gefuseerd.

Aangezien het pilot-onderzoek in eerste instantie is bedoeld om de arbeidsmarkt voor hoger geschoold sociaal-agogisch personeel in de zorg- en welzijnssector in kaart te brengen, worden de organisaties die uitsluitend $\mathrm{P} \& \mathrm{O}$-functies bij de opgave van sociaal-agogische formatieplaatsen hebben gemeld buiten de rest van het werkveldonderzoek gehouden. Het gaat hier om tien grote organisaties in de profit- en non-profitsector (buiten de zorg- en welzijnssector). In totaal waren er eind 1991 ruim 65 formatieplaatsen voor P\&O-functies bij deze tien organisaties aanwezig.

\section{Profiel zorg-en welzijnsorganisaties}

Er blijken enkele belangrijke verschillen te bestaan tussen de zorg- en welzijnsorganisaties. In vergelijking met de zorginstellingen zijn de welzijnsorganisaties over het algemeen jonger, op gemeentelijk in plaats van provinciaal of landelijk niveau actief, kleiner naar zowel personeelsomvang, als totale budget en bruto totale loonsom, en gaat het bij de welzijnsorganisaties vaker om een hoofdvestiging, terwijl naar verhouding veel onderzochte zorginstellingen nevenvestigingen van een grotere organisatie betreffen. Hoewel in 1991 de zorginstellingen vaker bij reorganisaties als fusies en verzelfstandigingen betrokken waren, zijn het voor de periode $1992 / ' 93$ vaker de welzijnsorganisaties die een reorganisatie verwachten.

\section{Ontwikkelingen personeel in sociaal-agogische functies}

Binnen het totaal van het sociaal-agogisch personeel vormen de sociaal-pedagogische hulpverleners en maatschappelijk werkers, gevolgd door de leidinggevenden in de zorg- en welzijnssector de belangrijkste beroepsgroepen. Cultureel werkers, personeelswerkers en beleidsmedewerkers zorg en welzijn vormen daarentegen in totaal nog geen $6 \%$ van het totaal sociaal-agogisch personeel in de onderzochte organisaties, dat eind 1991 ruim 1400 werknemers bedroeg. 
In 1991 blijkt de instroom van werknemers de uitstroom te overtreffen. Per saldo zijn er in 1991 in de onderzochte organisaties 35 sociaal-agogische personeelsleden bijgekomen, een toename van ruim $2,5 \%$ ten opzichte van het begin van dat jaar. Daarnaast zijn er 116 sociaal-agogische werknemers de organisaties binnengekomen om personeel dat in 1991 is vertrokken te vervangen. De vervangingsvraag in 1991 bedroeg derhalve ruim $8,4 \%$. De toename van sociaalagogisch personeel blijkt echter alleen het vrouwelijk personeel te betreffen. Per saldo is er in 1991 bij de mannen namelijk meer sociaal-agogisch personeel uitgestroomd dan ingestroomd. Het percentage vrouwen in het totale sociaal-agogisch personeel neemt dan ook toe, alhoewel dit personeel eind 1991 (nog steeds) voor meer dan de helft (55\%) uit mannen bestaat. Overigens blijkt er geen noemenswaardig verschil in mobiliteit tussen mannen en vrouwen te bestaan $(8,5$ versus 8,3 procent).

Er bestaan wel grote mobiliteitsverschillen tussen de leeftijdsklassen. Terwijl in de klasse tot 30 jaar het mobiliteitspercentage $12,3 \%$ en in de klasse van 50 jaar en ouder zelfs $14,5 \%$ bedraagt, is het percentage voor het sociaal-agogisch personeel tussen de 30 en 50 jaar slechts de helft hiervan: namelijk $6,4 \%$. Het hogere percentage bij de ouderen duidt op een forse uittrede uit de arbeidsmarkt. De jongeren zijn daarentegen duidelijk nog op zoek naar een passende baan, waarbij niet uitgesloten moet worden dat dit een gevolg is van onvrijwillig 'jobhoppen' van de ene tijdelijke baan naar de andere tijdelijke baan.

Verwachtingen omtrent werkgelegenheid voor 1992 en 1993

Voor het goed kunnen (uit)voeren van bijvoorbeeld personeels- en scholingsbeleid is het nodig om inzicht te hebben in de (toekomstige) vraag en het aanbod van (potentiële) sociaal-agogische beroepskrachten. Voor het in kaart brengen van de arbeidsmarktontwikkelingen aan de vraagzijde hebben de werkgevers hun verwachtingen uitgesproken met betrekking tot de werkgelegenheidsontwikkeling voor 1992 en 1993 in de organisatie in het algemeen en ten aanzien van het sociaal-agogisch personeel in het bijzonder. Bovendien hebben de werkgevers een indicatie gegeven van het aantal vacatures dat zij de komende twee jaar bij het sociaalagogisch personeel verwachten.

Tevens is de werkgevers gevraagd welke externe en interne veranderingen zij in 1992 en 1993 verwachten met betrekking tot de organisatie. Het vaak samenhangende trio van bezuinigingsen budgetteringsoperaties van subsidieverschaffers, herstructurering van hulpaanbod en doelgroep en fusies en samenwerkingscontracten werd het vaakst als de belangrijkste externe verandering genoemd. Intern gaan reorganisaties en het opzetten en uitvoeren van nieuwe activiteiten een belangrijke rol spelen. Bovendien noemde bijna een kwart van de zorginstellingen veranderingen ten aanzien van het scholings-, personeels- en ziekteverzuimbeleid.

Een kwart van de werkgevers verwacht in 1992 en 1993 een toename van de werkgelegenheid in de gehele organisatie, $31 \%$ verwacht een afname en $44 \%$ denkt dat de werkgelegenheid in de organisatie in deze periode gelijk blijft. In de zorgsector verwacht $70 \%$ van de werkgevers zelfs geen enkele werkgelegenheidsverandering, terwijl dit slechts voor $28 \%$ van de welzijnsor- 
ganisaties geldt. Het zijn met name de kleine organisaties (met minder dan 10 werknemers) die een toename van de werkgelegenheid verwachten: namelijk $60 \%$ van deze kleine organisaties. Organisaties die naar verwachting in 1992 of 1993 bij een fusie of overname worden betrokken verwachten vaker een verandering in de werkgelegenheid dan organisaties die hier niet mee te maken zeggen te krijgen (63\% versus $31 \%$ ). Overigens verwachten de bij een fusie betrokken organisaties even vaak een toename als een afname in de werkgelegenheid.

Wanneer het sociaal-agogisch personeel wordt gewogen naar grootte van de beroepenclusters blijkt dat voor $23 \%$ van het sociaal-agogisch personeel een toename in de werkgelegenheid wordt verwacht en voor $15 \%$ een afname. Voor de resterende $63 \%$ wordt geen verandering voorzien. Voor de maatschappelijk werkers wordt relatief vaak een groei in de werkgelegenheid verwacht, terwijl de leidinggevenden daarentegen naar verwachting met een afnemende werkgelegenheid te maken zullen krijgen.

Het bleek voor veel werkgevers moeilijk om een schatting te geven van het aantal vacatures dat zij de komende twee jaar voor het sociaal-agogisch personeel verwachten. Circa de helft van de werkgevers heeft de vraag over de vacatures beantwoord, hetgeen bijna driekwart van de sociaal-agogische formatieplaatsen betreft. Omgerekend naar de gehele formatie van sociaalagogisch personeel betekent dit dat er in 1992 en 1993 in totaal bijna 250 vacatures door de werkgevers in de drie noordelijke provincies worden verwacht. Voor het totale sociaal-agogisch personeel bedraagt het relatieve aandeel van de vacatures ten opzichte van het totaal aantal werkenden eind 1991 circa $17,5 \%$. Op jaarbasis bijna $9 \%$ hetgeen iets lager is dan het aantal vacatures dat in 1991 ruim $11 \%$ bedroeg van het totaal aan sociaal-agogisch personeel aan het begin van 1991 .

\section{Toekomstige werkgelegenheid sociaal-agogisch personeel: een rekenvoorbeeld}

Met behulp van de door de werkgevers verschafte gegevens over de veranderingen in het personeelsbestand over het afgelopen jaar en gegevens over toekomstige arbeidsmarktontwikkelingen uit het ROA-informatiesysteem is een rekenvoorbeeld gepresenteerd van de mogelijke ontwikkelingen aan de vraag- en aanbodzijde op de arbeidsmarkt in de zorg- en welzijnssector voor de komende twee jaar. Bedacht moet worden dat het hier gaat om een rekenvoorbeeld. De gepresenteerde berekening dient vooral de mogelijkheden van dit type onderzoek aant te geven en kan dus niet worden beschouwd als een exacte voorspelling. Aangezien het hier om een pilot-onderzoek gaat en de benodigde gegevens niet altijd volledig beschikbaar waren, waardoor het rekenvoorbeeld een aantal - wellicht niet geheel juiste - vooronderstellingen bevat, kunnen aan de uitkomsten van dit rekenvoorbeeld ook geen conclusies worden verbonden.

\section{Uitbreidingsvraag}

Voor de toekomstige uitbreidingsvraag is uitgegaan van de landelijke prognose voor de beroepsklasse van maatschappelijk werkers e.d. uit het ROA-informatiesysteem. Naar verwachting zal de werkgelegenheid tussen 1989 en 1994 in deze beroepsklasse in Nederland met 6\% 
toenemen; in vergelijking met de andere ROA-beroepsklassen een gemiddelde groei. Ervan uitgaande dat de jaarlijkse groei tussen 1989 en 1994 gelijk blijft, wordt dus voor de periode 1992-1993 een groei van ruim $2 \%$ verwacht, oftewel 30 personen. Dat wil zeggen dat op jaarbasis de groei van de werkgelegenheid ten opzichte van de groei in 1991 wordt gehalveerd.

\section{Vervangingsvraag}

De vervangingsvraag, die ondermeer het gevolg is van pensionering, (tijdelijke) terugtrekking van de arbeidsmarkt en beroepsmobiliteit, wordt bepaald door de in de analyseperiode waargenomen geslachts- en leeftijdspecifieke verloopcoëfficiënten door te trekken naar de toekomst. Daarbij wordt gecorrigeerd voor de uitstroom van werkenden naar het werklozenbestand en voor de verwachte ontwikkeling van de participatiegraad per geslacht en leeftijdscategorie. Doorberekening van deze vervangingsvraag op het gebruikte zorg- en welzijnsbestand voor de periode 1992-1993 levert een totaal aantal van 290 personen op. Gerelateerd aan het totaal aantal personen dat in 1991 in de onderzochte organisaties in een sociaal-agogische functie werkzaam was, bedraagt de procentuele vervangingsvraag ruim $20 \%$, oftewel $10 \%$ op jaarbasis. Hierbij is ook de vervanging meegerekend van personeel dat bij een andere organisatie is gaan werken. Van deze 'baanopeningen' zijn er ongeveer 70 bestemd voor nieuwkomers op de arbeidsmarkt.

\section{Arbeidsmarktperspectief}

Het totaal aantal baanopeningen voor nieuwkomers in sociaal-agogische functies in de onderzochte organisaties wordt derhalve voor 1992 en 1993 tezamen op circa 100 personen geschat. Aangezien ongeveer één op de zes sociaal-agogische beroepsbeoefenaren uit NoordNederland in eén van de onderzochte organisaties werkzaam was, bedraagt het aantal baanopeningen voor sociaal-agogisch personeel voor 1992 en 1993 in de drie Noordelijke provincies ongeveer 600 personen. Om deze baanopeningen concurreren HSAO'ers en andere HBO'ers met afgestudeerden van het WO en MBO. Naar schatting de helft van deze baanopeningen zullen vrij komen voor afgestudeerden van het voltijds HSAO. Met andere woorden: 300 plaatsen komen vrij voor afgestudeerden van het voltijdse HSAO.

Op basis van onderwijsprognoses van het Ministerie van Onderwijs en Wetenschappen en onderwijsstatistieken van het Centraal Bureau voor de Statistiek (CBS) wordt in 1992 en 1993 een aanbod van (al dan niet werkloze) afgestudeerden van het voltijdse HSAO in NoordNederland van ongeveer 400 personen verwacht.

Uitgaande van het berekende aantal baanopeningen betekent dit dat het aanbod de vraag enigzins zal overtreffen, hetgeen kan betekenen, dat niet alle afgestudeerde HSAO'ers werk in hun arbeidsmarktsegment zullen kunnen vinden. Hierbij moet niet uit het oog worden verloren, dat de afgestudeerden van het (voltijds) HSAO op een vrij open arbeidsmarktsegment opereren. Enerzijds zullen de HSAO'ers juist de lager geschoolde MDGO'ers verdringen, waarbij HSAO'ers de kans lopen dat hun kwalificaties worden onderbenut. Anderzijds kunnen de HSAO'ers op hun 
-vii-

beurt weer veel concurrentie ondervinden van universitair geschoolden. Daarnaast concurreren afgestudeerde $\mathrm{HSAO}^{\prime}$ ers met het bestaande sociaal-agogisch personeel om de vrij te komen arbeidsplaatsen. Ouder sociaal-agogisch personeel heeft, met name in het verleden, nogal eens 'het veld moeten ruimen' voor pas afgestudeerde HSAO'ers. Een verschijnsel dat zich overigens niet tot de zorg- en welzijnssector heeft beperkt. Ten slotte kunnen afgestudeerde HSAO'ers er ook voor kiezen om eerst nog enkele jaren verder te studeren, om daarmee een betere uitgangspositie voor een (goede) baan in de zorg- en welzijnssector te verwerven. Voor een goed inzicht in de uiteindelijke resultaten van dit selectieproces wordt verwezen naar de HBOMonitor, het onderzoek onder de afgestudeerden, dat juist antwoord geeft op dit soort vragen.

\section{Werving en selectie van sociaal-agogisch personeel}

$\mathrm{Er}$ is nagegaan welke opleidings- en werkervaringseisen werkgevers aan het in 1991 aangenomen sociaal-agogisch personeel hebben gesteld, om inzicht te krijgen in de concurrentie tussen verschillende aanbodcategorieën op de arbeidsmarkt voor sociaal-agogische functies in de zorgen welzijnssector. Daarnaast is de werkgevers gevraagd aan te geven of het aangenomen personeel binnen (intern) of buiten (extern) de eigen organisatie is geworven.

Van het totaal in 1991 (extern) geworven sociaal-agogisch personeel heeft $48 \%$ een opleiding op HBO-niveau genoten, $40 \%$ ten hoogste een opleiding op MBO-niveau gehad en $12 \%$ een opleiding hoger dan een initiële $\mathrm{HBO}$-opleiding (universitaire of voortgezette $\mathrm{HBO}$-opleiding). Bij de in 1991 aangenomen sociaal-pedagogische hulpverleners bedraagt het percentage MBOgeschoolden zelfs $49 \%$, terwijl omgekeerd $63 \%$ van de instromers in leidinggevende zorg- en welzijnsfuncties een universitaire of voortgezette HBO-opleiding heeft genoten. Het zijn met name de kleine organisaties met minder dan 10 werknemers die personeel op MBO-niveau hebben geworven (65\% van de instromers aldaar). Deze organisaties hebben zelfs niemand boven initieel HBO-niveau in 1991 aangenomen, c.q. kunnen aannemen. Bij de middelgrote organisaties is het percentage instromers met een opleiding op HBO-niveau met $66 \%$ relatief hoog.

Een kwart van het totaal in 1991 ingestroomde personeel heeft minder dan 1 jaar werkervaring, terwijl ruim een kwart meer dan 5 jaar werkervaring heeft opgedaan alvorens in de betreffende organisatie te zijn aangenomen. Bij de leidinggevenden is het percentage dat meer dan 5 jaar werkervaring heeft relatief hoog (47\%), terwijl bij de sociaal-pedagogische hulpverleners juist het procentuele aandeel van instromers met een middellange werkervaring hoog kan worden genoemd $(61 \%)$. Tussen de zorg- en welzijnssector blijken er op dit punt geen verschillen te bestaan. De organisaties met minimaal 50 werknemers blijken naar verhouding vaker sociaalagogisch personeel met minder dan een jaar werkervaring te hebben aangesteld. In grotere organisaties kunnen mensen met weinig of geen werkervaring blijkbaar makkelijker worden ingepast, dan in kleinere organisaties waarin het nieuwe personeel waarschijnlijk direct volledig inzetbaar moet kunnen zijn. 
-viii-

Tweederde van het in 1991 aangenomen sociaal-agogisch personeel blijkt extern te zijn geworven en éénderde intern. Naar verhouding zijn de sociaal-pedagogische hulpverleners vaker intern geworven (42\%), terwijl de leidinggevenden juist vaker via externe kanalen zijn aangetrokken $(86 \%)$. Wederom bestaan er tussen de zorg- en welzijnssector geen noemenswaardige verschillen. Wel blijken de kleine organisaties (met minder dan 10 werknemers) relatief vaak een interne kandidaat te hebben aangenomen $(63 \%)$.

\section{Scholingsbeleid zorg-en welzijnssector}

Wat betreft de omvang van de aanvullende scholing van sociaal-agogisch personeel kan worden opgemerkt, dat $86 \%$ van de zorginstellingen en $88 \%$ van de welzijnsorganisaties minimaal één sociaal-agogisch personeelslid in 1991 een interne of externe cursus heeft laten volgen.

Het deelnemingspercentage ${ }^{3}$ is voor de welzijnssector hoger dan voor de zorgsector $156 \%$ versus $31 \%$ ) en loopt af bij een toenemende personeelsomvang: $56 \%$ voor organisaties met minder dan 10 personen, $31 \%$ voor organisaties met minimaal 50 personen. Organisaties waarbij het budget tussen 1990 en 1992 jaarlijks met minder dan $1 \%$ is gegroeid en/of een (sterke) afname van de werkgelegenheid tussen 1992 en 1993 verwachten en/of in 1991 wel bij een reorganisatie betrokken waren hebben relatief een hoog deelnemingspercentage.

Per deelnemer kostte de scholingsactiviteiten in 1991 gemiddeld $f 2.100$,-- en bedroeg de gemiddelde gederfde werktijd 8 dagen. Hierbij bestaat er nauwelijks verschil tussen de zorg- en welzijnsinstellingen. Welzijnsorganisaties hebben verhoudingsgewijs meer geld besteed aan externe scholingsactiviteiten dan de zorginstellingen ( $80 \%$ versus $64 \%$ ). De verschillen in scholingsbeleid tussen de zorg- en welzijnssector hangen vaak samen met hun verschil in personeelsomvang.

Inwerken bleek voor de werkgevers het belangrijkste motief te zijn om hun sociaal-agogisch personeel bij te scholen: $77 \%$ noemde dit motief. Ruim de helft van de organisaties $156 \%$ ) noemde daarnaast 'bijblijven' een belangrijk motief voor scholingsactiviteiten. Aanvullende scholing in verband met promotie van sociaal-agogisch personeel wordt daarentegen erg weinig genoemd $(13 \%)$.

\section{Contacten HSAO - werkveld}

Driekwart van de onderzochte organisaties heeft momenteel contact met een HSAO-opleiding in de regio, terwijl $85 \%$ aangeeft aan dit contact behoefte te hebben. De zorginstellingen hebben vaker (behoefte aan) contact met het HSAO dan de welzijnsorganisaties (feitelijk contact: $86 \%$ versus $67 \%$; gewenst contact: $90 \%$ versus $81 \%$ ). Stages door studenten worden het vaakst

3. Het deelnemingspercentage betreft het procentuele aandeel van het sociaal-agogisch personeel dat in 1991 scholingsactiviteiten heeft gevolgd. Het gaat hier om organisaties waarbij minimaal én sociaalagogisch personeelslid in 1991 scholing heeft gevolgd. Indien een werknemer in dat jaar aan meerdere scholingsactiviteiten deelnam is deze slechts éénmaal als deelnemer meegeteld. 
genoemd, terwijl gastdocentschappen en voorlichting, stages door docenten en overleg over aansluitingsproblemen ook regelmatig worden aangegeven als (mogelijke) contactpunten.

Drie op de vijf organisaties heeft behoefte aan een regionale voorziening die de instrumenten van het monitoringsysteem HSAO - werkveld beheert en waarbij zowel de regionale werkgevers als opleidingen zijn betrokken. Hiervan zou ruim driekwart $(78 \%)$ bij de opzet van een dergelijke voorziening betrokken willen worden, terwijl $81 \%$ in zo'n platform zou willen participeren. De percentages zijn voor de zorginstellingen steeds iets hoger dan voor de welzijnsorganisaties.

\section{Evaluatie en gebruiksmogelijkheden}

Zoals gezegd is dit pilot-onderzoek in de eerste plaats uitgevoerd om na te gaan wat de mogelijkheden zijn van een (panel)onderzoek onder werkgevers om (toekomstige) ontwikkelingen aan de vraagzijde van de arbeidsmarkt op te sporen en in kaart te brengen. Bij het pilotonderzoek zijn de gegevens middels een schriftelijke vragenlijst verzameld. Op termijn is het wellicht mogelijk de werkgevers een (software)produkt, c.q. informatiesysteem aan te bieden, waarmee zij het eigen personeels- en scholingsbeleid goed in de gaten kunnen houden. Een soort van 'human accounting'.

Bij een (eventueel) verdere opzet van het werkgeversonderzoek zullen daarnaast de volgende zaken in het oog worden gehouden. Ten eerste is het werkgeversonderzoek complementair aan het afgestudeerdenonderzoek (het andere instrument uit de arbeidsmarktscanner). Overlap in gegevensverzameling moet dus worden vermeden. Bovendien moeten de gebruiksmogelijkheden van de arbeidsmarktscanner en de daarbij behorende doelgroepen leidraad zijn bij een verdere uitwerking van het werkgeversonderzoek. Het instrument van het werkgeversonderzoek, c.q. de arbeidsmarktscanner is ten slotte niet het doel. Het instrument wordt immers opgezet om in de informatiebehoefte bij de verschillende gebruikersgroepen te voorzien.

Naast individuele werkgevers en het georganiseerde werkveld zijn individuele onderwijsinstellingen en het georganiseerde onderwijsveld, overheden, arbeidsbemiddelaars e.a. intermediairs op het gebied van de aansluiting onderwijs - werkveld ook belangrijke gebruikersgroepen. De gebruiksmogelijkheden van de arbeidsmarktscanner liggen in feite op de volgende vier beleidsterreinen: voorlichting, kwaliteitszorg, scholing en personeelsbeleid.

Vaak is het zo dat meerdere gebruikersgroepen bij het ontwikkelen en uitvoeren van een bepaalde activiteit zijn betrokken. Daarnaast moge het duidelijk zijn dat deze vier beleidsterreinen niet los van elkaar staan.

De arbeidsmarktscanner verschaft de gebruikersgroepen in de eerste plaats een aantal indicatoren omtrent de kwaliteit van zowel de kwantitatieve als kwalitatieve aansluiting tussen onderwijs en werkveld. Bij de kwalitatieve aansluiting gaat het dan om de afstemming binnen de werksituatie tussen de capaciteiten van een werknemer en de voor een adequate vervulling van de functie vereiste kennis en vaardigheden. Kwantitatieve aansluitingsproblemen treden op de 
arbeidsmarkt op wanneer er een tekort of een overschot is aan arbeidskrachten voor een bepaald soort functies.

De gegevens uit de arbeidsmarktscanner spelen voor individuele werkgevers een directe rol bij het personeelsbeleid. Hieruit kunnen zij indicatoren afleiden die voor de volgende elementen van het personeelsbeleid van belang kunnen zijn: wervings- en selectiebeleid (wervingsstrategieën, de marktpositie van de organisatie bij het aantrekken van personeel), loopbaanbegeleiding, scholingsbeleid, functie-analyse en functiewaardering.

Daarnaast kunnen werkgevers de informatie uit de arbeidsmarktscanner gebruiken bij voorlichtingsactiviteiten of voor regionaal overleg tussen onderwijs-, werkveld en arbeidsvoorziening over een verbetering van eventuele aansluitingsproblemen.

Voor een uitgebreid overzicht van de gebruiksmogelijkheden voor de verschillende gebruikersgroepen van de arbeidsmarktscanner wordt verwezen naar het handboek dat medio 1993 zal worden uitgebracht. 


\section{ARBEIDSMARKTSCANNER HSAO}

\subsection{De arbeidsmarktscanner voor het HSAO}

\section{Aans/uiting HSAO op werkveld}

Met de in 1983 gestarte herstructureringsoperatie Schaalvergroting, Taakverdeling en Concentratie (STC-operatie) is een aantal ingrijpende ontwikkelingen in het hoger beroepsonderwijs in gang gezet. Deze ontwikkelingen beogen autonomere HBO-instellingen die minder afhankelijk zijn van de centrale overheid. Hierbij kan het HBO zich juist door een sterke gerichtheid op de externe omgeving profileren. De toegenomen autonomie voor het HBO heeft als keerzijde een uitbreiding van de toetsing op kwaliteit en (macro) doelmatigheid. Voor een verantwoording van de kwaliteit van ondermeer de onderwijstaken in het $\mathrm{HBO}$ is een stelsel van kwaliteitsbewaking hierbij een eerste vereiste.

Eén van de criteria waarop de kwaliteit van het hoger beroepsonderwijs beoordeeld zal gaan worden is de aansluiting tussen onderwijs en werkveld. Ook in de zorg- en welzijnssector vormen zowel de kwalitatieve als de kwantitatieve knelpunten in deze aansluiting al een aantal jaren een punt van zorg.

Door de maatschappelijke ontwikkelingen op economisch, technologisch, politiek-bestuurlijk en sociaal-cultureel terrein, alsmede een aantal ingrijpende organisatorische veranderingen in de zorg- en welzijnssector, is er sprake van een sterke dynamiek in de beroepsuitoefening en het werkveld. Deze zullen grote gevolgen hebben voor de huidige èn toekomstige beroepsbeoefenaren (Van der Top, 1989). De kwalitatieve aansluiting tussen opleiding en beroepenveld kan door deze ontwikkelingen onder druk komen te staan.

Dit geldt eveneens voor de kwantitatieve aansluiting tussen het hoger sociaal-agogisch onderwijs en het beroepenveld. De sterke groei van de sector zorg en welzijn uit de jaren zeventig en tachtig lijkt tot stilstand gebracht. Daarnaast is de vervangingsbehoefte binnen deze sector is, gelet op de leeftijdsopbouw, relatief gering waardoor weinig nieuwe baanopeningen zullen ontstaan. De tot voor kort sterke verkokering van het veld leidde er bovendien toe dat de substitutie-elasticiteit vrij gering was en er derhalve weinig uitwijkmogelijkheden waren naar andere beroepen in de sector. Hierdoor werd de kans op kwantitatieve discrepanties vergroot. Inmiddels zijn er in het HSAO een aantal verwante studierichtingen samengevoegd en zijn door fusies grotere zorg- en welzijnsorganisaties ontstaan, hetgeen waarschijnlijk een positieve invloed zal hebben op de kwantitatieve aansluiting.

\section{Behoefte aan informatie over aans/uitingsvraagstuk}

Met het oog op de gesignaleerde knelpunten in de aansluiting tussen het HSAO en het werkveld blijkt er in toenemende mate behoefte te bestaan aan actuele informatie over relevante ontwikkelingen in dit aansluitingsvraagstuk. Voor hogescholen heeft dergelijke informatie een 
belangrijke functie in een systeem voor kwaliteitsbewaking en zelfevaluatie, zoals in 1990 nog eens door de commissie Rauwenhoff werd benadrukt. Voorts speelt arbeidsmarktinformatie een belangrijke rol in de voorlichting aan (aankomende) studenten, de planning van de onderwijscapaciteit, de inrichting van het curriculum, het contractonderwijs en het stage- en alumnibeleid. In werkgeverskringen leeft een vergelijkbare informatiebehoefte. Voor werkgevers en hun personeelsfunctionarissen is het eveneens van belang om inzicht te hebben in de ontwikkelingen op de arbeidsmarkt en in het onderwijs, waarbij zij met name waarde hechten aan accurate informatie over de huidige en prognoses over de toekomstige aansluiting tussen een bepaalde opleiding en het werkveld. Immers, vroegtijdig signaleren van bijvoorbeeld tekorten of overschotten van bepaalde afgestudeerden op de arbeidsmarkt maakt tijdige actie mogelijk. Hierbij kan men denken aan promotiecampagnes, andere wervingsstrategieën, bijscholing van afgestudeerden uit verwante vakrichtingen e.d. Naast het werkveld en de HSAO-opleidingen zijn er nog andere belanghebbenden die graag gebruik maken van informatie over de arbeidsmarktpositie van afgestudeerden van het HSAO. Dat zijn niet alleen aankomende studenten en hun ouders, maar tevens de afgestudeerden zelf en hun beroepsverenigingen, decanen, branche-organisaties, de ministeries van Onderwijs \& Wetenschappen, Sociale Zaken \& Werkgelegenheid, Welzijn, Volksgezondheid \& Cultuur, alsmede intermediaire organisaties op landelijk en regionaal niveau, zoals bijvoorbeeld het CBA en de RBA's (respectievelijk het Centraal en Regionaal Bestuur voor de Arbeidsvoorziening), evenals het LDC en RDC's (respectievelijk Landelijk en Regionaal Dienstverlenend Centrum) die zijn gericht op dienstverlening bij de studie- en beroepskeuzevoorlichting. Sinds kort zijn ondermeer de COA's opgegaan in deze RDC's. Uiteraard hebben ook onderzoekers die zich bezig houden met het aansluitingsvraagstuk behoefte aan (statistische) gegevens over arbeidsmarktontwikkelingen in het algemeen en data over de aansluiting tussen opleidingen en het werkveld in het bijzonder.

Hoewel de genoemde belanghebbenden niet allemaal precies dezelfde informatiebehoefte hebben, zou men in ieder geval inzicht willen hebben in:

- de kansen op werk na het verlaten van de opleiding, in het bijzonder in de beroepsdomeinen waarop het HSAO beoogt aan te sluiten;

- het inkomen, de arbeidsvoorwaarden en de carrièremogelijkheden in deze beroepsdomeinen;

- de verworven kwalificaties in de opleiding in relatie tot de eisen in de beroepsuitoefening;

- de omvang en samenstelling van de toekomstige uitstroom uit het HSAO;

- de verwachte ontwikkeling in de uitbreidings- en vervangingsvraag van sociaal-agogische functies;

- het scholingsbeleid in de sector zorg en welzijn.

Juist onderzoek onder enerzijds de afgestudeerden van het HSAO aan de aanbodzijde en anderzijds het werkveld waarop het HSAO zich richt aan de vraagzijde van de arbeidsmarkt kan in deze informatiebehoefte voorzien.

\section{Standaardisatie arbeidsmarktonderzoek}

Echter, hoewel in de afgelopen jaren veel onderzoek is verricht onder de afgestudeerden van het 
hoger onderwijs, is de informatieve waarde hiervan toch vaak betrekkelijk. Dit blijkt ondermeer uit onderzoek dat het ROA heeft vericht. Uit deze inventarisaties ${ }^{4}$ van arbeidsmarktonderzoek onder afgestudeerden van het hoger onderwijs is gebleken, dat het bestaande onderzoek vaak een incidenteel karakter heeft, niet altijd voldoet aan eisen omtrent representativiteit, consistentie en toegankelijkheid en bovendien onderling niet vergelijkbaar is door van elkaar afwijkende vraagstellingen en coderingen. Met betrekking tot de vraagzijde van de arbeidsmarkt is het beeld zo mogelijk nog somberder. Systematisch onderzoek onder de relevante organisaties en instellingen van een bepaalde sector ontbreekt grotendeels. Dit geldt helaas ook voor de zorgen welzijnssector.

De bestaande onderzoeksinspanningen zouden een geweldige meerwaarde verkrijgen indien de resultaten onderling vergelijkbaar zouden zijn. De hogescholen hebben dan de mogelijkheid om cijfers over de 'eigen' afgestudeerden van een bepaalde studierichting te vergelijken met de landelijke resultaten hierover. Bovendien kunnen dan vergelijkingen worden gemaakt met andere (concurrerende) studierichtingen of tussen verschillende jaargangen. Door het onderzoek onder aanbod- en vraagzijde op de arbeidsmarkt zorgvuldig op elkaar af te stemmen ontstaat een beter inzicht in de aansluitingsproblematiek en worden mogelijkheden geschapen om analyses te maken over de aansluitingsproblematiek op middellange termijn.

Standaardisatie van het arbeidsmarktonderzoek is daarvoor echter een eerste vereiste. Alleen op deze wijze kan een landelijke dataset ontstaan waarmee het mogelijk wordt om ook op het niveau van een branche of een studierichting (statistisch verantwoorde) uitspraken te doen over de aansluitingsproblematiek, de toekomstige arbeidsmarktsituatie te prognosticeren en vergelijkingen te maken tussen bijvoorbeeld verschillende sectoren, regio's en jaargangen.

\section{Instrumenten}

Met het oog op deze standaardisatie van arbeidsmarktonderzoek heeft het ROA een instrument ontwikkeld voor het monitoren (m.a.w. het observeren, volgen en in kaart brengen) door faculteiten van universiteiten en hogescholen van de arbeidsmarktpositie van hun afgestudeerden $^{5}$. Dit instrument, de arbeidsmarktscanner genaamd, omvat een model voor periodiek onderzoek onder zowel de vraagzijde (de werkgevers) als de aanbodzijde (de afgestudeerden zelf) van de arbeidsmarkt. Voor het werkgeversonderzoek wordt periodiek een beperkt, maar representatief panel van bedrijven en instellingen benaderd om de ontwikkeling van het personeelsbestand in kaart te brengen. Voor het aanbodonderzoek worden jaarlijks alle afgestudeerden van een opleiding benaderd.

4. J.W. van Dam en M. Mortier, Inventarisatie van arbeidsmarktonderzoek onder afgestudeerden van het HBO, ROA-W-1990/1; J.W. van Dam, A. de Grip, J.A.M. Heijke, Op zoek naar informatiebronnen over de arbeidsmarktpositie van academici, ROA-W-1988/3, Maastricht.

5. J.W. van Dam, J.A.M. Heijke, G. Ramaekers, Ontwerp van een arbeidsmartkscanner voor academici, ROA-R-1989/3, Maastricht. 
In het kader van het monitoringsysteem HSAO Werkveld is ten behoeve van de zorg- en welzijnssector eveneens een arbeidsmarktscanner ontwikkeld. In samenwerking met het NIZW, COA Groningen en de sector Gedrag en Maatschappij van de RHG heeft het ROA een landelijk toepasbare basisvragenlijst en jaarkaart ontwikkeld waarmee de arbeidsmarktpositie en de ontwikkeling daarin van afgestudeerden van het HSAO in kaart kan worden gebracht. De 'basisvragenlijst' is bestemd voor degenen die circa een jaar daarvoor zijn afgestudeerd. Hiermee worden gegevens verzameld over de opleidingsachtergrond, de arbeidsmarktintrede, de uitgeoefende functies, het bedrijf waar men werkzaam is, alsmede enkele persoonlijke kenmerken. Daarbij komt eveneens een globale evaluatie aan bod van de gevolgde HSAO-opleiding in het licht van de eisen die het werkveld aan de afgestudeerde stelt.

De arbeidsmarkscanner voor het NIZW-project omvat echter meer dan een éénmalige registratie van de bestemming van pas afgestudeerden. Door aan het instrument van de basisvragenlijst eveneens een jaarkaart toe te voegen, waarin veranderingen in de arbeidsmarktpositie worden geregistreerd, is het mogelijk 'longitudinaal' onderzoek te verrichten. Op deze wijze kan van een bepaald cohort (jaargang) van afgestudeerden op termijn de gehele beroepsloopbaan in beeld worden gebracht. Hierdoor wordt het inzicht in de aansluiting tussen de opleiding en de beroepspraktijk belangrijk vergroot. Immers, het oordeel over deze aansluiting kan niet alleen aan de hand van de eerste bestemming van afgestudeerden tot stand komen.

In eerste instantie zijn deze basisvragenlijst en de jaarkaart alleen ontwikkeld ten behoeve van het pilotproject voor het NIZW. In 1991 heeft de HBO-Raad het ROA en het Servicebureau Schoolverlatersinformatie gevraagd om voor de overige sectoren in het HBO een vergelijkbaar onderzoek onder afgestudeerde HBO'ers uit te voeren, waarbij de HSAO-vragenlijst als model zou moeten fungeren. In dit project 'De HBO-Monitor', dat in principe ieder jaar plaatsvindt, kunnen alle hogescholen participeren. De HBO-Raad treedt hierbij op als intermediair.

Inmiddels heeft een eerste rapportage plaatsgevonden over de arbeidsmarktpositie van degenen die in het studiejaar 1989/'90 aan het HSAO zijn afgestudeerd. Doordat naast het NIZW-project, waaraan de RHG deelneemt, in het kader van de HBO-monitor ook de gegevens over afgestudeerden van andere hogescholen uit de sector HSAO bekend zijn, was het mogelijk om ook voor het HSAO een landelijke sectorrapportage te verzorgen, die in september door de HBO-Raad is uitgebracht. Hierin komen, naast een aantal achtergrondkenmerken van de afgestudeerden, ondermeer de arbeidsmarktintrede, de huidige arbeidsmarktpositie en de kenmerken van de huidige functie aan bod. Daarnaast wordt aandacht geschonken aan de aansluiting tussen opleiding en beroep en aan de nascholingsbehoefte. In de landelijke sectorrapportage is bij de beschrijvingen zoveel mogelijk een uitsplitsing gemaakt naar de diverse studierichtingen binnen het HSAO. Naast deze landelijke gegevens hebben de hogescholen in het voorjaar de beschikking gekregen over gegevens omtrent hun 'eigen' afgestudeerden. Doordat deze gegevens vergeleken kunnen worden met de landelijke resultaten, kunnen hieraan tal van arbeidsmarktindicatoren worden ontleend ten behoeve van de eigen kwaliteitsbewaking. De sectorrapportage voor het HSAO is mede mogelijk gemaakt door het Centrum voor Beroeps- en Opleidingsvraagstukken (CBO) van het NIZW. 
Ten behoeve van het werkveld heeft het ROA een pilot-onderzoek onder een panel van werkgevers uit de zorg- en welzijnssector in Noord-Nederland uitgevoerd. Om een beeld te kunnen schetsen van de huidige en toekomstige arbeidsmarktperspectieven van afgestudeerden aan het HSAO dienen namelijk de ontwikkelingen aan zowel de aanbod-, als vraagzijde van de arbeidsmarkt te worden geïnventariseerd. In paragraaf 1.2. wordt verder ingegaan op de opzet van het werkgeversonderzoek.

Bes/uit

Naast dit NIZW-project waarin de arbeidsmarktscanner ten behoeve van het onderwijs en werkveld van het HSAO in haar volle breedte wordt ingezet, wordt in Nederland inmiddels een aantal vergelijkbare projecten uitgevoerd. Naast de eerder genoemde HBO-monitor kan het zogeheten RUBS-project (Registratie van de Uitstroom en de Bestemming van Schoolverlaters) worden genoemd. Dit project beoogt de arbeidsmarktintrede in kaart te brengen van alle pas afgestudeerden uit zowel het algemeen voortgezet onderwijs als het lager en middelbaar beroepsonderwijs ${ }^{6}$. Het monitoringsysteem voor academici wordt op dit moment integraal toegepast voor afgestudeerden van de Rijksuniversiteit Limburg ${ }^{7}$. Besprekingen met andere universiteiten zijn gaande om de arbeidsmarktscanner ook daar in te voeren.

Doordat deze onderzoeken in belangrijke mate op elkaar zijn afgestemd, is aan een belangrijke voorwaarde voldaan om de aansluitingsproblematiek tussen onderwijs en arbeid diepgaander te gaan analyseren. De standaardisatie van arbeidsmarktonderzoek onder afgestudeerden kan nu dus eindelijk vruchten gaan afwerpen.

\subsection{Het werkgeversonderzoek}

\subsubsection{Opzet}

Ten behoeve van het regelmatig signaleren van vooral kwantitatieve knelpunten aan de vraagzijde van de arbeidsmarkt in de zorg- en welzijnssector is een instrument ontwikkeld dat het afgelopen jaar als 'proefonderzoek' is uitgevoerd onder zorg- en welzijnsinstellingen in de provincies Groningen, Friesland en Drenthe. Het betreft hier dus een zogenaamd 'pilot' onderzoek.

Het werkgeversonderzoek heeft als doel periodiek kwantitatieve informatie te verzamelen over de huidige en - op korte termijn - te verwachten vraag naar afgestudeerde HSAO' ers en de mate

6. Dit project wordt uitgevoerd door het ROA, het Servicebureau Schoolverlatersinformatie en de COA's in opdracht van het LDC (mede namens het CBA en de ministeries van Onderwijs \& Wetenschappen en van Landbouw, Natuurbehoud \& Visserij) en het landelijk COA-beraad (namens de regionale opdrachtgevers).

7. Voor een verslag van dit onderzoek: zie G.W.M. Ramaekers, J.A.M. Heijke, Arbeidsmarktscanner Rijksuniversiteit Limburg, Afgestudeerden 1986-1989, ROA-R-1991/6, Maastricht. 
waarin de HSAO'ers concurrentie ondervinden van andere categorieën opgeleiden. Bovendien beoogt het werkgeversonderzoek inzicht te bieden in het beleid ten aanzien van werving- en selectie en scholingsmogelijkheden, en in de wijze waarop de werkgevers contacten onderhouden met HSAO-opleidingen. Tevens wordt ingegaan op de vraag welke interne en externe factoren van invloed zijn op de behoefte aan HSAO'ers.

De opzet van het werkgeversonderzoek is zodanig dat de resultaten ervan vergelijkbaar zijn met en complementair zijn aan die uit het onderzoek onder de afgestudeerden. Het werkgeversonderzoek vormt daarnaast een schakel tussen de landelijke arbeidsmarktgegevens die het NIZW verzamelt en het regionale WIS-instrument. Het welslagen van het panelonderzoek is uiteraard wel afhankelijk van de wijze waarop en de mate waarin werkgevers personeelsgegevens registreren en bereidheid zijn deze ter beschikking te stellen. Het is daarom van belang dat het werkgeversonderzoek zo wordt opgezet, dat het voor iedere werkgever in de zorg- en welzijnssector aantrekkelijk wordt om hieraan mee te doen.

Mede omdat het hier om een proefonderzoek gaat, zijn de gegevens het afgelopen jaar middels een schriftelijke vragenlijst verzameld. Op termijn is het wellicht mogelijk de werkgevers een (software)produkt, c.q. informatiesysteem aan te bieden, waarmee zij het eigen personeels- en scholingsbeleid goed in de gaten kunnen houden. Een soort van 'human accounting'. Eens per jaar zouden deze werkgevers dan enkele gegevens hieruit ter beschikking kunnen stellen. Een activiteit die tevoren is geprogrammeerd, zodat hiermee weinig tijd gemoeid is. Het leveren van (geaggregeerde) gegevens over het personeelsbestand met behulp van een dergelijk informatiesysteem is wellicht voor de (middel)grote instellingen aantrekkelijker dan het invullen van een vragenlijst. Voor de kleine instellingen kan dan worden volstaan met een vragenlijst die eenvoudiger kan zijn dan degene die het afgelopen jaar is gebruikt.

Het werkgeversonderzoek is in principe opgezet als een zogenaamd 'panelonderzoek'. Hierbij wordt een representatieve groep werkgevers periodiek (jaarlijks) benaderd. Doordat in principe steeds dezelfde groep wordt geënquêteerd ontstaat er een continue informatiestroom die een goed inzicht kan bieden in de ontwikkeling (in bijvoorbeeld de personeelssamenstelling) in instellingen. De reden dat er voor het werkgeversonderzoek niet is gekozen voor periodiek cross-sectioneel onderzoek, is dat men bij cross-sectioneel onderzoek niet kan zien of geconstateerde veranderingen toe te schrijven zijn aan bepaalde trendmatige ontwikkelingen in de sector, dan wel een gevolg zijn van het feit dat de steekproef van werkgevers bij herhaalde metingen steeds anders is. Bij panelonderzoek kan men daarentegen voor iedere werkgever die eerder aan het onderzoek heeft deelgenomen zien welke veranderingen er hebben plaatsgevonden. Het onderzoek in de zorg- en welzijnssector is juist gericht op het in kaart brengen van de ontwikkelingen in de aansluiting tussen de HSAO-opleidingen en het werkveld.

Hoewel het onderzoek niet anoniem plaatsvindt ${ }^{8}$ gaat het ROA zeer zorgvuldig om met de

8. Aangezien in principe bij ieder onderzoek hetzelfde panel van werkgevers wordt benaderd, kan dit onderzoek niet anoniem plaatsvinden. 
verstrekte (soms vertrouwelijke) gegevens. Uiteraard worden aan derden geen gegevens verstrekt over individuele werkgevers. Bovendien wordt over individuele werkgevers niet gerapporteerd of gepubliceerd.

\subsubsection{Instrument}

Hoewel het werkgeversonderzoek op termijn een onderdeel kan vormen van een mini-informatiesysteem voor het personeels- en scholingsbeleid van een werkgever, is ten behoeve van het pilot-onderzoek, zoals gezegd, gebruik gemaakt van een schriftelijke vragenlijst.

In de vragenlijst komen de volgende onderwerpen aan bod:

\section{Kenmerken organisatie}

Deze gegevens hebben ondermeer betrekking op de branche waartoe de organisatie behoort, de belangrijkste diensten, c.q. produkten die de organisatie levert, de doelgroepen en het verzorgingsgebied waarop de organisatie zich richt, het oprichtingsjaar, de rechtsvorm, status en de personeelsomvang van de organisatie.

De vragen over de kenmerken van de organisatie worden enerzijds als contrôlevragen gesteld om te bezien of de geselecteerde werkgever ook feitelijk tot de zorg- en welzijnssector behoort. Anderzijds om nader inzicht te krijgen in het soort organisatie dat is benaderd. Deze kenmerken worden als achtergrondvariabelen gebruikt bij de analyses.

\section{Omvang activiteiten}

Dit vragenblok gaat in op de wijze waarop de organisatie wordt gefinancierd en gestructureerd, de totale bruto loonsom en andere indicatoren die inzicht bieden in de omvang van de activiteiten die de organisatie onderneemt.

Deze vragen hebben aan de ene kant dezelfde functies als de vragen over de kenmerken van de organisatie. Aan de andere kant worden deze vragen ook gesteld om het belang van een bepaalde organisatie te bepalen voor de sector. Daarnaast geven de antwoorden op deze vragen inzicht in de dynamiek van de organisatie en kunnen een aantal vragen op termijn worden betrokken bij het formuleren van prognoses over de verwachte werkgelegenheidsontwikkelingen in de sector zorg en welzijn.

\section{Samenstelling personeel in sociaal-agogische functies}

Hierbij gaat het enerzijds om de huidige samenstelling van een aantal 'typische' HSAO-beroepen en anderzijds om de instroom en uitstroom in die beroepen in het afgelopen jaar. De volgende beroepsgroepen zouden 'typisch' voor het HSAO genoemd kunnen worden:

- maatschappelijk werkers; 
- sociaal-pedagogische hulpverleners;

- cultureel werkers;

- personeelswerkers;

- beleidsmedewerkers zorg en welzijn;

- leidinggevenden zorg en welzijn.

Voor iedere HSAO-beroepsgroep geven de werkgevers aan hoeveel mannen en vrouwen er in een bepaalde leeftijdscategorie zijn vertegenwoordigd. Dit wordt ingevuld voor degenen die in een bepaald jaar de organisatie zijn binnengekomen, voor de personen die de organisatie hebben verlaten en voor het totaal aantal medewerkers aan het einde van het jaar. Op deze wijze kan men zien of het aantal personen dat in een HSAO-functie werkzaam is, is gedaald of gestegen en verkrijgt men inzicht in de opbouw en het verloop van het personeelsbestand. Dit is van belang om de toekomstige vervangingsbehoefte van de organisatie te bepalen.

Ten slotte wordt de instroom in een bepaald jaar gedifferentieerd naar opleidingsachtergrond en de mate waarin zij werkervaring hebben en een interne dan wel externe kandidaat waren. Dit zegt iets over (ontwikkelingen in) het wervings- en selectiebeleid van de organisatie. Op deze wijze kan men bovendien tevens concurrentie en verdringing tussen bepaalde categorieën van afgestudeerden in kaart brengen.

Verwachtingen voor komende twee jaar

In dit vragenblok kunnen de werkgevers hun verwachtingen ventileren over een aantal interne en externe veranderingen. Bij interne veranderingen gaat het daarbij om zaken als reorganisatie, automatisering, ontplooien van nieuwe activiteiten, veranderingen van scholings- en personeelsbeleid. Externe veranderingen betreffen bijvoorbeeld bezuinigingen van de overheid, verandering van de doelgroep e.d. De organisatie wordt tevens gevraagd of deze naar verwachting de komende twee jaar betrokken zal raken bij een fusie, overname of verzelfstandiging. Vervolgens mogen de organisaties aangeven welke invloed de door hen genoemde interne en externe veranderingen hebben op de totale werkgelegenheid bij de organisatie en op de werkgelegenheidsontwikkeling voor de HSAO-functies in het bijzonder.

Daarnaast geven de organisaties een schatting van het aantal vacatures dat zij voor iedere HSAO-beroepsgroep de komende twee jaar verwachten. Hierbij maken zij een onderscheid naar vacatures die ontstaan door uitbreiding van de werkgelegenheid en vacatures die zullen voortvloeien uit de (verwachte) vervanging van werknemers ten gevolge van pensionering, VUT, vertrek naar een andere organisatie, langdurige ziekte, zwanger- en ouderschapsverlof e.d.

Hoewel dit vragenblok op zich veel relevante informatie oplevert over de arbeidsmarktperspectieven van afgestudeerde HSAO'ers dient men zich wel te realiseren dat het hier gaat om uitspraken van de werkgevers zelf en dus subjectieve informatie betreft. Men kan niet vooraf zeggen dat de effecten van 'doemdenken' en 'wishful thinking' elkaar geheel compenseren. 
Daarom is het ook belangrijk dat deze subjectieve informatie kan worden aangevuld met objectieve informatie. Uit de vragen over onder andere de personeelssamenstelling van de organisatie kunnen, aangevuld met landelijke gegevens, cijfers worden gedestilleerd om op meer objectieve basis perspectieven voor afgestudeerde HSAO'ers te formuleren. Op termijn is het ook mogelijk om meer specifieke trends in de regionale werkgelegenheidsontwikkeling te schatten.

\section{Scholingsbeleid}

Zoals gezegd, is er door de maatschappelijke ontwikkelingen op economisch, technologisch, politiek-bestuurlijk en sociaal-cultureel terrein, alsmede een aantal ingrijpende organisatorische veranderingen in de zorg- en welzijnssector, sprake van een sterke dynamiek in de beroepsuitoefening en het werkveld. Deze zullen grote gevolgen hebben voor de huidige èn toekomstige beroepsbeoefenaren. De kwalitatieve aansluiting tussen opleiding en beroepenveld kan door deze ontwikkelingen onder druk komen te staan. Nascholing wordt in dit kader dan ook steeds belangrijker. Met het oog hierop is de organisaties gevraagd een aantal gegevens over hun (eventuele) scholingsbeleid aan te geven ten aanzien van het personeel dat in de HSAOberoepsgroepen werkzaam is. Vragen zijn gesteld over het aantal deelnemers, de totale gederfde werktijd hierbij en de totale scholingskosten voor interne en externe opleidingen. Daarnaast hebben de werkgevers aangegeven wat de twee voornaamste doelen waren om het sociaal-agogisch personeel aan cursussen te laten deelnemen.

\section{Contact met HSAO-opleidingen}

De organisaties hebben laten weten of zij met het HSAO in de regio contact onderhouden en hebben tevens aangegeven welk soort contacten met het HSAO zij van belang achten voor hun organisatie. Deze (mogelijke) contacten lopen uiteen van stages door studenten en docenten van het HSAO, werving en selectie van afgestudeerden via het HSAO en het beschikbaarstellen van werknemers (als gastdocent) en apparatuur of ruimte aan het HSAO tot bijscholingsactiviteiten door het HSAO en contractonderzoek door studenten en/of docenten van het HSAO. Voor het verbeteren van de aansluiting tussen het HSAO en het werkveld is het natuurlijk van belang dat organisaties uit de zorg- en welzijnssector regelmatig contact hebben met vertegenwoordigers van het HSAO.

\section{Resultaten onderzoek}

De organisaties hebben kunnen laten weten of zij prijs stellen op een samenvatting van de resultaten van dit onderzoek en of zij betrokken willen worden bij een regionale voorziening waarin de resultaten van alle instrumenten van het monitoringsysteem worden ondergebracht. Hierbij zouden zowel de werkgevers als de opleidingen zijn betrokken met als doel de aansluiting tussen het HSAO en de zorg- en welzijnssector te optimaliseren. Voordat men een dergelijk platform gaat opzetten, moet men eerst nagaan of zoiets een behoorlijk draagvlak heeft. 
De organisaties hebben voor ieder blok aangegeven of de beantwoording van de vragen gebaseerd is op (nauwkeurige) schattingen of dat hierbij gebruik is gemaakt van zogenaamde 'harde cijfers' uit jaarverslagen, een personeelsinformatiesysteem e.d. Dit geeft inzicht in de marge die moet worden gehanteerd bij het interpreteren van de uitkomsten en de mate waarin organisaties in de zorg- en welzijnssector in staat zijn dergelijke kerngegevens te verstrekken.

De gevraagde gegevens hebben over het algemeen betrekking op 1991. Bij de vragen naar de omvang van de activiteiten van de instellingen, gemeten in budget, bruto loonsom en door hen zelf aangegeven meeteenheden, gaat het om de jaren 1990, 1991 en 1992. De verwachtingen over de werkgelegenheidsontwikkeling en vacaturevervulling betreffen de jaren 1992 en 1993. Bovendien hebben de gegevens in principe betrekking op de aangeschreven vestiging van de organisatie. Indien de hoofdvestiging van een organisatie is aangeschreven, dan kunnen de gegevens eveneens de aangesloten nevenvestigingen betreffen.

\subsection{Leeswijzer}

Hoofdstuk 2 doet verslag van de wijze waarop de werkgevers voor dit pilot-onderzoek zijn geselecteerd en de wijze waarop de dataverzameling heeft plaatsgevonden. In dit hoofdstuk wordt eveneens de respons van de werkgevers behandeld. In hoofdstuk 3 volgt een beschrijving van een aantal kenmerken van de benaderde werkgevers en wordt een indicatie gegeven van de omvang van de activiteiten die zij in de zorg- en welzijnssector ondernemen. Hoofdstuk 4 gaat nader in op de omvang en samenstelling van het personeel dat in sociaal-agogische functies werkzaam is, evenals op de ontwikkelingen hierin. Hoofdstuk 5 behandelt de toekomstige behoefte aan sociaal-agogisch personeel, waarbij zowel een eventuele uitbreiding als mogelijke vervanging van het sociaal-agogisch personeel een rol speelt. Het hoofdstuk beoogt tevens inzicht te bieden in het arbeidsmarktperspectief voor toekomstig sociaal-agogisch personeel. In hoofdstuk 6 wordt de omvang van scholing van sociaal-agogisch personeel in aantallen deelnemers en cursusdagen aangegeven, alsmede de kosten die hiermee zijn gemoeid. De redenen waarom werkgevers hun sociaal-agogisch personeel aanvullende scholing bieden worden hier eveneens opgesomd. Hoofdstuk 7 behandelt de contacten tussen het HSAO en het werkveld. Enerzijds wordt nagegaan of de organisatie reeds contact onderhoudt met het HSAO en welke soort contacten zij voor hun organisatie van belang achten. Anderzijds wordt de werkgevers gevraagd of zij prijs stellen op een regionale voorziening waarin de resultaten van het gehele monitoringsysteem worden ondergebracht en waarbij zowel de werkgevers als de opleidingen zijn betrokken met als doel de aansluiting tussen het HSAO en de zorg- en welzijnssector verder te verbeteren. In hoofdstuk 8 worden de belangrijkste conclusies samengevat. Daarbij dient bedacht te worden dat de gepresenteerde gegevens betrekking hebben op een qua omvang beperkt- pilot-onderzoek en derhalve vooral een illustratieve waarde bezitten. Het gaat er vooral om aan te geven wat de mogelijkheden zijn van dit type onderzoek. Daarom worden naast de belangrijkste conclusies tevens een aantal aanbevelingen geformuleerd die voortvloeien uit een evaluatie van de uitvoering en resultaten van dit pilot-onderzoek. 


\section{DATAVERZAMELING EN RESPONS}

\subsection{Selectie en steekproef werkgevers}

In overleg met de leden van de projectadviesgroep en het projectteam is in eerste instantie het steekproefkader vastgesteld. Daarbij is tevens nagegaan hoeveel instellingen uit bepaalde branches van de zorg- en welzijnssector nodig zijn om het te selecteren panel representatief te laten zijn voor de zorg- en welzijnssector in Noord-Nederland ${ }^{9}$. In principe kan dit steekproefkader ook gebruikt worden voor de herweging achteraf om te corrigeren voor onder- of oververtegenwoordiging van bepaalde subcategorieën in de respons. Aangezien het hier gaat om een relatief klein proefonderzoek is een dergelijke weging hier overigens achterwege gelaten. In paragraaf 2.2. wordt voor de onderscheiden branches in de zorg- en welzijnssector de respons aangegeven.

Met behulp van gegevens over welzijnsorganisaties uit het Juliana- en FIRA-bestand van het NIZW, de namen en adressen van instellingen die bij de Nederlandse Ziekenhuisfederatie (NZF), Vereniging van Nederlandse Bejaardenoorden (VNB) of provinciale kindercentra zijn aangesloten en aanvullende gegevens over de ((semi)murale) jeugdhulpverlening is een steekproef van circa 200 organisaties getrokken die zijn gevestigd in Groningen, Friesland of Drenthe. Daarnaast zijn 50 grote profit- en non-profit organisaties buiten de zorg- en welzijnssector benaderd, omdat afgestudeerden van de hogere sociaal-agogische studierichting Personeel \& Arbeid ook bij grote organisaties buiten de sector zorg- en welzijn werkzaam zijn.

Het werkgeversonderzoek is immers, zoals gezegd, complementair aan het onderzoek onder de afgestudeerden van het HSAO. Het panel betreft derhalve niet alleen zorg- en welzijnsinstellingen in strikte zin, maar ook andere instellingen waar veel mensen in sociaal-agogische functies werkzaam (kunnen) zijn. Hierbij kan men bijvoorbeeld denken aan raden voor de kinderbescherming, huizen van bewaring en rijksinrichtingen voor ter beschikking gestelden, sociale diensten van gemeenten en arbeidsbemiddelingsinstanties.

Uit de resultaten van de HBO-monitor 1991 (Van de Loo, Ramaekers en Van der Velden, 1992) blijkt dat ongeveer 30\% van alle HSAO'ers die in 1989/' 90 in Nederland zijn afgestudeerd in zorginstellingen werkzaam is, $40 \%$ in welzijnsorganisaties en $15 \%$ in één van de hierboven genoemde non-profit organisaties. Slechts $15 \%$ van de afgestudeerden werkt in een branche die niet is vertegenwoordigd in het panel van de 'zorg en welzijnssector'. Van de afgestudeerden van de studierichting Personeel \& Arbeid heeft bijna $40 \%$ een baan in het bedrijfsleven. Vandaar dat voor deze groep ook werkgevers buiten de non-profitsector zijn benaderd.

Aangezien het pilot-onderzoek in eerste instantie is bedoeld om de arbeidsmarkt in de zorg- en welzijnssector zelf in kaart te brengen, worden de resultaten van de organisaties die uits/uitend

9. Bijlage 1 bevat de lijst met de onderscheiden branches. 
personele functies bij de opgave van sociaal-agogische formatieplaatsen hebben gemeld niet in dit rapport gepresenteerd. De benaderde organisaties die - eventueel naast personele functies ook - andere HSAO-functies, zoals maatschappelijk werkers, sociaal-pedagogische hulpverleners en cultureel werkers, hebben opgegeven, worden voor dit onderzoek dus tot de zorg- en welzijnssector gerekend. In bijlage 3 is overigens wel aangegeven hoeveel personele functies bij deze - vaak grote - organisaties buiten de zorg- en welzijnssector worden vervuld.

\subsection{Dataverzameling en respons}

Begin maart 1992 is de vragenlijst toegestuurd naar het 'hoofd personeelszaken' van de organisatie. In een kleine organisatie betreft dat over het algemeen de directie van de organisatie. In het begeleidend schrijven vanuit het NIZW is het doel en de inhoud van het monitoringsysteem en het pilot-onderzoek onder werkgevers kort uiteengezet. Voor een nadere toelichting van het project werd verwezen naar een bijgevoegde nieuwsbrief en een aantal projectmedewerkers. De vragenlijst was bovendien voorzien van enkele instructies voor het invullen van de vragenlijst. $\mathrm{Na}$ circa anderhalve maand is in overleg met de projectadviesgroep besloten de organisaties die nog niet hadden gereageerd telefonisch opnieuw te benaderen om te vragen of zij alsnog zouden willen deelnemen aan het onderzoek. Werkgevers die tijdens dit telefoongesprek lieten weten de vragenlijst alsnog ingevuld te retourneren zijn begin juni opnieuw telefonisch benaderd indien hun vragenlijst nog niet was gearriveerd. In tabel 2.1. wordt aangegeven wat het resultaat is geweest van de dataverzameling.

Tabel 2.1. Resultaat dataverzameling werkgeversonderzoek zorg- en welzijn

- fusie

- organisatie onbereikbaar

- geadresseerde onbereikbaar

- geen deelname; vrijwilligers

- geen deelname; geen sociaal-agogisch personeel

- expliciete schriftelijke weigering

- expliciete telefonische weigering

- non-respons

Respons (vragenlijst ingevuld geretourneerd), 69

waarvan:

- vrijwilligersorganisatie

- andere regio

- geen sociaal-agogisch personeel

- in onderzoeksbestand zorg en welzijn

Een kwart van de aangeschreven (personen in) de organisaties bleek onbereikbaar: of de organisatie bleek niet meer op (het opgegeven adres) te bestaan of was herhaaldelijk telefonisch onbereikbaar, of degene die de vragenlijst zou moeten invullen kon men door ziekte of 
langdurige afwezigheid en soms door een overvolle agenda niet bereiken. Daarnaast bleken inmiddels zeven organisaties te zijn gefuseerd met een andere organisatie uit de steekproef.

Ongeveer $10 \%$ van de aangeschreven organisaties bleek geen (sociaal-agogische) beroepskrachten in dienst te hebben. Zeven van deze 21 organisaties hebben de vragenlijst dan ook niet ingevuld geretourneerd. In een enkel geval was er wel sociaal-agogisch personeel bij de instelling werkzaam, maar dit werd dan vanuit de gemeente gedetacheerd naar de instelling. De betreffende gemeente had deze mensen dan in dienst. Om dubbeltellingen te voorkómen zijn deze organisaties niet in het onderzoeksbestand opgenomen.

Ruim $15 \%$ van de benaderde instellingen weigerden schriftelijk dan wel telefonisch expliciet hun medewerking aan het onderzoek. Drukte op het werk, c.q. het hebben van andere prioriteiten bleek de belangrijkste reden om van deelname af te zien. Daarnaast werden nog vaak de volgende redenen genoemd: organisatie ziet geen belang in het onderzoek voor de eigen organisatie, de vragenlijst bevat te veel vragen of zijn niet relevant voor de organisatie, algemene enquêtemoeheid, organisatie behoort niet tot zorg- en welzijnssector of heeft geen (sociaal-agogische) beroepskrachten en/of hoger sociaal-agogisch opgeleiden in dienst. Een deel van de 'weigeraars' gaf aan dat personeelszaken in een andere vestiging worden afgehandeld en een tweetal instellingen liet weten alleen deel te nemen aan enquêtes die onder supervisie van het NZF staan.

Meer dan de helft van de 38 organisaties die tot de categorie 'non-respons' behoren heeft overigens tijdens de eerste telefonische ronde laten weten in principe bereid te zijn de vragenlijst in te vullen. Mogelijk zijn tijdens het invullen een aantal organisaties alsnog afgehaakt. Bij de dataverzameling bleek dat juist grote organisaties ${ }^{10}$ regelmatig moeite hebben met het invullen van de vragenlijst. Opvallend vaak bleken deze (grote) organisaties geen personeelsinformatiesysteem te hebben waaraan zij gemakkelijk gegevens kunnen ontlenen over bijvoorbeeld de leeftijdsopbouw, de scholing of de in- en uittrede van het personeelsbestand. Voor kleine organisaties is de vragenlijst momenteel wellicht te uitgebreid, maar is relatief gemakkelijk in te vullen, daar het hoofd van de organisatie de medewerkers regelmatig ziet.

Ten slotte heeft een organisatie de vragenlijst doorgestuurd naar een zusterorganisatie buiten Noord-Nederland die de vragenlijst ingevuld heeft geretourneerd. Aangezien het werkgeversonderzoek alleen betrekking heeft op de drie noordelijke provincies is de vragenlijst van deze zusterorganisatie niet opgenomen in het onderzoeksbestand.

Het onderzoeksbestand bestaat uiteindelijk uit 55 zorg- en welzijnsinstellingen.

Het responspercentage is berekend door de categorie 'respons' uit tabel 2.1. te delen door het aantal uitgezette vragenlijsten minus degenen die onbereikbaar bleken en de organisaties die inmiddels zijn gefuseerd met andere organisaties uit de steekproef. Er bleken nogal wat

10. Het gaat bijvoorbeeld om ziekenhuizen, gemeenten e.d. 
organisaties onbereikbaar door ziekte of afwezigheid van de aangeschrevenen (directie of hoofd personeelszaken). En in met name de welzijnssector was een behoorlijk aantal - vooral kleine organisaties onbereikbaar, doordat deze inmiddels waren verhuisd, opgeheven of gefuseerd. Het is reëel om deze organisaties buiten beschouwing te laten bij de berekening van het responspercentage. Gezien de samenstelling van met name de welzijnssector en de mogelijke datering van het gebruikte adressenbestand was al op voorhand rekening gehouden met een forse onbereikbaarheid van de organisaties. In de praktijk bleek dit dus inderdaad het geval te zijn. In tabel 2.2. valt af te lezen dat de respons $48 \%$ bedraagt voor alle bereikte zorg- en welzijnsinstellingen tezamen. Wanneer niet wordt gecorrigeerd voor onbereikbaarheid blijkt het responspercentage $34 \%$ te zijn. Ook dit laatste responspercentage is voor dit type onderzoek zeker geen lage respons.

Wanneer de responspercentages van de verschillende branches ${ }^{11}$ worden vergeleken dan blijkt het welzijnswerk een iets hoger responspercentage te hebben onder de bereikte organisaties dan de zorginstellingen. Indien niet wordt gecorrigeerd voor onbereikbaarheid is de respons onder de welzijnsorganisaties echter 32\%, terwijl de respons in de zorgsector dan $41 \%$ bedraagt.

Tabel 2.2. Respons zorg- en welzijnsinstellingen, per branche

\begin{tabular}{lcccc}
\hline & Benaderd & Onbereikbaar & Respons & $\%$ Respons \\
\hline Branche & & & & \\
zorginstellingen & 56 & 3 & 23 & $43 \%$ \\
welzijnsorganisaties & 145 & 53 & 46 & $50 \%$ \\
Totaal zorg en welzijn & 201 & 56 & 69 & $48 \%$ \\
\hline
\end{tabular}

In de populatie van benaderde organisaties blijkt het procentuele aandeel van de welzijnssector significant groter te zijn dan in het uiteindelijke onderzoeksbestand (72\% versus $60 \%)$. Voor de zorgsector geldt het omgekeerde: terwijl slechts $28 \%$ van de 200 vragenlijsten naar de zorginstellingen is gegaan, bestaat maar liefst $40 \%$ van het onderzoek uit organisaties die tot de zorgsector behoren. Juist omdat reeds bij voorbaat werd vermoed dat naar verhouding veel organisaties in de welzijnssector onbereikbaar zouden (kunnen) zijn, zijn welzijnsorganisaties vaker benaderd dan gezien hun aandeel in de werkgelegenheid van HSAO'ers nodig zou zijn. Hoewel de respons dus niet een geheel goede afspiegeling vormt van de totaal benaderde groep organisaties, lijken de organisaties die zijn opgenomen in het onderzoeksbestand van deze pilotstudie redelijk respresentatief te zijn voor de (werkgelegenheid van HSAO'ers) in de zorg-en welzijnssector in Noord-Nederland.

11. In bijlage 1 wordt aangegeven hoe de indeling in branches tot stand is gekomen. Daarbij wordt tevens het aantal organisaties uit het onderzoeksbestand vermeld dat tot een bepaalde werksoort wordt gerekend. 


\section{PROFIEL ORGANISATIES IN ZORG- EN WELZIJNSSECTOR}

\subsection{Inleiding}

In de eerste paragraaf van dit hoofdstuk wordt een beeld geschetst van een aantal organisatiekenmerken die de zorg- en welzijnssector typeren. Achtereenvolgens zal worden ingegaan op de branches die kunnen worden onderscheiden, de periode dat de organisatie haar activiteiten ontplooit, het 'afzetgebied', een eventuele fusie, overname of verzelfstandiging, alsmede de rechtsvorm en status van de organisatie.

De tweede paragraaf behandelt de omvang van de organisaties en de jaarlijkse groei hiervan in de periode 1990 - 1992. De werkgevers hebben de omvang van hun organisatie uitgedrukt in het totale budget van de organisatie, de bruto totale loonsom, het aantal werknemers en een door hen zelf gekozen meeteenheid die een goede indicatie geeft van de omvang van de activiteiten die in die periode door de organisatie zijn ondernomen.

Verschillen in kenmerken en de omvang van de zorg- en welzijnsinstellingen kunnen worden benut bij de beschrijving van verschillen tussen de organisaties wat betreft bijvoorbeeld het werving-, selectie- en scholingsbeleid en de verwachtingen omtrent de werkgelegenheidsontwikkeling bij de organisatie.

\subsection{Kenmerken van organisaties in zorg- en welzijnssector}

De zorg- en welzijnssector valt in feite uiteen in zorginstellingen waarbij de totale murale verzorging van mensen centraal staat en welzijnsorganisaties die zijn gericht op het ambulant aanbieden van advies en hulp om het welzijn van (bepaalde groepen) mensen te verbeteren.

Zoals reeds uit tabel 2.3. kon worden geconcludeerd behoort $40 \%$ van de onderzochte werkgevers tot de zorgsector en $60 \%$ tot de welzijnssector. Binnen de zorgsector wordt de helft tot de gezondheidszorg gerekend en de andere helft tot de zogenaamde murale maatschappelijke dienstverlening. Van de welzijnsinstellingen is een kwart bezig met sociaal-cultureel werk, en verleent $45 \%$ ambulante hulp bij allerlei maatschappelijke diensten. Ten slotte betreft $30 \%$ van de onderzochte werkgevers in de welzijnssector een overheidsinstelling.

De reden dat in dit werkgeversonderzoek de resultaten vaak worden onderverdeeld naar de zorg- en welzijnssector heeft niet alleen te maken met het eerder genoemde inhoudelijke verschil, maar tevens met verschillen in een aantal organisatiekenmerken.

Zo kan uit tabel 3.1. worden afgelezen, dat welzijnsorganisaties over het algemeen 'jongere' organisaties zijn dan de zorginstellingen. Terwijl van de zorginstellingen slechts $5 \%$ in 1980 of daarna is opgericht, bestaat van de welzijnsorganisaties de helft pas sinds 1980 . Omgekeerd is bijna tweederde van de zorginstellingen al vóór 1970 actief, terwijl dit slechts voor $16 \%$ van de welzijnsorganisaties geldt. Eénderde van zowel de zorg- als welzijnsorganisaties is in de jaren 
' 70 opgericht.

Bijna de helft van de zorg- en welzijnssector in Noord-Nederland heeft een plaatselijke functie, terwijl ruim éénderde op de gehele provincie is gericht. Bij de welzijnsorganisaties komt echter $61 \%$ van de doelgroepen uit de gemeente of de directe omgeving daarvan, terwijl dit percentage voor de zorginstellingen slechts 27 bedraagt. Zo goed als de helft van de zorginstellingen heeft een provinciale functie. Dit geldt slechts voor ruim een kwart van de welzijnssectoren. Naar verhouding hebben slechts weinig organisaties een landelijke functie. Dit zou mede te maken kunnen hebben met de voor Nederland 'perifere' ligging van de onderzochte organisaties.

Tabel 3.1. Organisatiekenmerken van zorg- en welzijnsinstellingen

\begin{tabular}{|c|c|c|c|c|}
\hline & $\begin{array}{c}\text { Zorg } \\
\%\end{array}$ & $\begin{array}{c}\text { Welzijn } \\
\%\end{array}$ & $\begin{array}{c}\text { Totaal Z } \\
\%\end{array}$ & $\begin{array}{l}\text { Welzijn } \\
\mathrm{N}\end{array}$ \\
\hline \multicolumn{5}{|l|}{ Oprichtingsjaar } \\
\hline$<1950$ & $29 \%$ & $10 \%$ & $18 \%$ & 9 \\
\hline $1950-1959$ & $14 \%$ & $3 \%$ & $8 \%$ & 4 \\
\hline $1960-1969$ & $19 \%$ & $3 \%$ & $10 \%$ & 5 \\
\hline $1970-1979$ & $33 \%$ & $33 \%$ & $33 \%$ & 17 \\
\hline $1980-1989$ & $5 \%$ & $43 \%$ & $27 \%$ & 14 \\
\hline 1990 en later & -- & $7 \%$ & $4 \%$ & 2 \\
\hline \multicolumn{5}{|l|}{ Plaats doelgroepen } \\
\hline gemeente en omstreken & $27 \%$ & $61 \%$ & $47 \%$ & 26 \\
\hline provincie & $46 \%$ & $27 \%$ & $35 \%$ & 19 \\
\hline Noord-Nederland & $14 \%$ & $9 \%$ & $11 \%$ & 6 \\
\hline Nederland & $14 \%$ & $3 \%$ & $7 \%$ & 4 \\
\hline \multicolumn{5}{|l|}{ Rechtsvorm } \\
\hline stichting & $86 \%$ & $69 \%$ & $76 \%$ & 41 \\
\hline vereniging & -- & $6 \%$ & $4 \%$ & 2 \\
\hline publiekrechtelijk orgaan & $14 \%$ & $25 \%$ & $20 \%$ & 11 \\
\hline \multicolumn{5}{|l|}{ Status organisatie } \\
\hline nevenvestiging & $48 \%$ & $21 \%$ & $32 \%$ & 17 \\
\hline hoofdvestiging & $10 \%$ & $30 \%$ & $22 \%$ & 12 \\
\hline zelfst. vestiging & $43 \%$ & $49 \%$ & $46 \%$ & 25 \\
\hline \multicolumn{5}{|l|}{$\begin{array}{l}\text { Verzelfstandiging, } \\
\text { fusie, overname '91 }\end{array}$} \\
\hline ja, fusie & $14 \%$ & $6 \%$ & $9 \%$ & 5 \\
\hline ja, verzelfstandiging & $9 \%$ & $3 \%$ & $6 \%$ & 3 \\
\hline nee, geen reorganisatie & $77 \%$ & $91 \%$ & $85 \%$ & 46 \\
\hline \multicolumn{5}{|l|}{$\begin{array}{l}\text { Verzelfstandiging, } \\
\text { fusie, overname ' } 92 / ' 93\end{array}$} \\
\hline ja, fusie & $33 \%$ & $53 \%$ & $45 \%$ & 23 \\
\hline ja, overname van andere & $5 \%$ & $7 \%$ & $6 \%$ & 3 \\
\hline nee, geen reorganisatie & $62 \%$ & $40 \%$ & $49 \%$ & 25 \\
\hline
\end{tabular}


Ruim driekwart van de organisaties in de zorg-en welzijnssector is een stichting. Bij de welzijnsorganisaties is dit percentage lager dan bij de zorginstellingen. Bij de welzijnsorganisaties gaat het bij een kwart om een publiekrechtelijk orgaan: overheidsinstellingen dus, zoals Diensten Sociale Zaken van gemeenten, provinciale raden voor de kinderbescherming e.d. (zie ook bijlage 1). Het percentage verenigingen is - ook bij de welzijnsorganisaties - erg laag. Dit heeft mede te maken met het feit dat met name verenigingen (voor zover deze al hebben gereageerd) uitsluitend met vrijwilligers werken en dan dus niet zijn opgenomen in het onderzoeksbestand.

Krap de helft van zowel de welzijns- als zorginstellingen geeft op een zelfstandige vestiging te zijn. De zorginstellingen blijken naar verhouding vaker de nevenvestiging van een grotere organisatie te betreffen (48\% versus $21 \%$ ), terwijl het bij $30 \%$ van de onderzochte welzijnsinstellingen om de hoofdvestiging van een grotere organisatie gaat. Indien de onderzochte organisatie een nevenvestiging betreft, dan is bij bijna de helft van deze organisaties de hoofdvestiging in een ander deel van Nederland gevestigd, terwijl bij ruim een derde de hoofdvestiging in dezelfde gemeente als de betreffende organisatie gevestigd is. De hoofdvestigingen van nevenorganisaties in de welzijnsorganisaties zijn vooral in dezelfde gemeente gesitueerd $(57 \%)$ en neveninstellingen in de zorgsector met name buiten Noord-Nederland $(60 \%)$.

In 1991 is het merendeel (85\%) van de organisaties niet bij een fusie, overname of verzelfstandiging betrokken geweest. Welzijnsorganisaties nog minder dan zorginstellingen $191 \%$ versus $77 \%)$. Voor zover een dergelijke reorganisatie zich voordeed ging het vaker om een fusie dan om een verzelfstandiging. Overnames werden niet vermeld, al kan het natuurlijk wel zijn voorgekomen dat een organisatie fuseert met een naar verhouding kleine of juist grote instelling, zodat dat in de praktijk toch vaak als een overname wordt ervaren.

Uiteraard kunnen dergelijke reorganisaties al vóór 1991 hebben plaatsgevonden, maar daar is niet naar gevraagd. Wel hebben de werkgevers aangegeven of zij verwachten in 1992 of 1993 bij een fusie, overname of verzelfstandiging betrokken te raken. In vergelijking met 1991 verwachten veel meer werkgevers met een dergelijke reorganisatie geconfronteerd te worden; $38 \%$ van de zorg- en zelfs $60 \%$ van de welzijnsinstellingen. In vrijwel alle gevallen gaat het daarbij om een fusie.

Ten opzichte van 1991 betekent dit enerzijds dat het aantal reorganisaties toeneemt. Anderzijds dat het in de nabije toekomst met name de welzijnssector is die hiermee wordt geconfronteerd. Bovendien is opmerkelijk dat, anders dan in 1991, geen enkele organisatie verwacht te verzelfstandigen.

Juist bij panelonderzoek kunnen dergelijke reorganisaties problemen opleveren voor de vergelijkbaarheid van de gegevens van een bepaalde organisatie over verschillende jaren. Bij een vergelijking van jaargegevens zal hiermee derhalve rekening moeten worden gehouden. 


\subsection{Omvang van organisaties in zorg- en welzijnssector}

Om enig inzicht te hebben in de omvang en de groei van de zorg- en welzijnssector in NoordNederland zijn de organisaties naar een aantal kengetallen hieromtrent gevraagd. Het gaat hierbij om gegevens die meestal ook zijn terug te vinden in jaarverslagen van organisaties. Aangezien het met name in deze sector kan vóórkomen dat dergelijke gegevens (nog) niet in de jaarverslagen worden verwerkt of deze gegevens over 1991 (en uiteraard over 1992) nog niet beschikbaar zijn, konden de werkgevers ook volstaan met een nauwkeurige schatting. Bijna de helft van de organisaties heeft aangegeven dat de opgegeven gegevens over het budget, de loonsom en het aantal activiteiten op - nauwkeurige - schattingen zijn gebaseerd en niet zijn ontleend aan gegevens uit bijvoorbeeld het jaarverslag. Bij de zorginstellingen heeft $53 \%$ de gevraagde gegevens geschat, bij de welzijnsorganisaties $41 \%$.

Er blijkt - zoals verwacht - een groot verschil te bestaan tussen de zorg- en welzijnsinstellingen wat betreft het aantal personen dat bij de organisatie werkzaam is. Het gaat hier overigens om de personeelsomvang van de vestiging die is geënquêteerd. Bijna de helft van de organisaties in de welzijnssector heeft minder dan 10 werknemers en ruim driekwart heeft minder dan 50 personen in dienst. Bij de onderzochte vestigingen van zorginstellingen komen organisaties met tussen de 10 en 50 werknemers vaak voor $(41 \%)$, evenals organisaties waar tussen de 200 en 500 personen werkzaam zijn (27\%). Zeer kleine, middelgrote en zeer grote organisaties zijn ondervertegenwoordigd.

Tabel 3.2. Personeelsomvang van zorg- en welzijnsinstellingen eind 1991

\begin{tabular}{|c|c|c|c|c|}
\hline & $\begin{array}{c}\text { Zorg } \\
\%\end{array}$ & $\begin{array}{c}\text { Welzijn } \\
\%\end{array}$ & $\begin{array}{c}\text { Totaal } \\
\%\end{array}$ & $\begin{array}{l}\text { Welzijn } \\
N\end{array}$ \\
\hline \multicolumn{5}{|l|}{ Personeelsomvang } \\
\hline 9 personen & $5 \%$ & $48 \%$ & $29 \%$ & 15 \\
\hline 10 - 49 personen & $41 \%$ & $28 \%$ & $33 \%$ & 17 \\
\hline 50 - 99 personen & $14 \%$ & $17 \%$ & $16 \%$ & 8 \\
\hline $100-199$ personen & $5 \%$ & $7 \%$ & $6 \%$ & 3 \\
\hline 200 - 499 personen & $27 \%$ & -- & $12 \%$ & 6 \\
\hline 500 - 999 personen & $5 \%$ & -- & $2 \%$ & 1 \\
\hline 1000 of meer personen & $5 \%$ & -- & $2 \%$ & 1 \\
\hline
\end{tabular}

In overeenstemming met de verschillen in personeelsomvang tussen de zorg- en welzijnssector blijkt uit tabel 3.3. dat het (verwachte) totale budget voor 1992 van de zorginstellingen gemiddeld ruim drie maal zo groot is als het gemiddelde totale budget voor een welzijnsorganisatie in 1992. Desalniettemin heeft een derde van de welzijnsorganisaties en $40 \%$ van de zorginstellingen jaarlijks een budget van tussen de 1 en 5 miljoen gulden ter beschikking. Echter, 37\% van de welzijnsorganisaties heeft in 1992 slechts een budget van minder dan een half miljoen, terwijl geen enkele zorginstelling met een dergelijk budget haar zorgactiviteiten uitvoert. Omgekeerd heeft $45 \%$ van de zorginstellingen een budget dat minimaal 10 miljoen 
gulden bedraagt, terwijl dit slechts voor $13 \%$ van de welzijnsorganisaties geldt.

lets soortgelijks kan worden gezegd over de bruto totale loonsom die de organisaties in 1991 hebben besteed. Zowel in de zorg- als welzijnssector besteed (ruim) een derde deel van de organisaties tussen de 1 en 5 miljoen gulden aan het bruto loon van de werknemers. Een bruto totale loonsom van minimaal 5 miljoen gulden komt in 1991 bij $47 \%$ van de zorginstellingen voor, terwijl dit slechts voor $\mathbf{8 \%}$ van de welzijnsorganisaties geldt. Gemiddeld is de bruto totale loonsom in 1991 voor de zorginstellingen dus beduidend hoger dan die voor de welzijnsorganisaties.

Aangezien de bruto totale loonsom een onderdeel vormt van het totale budget van een organisatie is deze loonsom gemiddeld lager dan het totale budget. Bij de zorginstellingen vormt de bruto totale loonsom ongeveer tweederde deel van het totale budget, terwijl bij de welzijnsorganisaties ongeveer eenderde van het budget aan de bruto loonsom wordt besteed.

Met name bij de welzijnsorganisaties komt het voor dat de vraag over de bruto totale loonsom niet is ingevuld (namelijk bij 27\%). Blijkbaar is een dergelijk kengetal bij deze organisaties momenteel nog niet voldoende bekend en wordt zoiets (nog) niet verwerkt in hun jaarverslagen.

Tabel 3.3. Omvang van zorg- en welzijnsinstellingen, uitgedrukt in totale budget in 1992 en bruto totale loonsom van de organisatie in 1991 ( $x$ f 1.000)

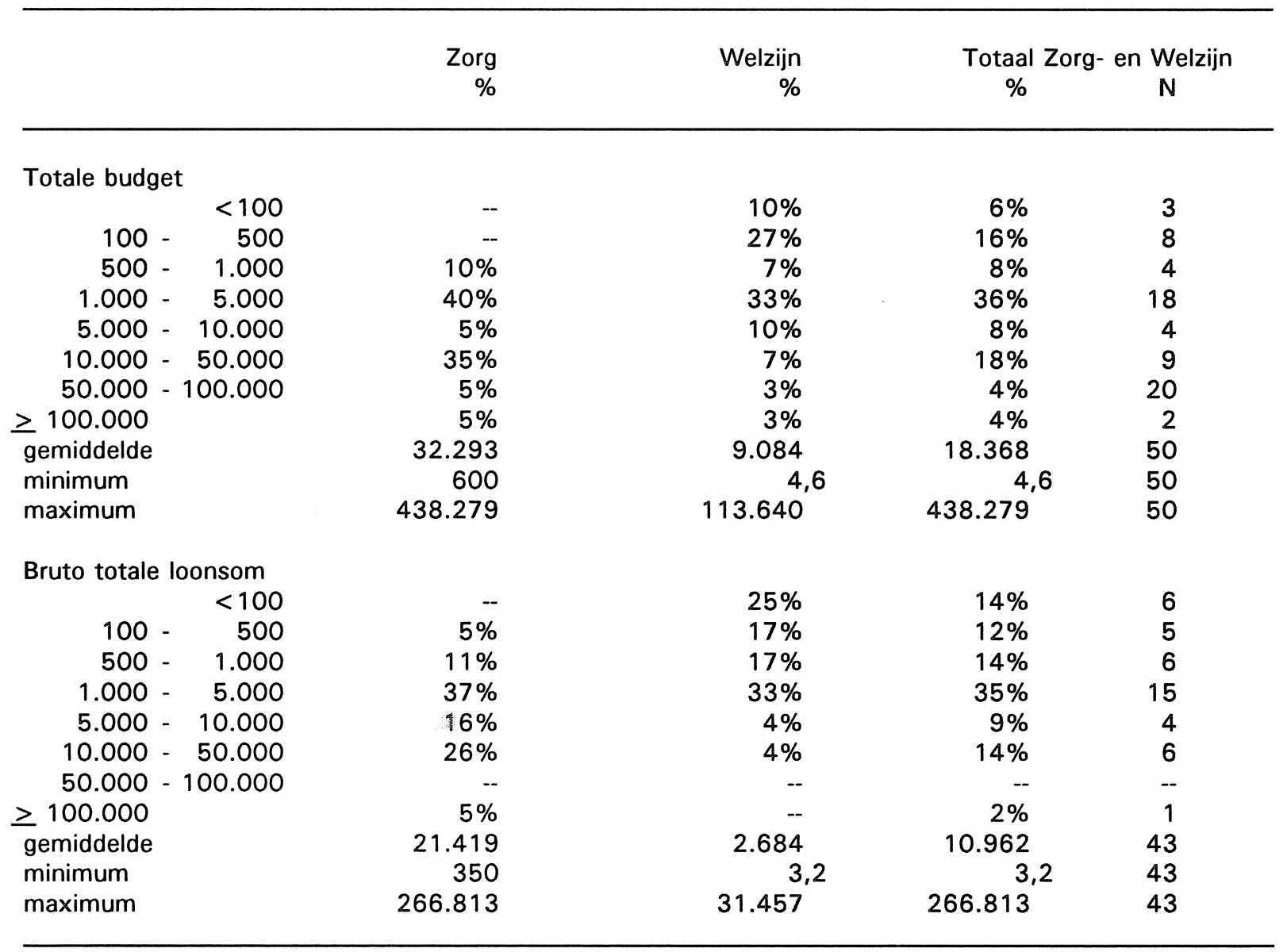


De organisaties is eveneens gevraagd aan te geven welk percentage van hun budget in 1991 werd gefinancieerd door overheidssubsidies. Van alle onderzochte zorg- en welzijnsorganisaties blijkt $60 \%$ voor meer dan $95 \%$ gesubsideerd te zijn; bij de zorginstellingen $70 \%$, bij de welzijnsorganisaties 53\%. Wanneer wordt nagegaan hoeveel organisaties in 1991 voor meer dan $75 \%$ waren gesubsidieerd, dan blijkt dit bij driekwart van de totale zorg- en welzijnssector het geval te zijn. Voor de zorgsector geldt een percentage van 80 , voor de welzijnssector een percentage van 72 .

Tabel 3.4. Jaarlijkse procentuele groei zorg-en welzijnsinstellingen, uitgedrukt in totale budget, bruto totale loonsom en aantal uitgevoerde activiteiten (basisjaar 1990)

$\begin{array}{ccc}\begin{array}{c}\text { Zorg } \\ \%\end{array} & \begin{array}{c}\text { Welzijn } \\ \%\end{array} & \begin{array}{c}\text { Totaal Zorg- en Welzijn } \\ \%\end{array} \\ \mathrm{~N}\end{array}$

Groei budget

$$
\begin{array}{rr}
-5 \% \text { tot } & -5 \% \\
-1 \% \text { tot } & +1 \% \\
+1 \% \text { tot } & +5 \% \\
+5 \% \text { tot } & +10 \% \\
\geq+10 \% &
\end{array}
$$

gewogen gemiddelde ongewogen gemiddelde minimum maximum

Groei loonsom

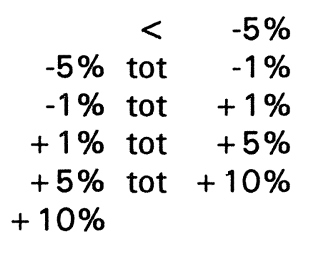

gewogen gemiddelde ongewogen gemiddelde minimum maximum

Groei activiteiten

$$
\begin{array}{rr}
-5 \% \text { tot } & -5 \% \\
-1 \% \text { tot } & +1 \% \\
+1 \% \text { tot } & +5 \% \\
+5 \% \text { tot } & +10 \% \\
\geq+10 \% &
\end{array}
$$

gewogen gemiddelde ongewogen gemiddelde minimum maximum

--
--
$32 \%$
$32 \%$
$32 \%$
$5 \%$
$7 \%$
$3 \%$
$-1 \%$
$10 \%$

$12 \%$
$4 \%$
$46 \%$
$12 \%$
$15 \%$
$12 \%$
$1 \%$
$4 \%$
$-14 \%$
$75 \%$

$\begin{array}{rr}7 \% & 3 \\ 2 \% & 1 \\ 40 \% & 18 \\ 20 \% & 9 \\ 22 \% & 10 \\ 9 \% & 4 \\ & \\ 5 \% & 45 \\ 4 \% & 45 \\ -14 \% & 45 \\ 75 \% & 45\end{array}$

3

18

9

$\begin{array}{rrr}10 \% & 5 \% & 2 \\ -- & 8 \% & 3 \\ 40 \% & 28 \% & 11 \\ 20 \% & 15 \% & 6 \\ 15 \% & 31 \% & 12 \\ 15 \% & 13 \% & 5 \\ -3 \% & 5 \% & 39 \\ 5 \% & 5 \% & 39 \\ -13 \% & -13 \% & 39 \\ 42 \% & 42 \% & 39\end{array}$


In tabel 3.4. wordt de procentuele jaarlijkse groei van het totale budget, de bruto totale loonsom en het aantal ondernomen activiteiten in de zorg- en welzijnssector aangegeven. Voor het berekenen van de jaarlijkse groei van het budget en het aantal uitgevoerde activiteiten is het verschil tussen 1990 en 1992 door tweeën gedeeld. De groei van de bruto totale loonsom betreft het verschil tussen 1990 en 1991. De jaarlijkse groei is ten slotte procentueel gerelateerd aan de omvang in het basisjaar 1990.

Zoals gezegd is het mogelijk dat door een fusie, overname of verzelfstandiging de gegevens die betrekking hebben op meerdere jaren niet goed met elkaar zijn te vergelijken. Daarom is nagegaan of bij de organisaties die in 1991 bij een dergelijke reorganisatie zijn betrokken de gegevens over 1992 belangrijk afwijken van die over 1990. Dit blijkt bij het achttal organisaties waar een dergelijke reorganisatie in 1991 heeft plaatsgevonden niet het geval te zijn. De werkgevers was gevraagd de gegevens over hun eigen vestiging te verschaffen. Blijkbaar is door de reorganisatie de vestiging als zodanig intact gelaten, zodat de gegevens tussen 1990 en 1992 bij deze organisaties wel met elkaar kunnen worden vergeleken.

Uit tabel 3.4. is af te lezen, dat het aantal waarnemingen (N) waarop de cijfers zijn gebaseerd lager zijn dan in tabel 3.3. Dit heeft te maken met het feit, dat de groeicijfers alleen konden worden berekend over de organisaties die voor zowel het basisjaar als het laatste jaar de gegevens hebben ingevuld. Het overgebleven aantal waarnemingen is derhalve zo laag, dat deze groeicijfers slechts als richtinggevend kunnen worden beschouwd. Dat deze desalniettemin toch worden gepresenteerd heeft te maken met het feit dat dit pilot-onderzoek tot doel heeft te laten zien welk soort gegevens het gehouden onderzoek kan opleveren.

Bij $40 \%$ van de zorg- en welzijnsorganisaties is het budget tussen 1990 en 1992 nauwelijks of niet veranderd. Dit schommelt jaarlijks tussen de min en plus $1 \%$. In de zorgsector geldt dit voor $32 \%$ van de instellingen, in de welzijnssector voor $46 \%$. Wanneer rekening wordt gehouden met de (overigens lage) inflatie in deze periode dan betekent dit in feite voor deze indelingen een lichte achteruitgang in het besteedbare budget. Uitschieters in de groei, zowel naar beneden als naar boven, zijn vaker in de welzijnssector dan in de zorgsector te vinden. Bij organisaties met een klein budget, welke verhoudingsgewijs vaker voorkomen in de welzijnssector, kan een wijziging in het budget procentueel gezien namelijk een flinke verandering inhouden.

Wanneer rekening wordt gehouden met de grootte van het budget van een organisatie dan blijkt de gewogen gemiddelde groei voor de zorgsector $7 \%$ te bedragen en slechts $1 \%$ voor de welzijnssector. Het ongewogen gemiddelde van de jaarlijkse procentuele groei van het budget is echter voor de welzijnssector $1 \%$ hoger dan voor de zorgssector (4\% versus $3 \%)$. Deze discrepantie in de groeicijfers vloeit voort uit het feit, dat in de zorgsector het budget van juist enkele zeer grote organisaties in de periode 1990 - 1992 zeer snel is gegroeid. Het omgekeerde is in de welzijnssector het geval.

Wat betreft de jaarlijkse groei van de bruto totale loonsom kan worden opgemerkt, dat in de zorgsector bij bijna de helft van de instellingen de loonsom jaarlijks tussen de $5 \%$ en $10 \%$ is 
gestegen, terwijl in de welzijnssector bij $40 \%$ van de organisaties de loonsom niet of nauwelijks is veranderd.

Uitgaande van het ongewogen gemiddelde zijn er tussen de zorg- en welzijnssector geen verschillen. Wanneer wordt gekeken naar het gewogen gemiddelde dan blijkt de bruto totale loonsom in de zorgsector, evenals bij het budget, een nogal sterke jaarlijkse groei te vertonen, terwijl deze in de welzijnssector zelfs afneemt. Deze schijnbaar tegengestelde ontwikkelingen hebben wederom te maken met het feit dat de afname van de bruto totale loonsom zich met name bij de grote welzijnsinstellingen heeft afgespeeld.

Ten slotte mochten de werkgevers de omvang van de organisatie ook typeren met een door hen zelf aangegeven meeteenheid. In de zorgsector worden vaak eenheden genoemd zoals het aantal ligdagen, het aantal bedden e.d., terwijl in de welzijnssector vaak eenheden als het aantal deelnemers of het aantal behandelingen worden gehanteerd. Juist omdat aan de hand van deze door hen zelf opgegeven meeteenheid omtrent het aantal uitgevoerde activiteiten eigenlijk het beste de groei van de organisatie kan worden afgelezen, is het jammer dat bijna de helft van de onderzochte organisaties deze vraag niet heeft ingevuld. Immers, bij de groei van het totale budget en de bruto totale loonsom spelen zaken als inflatie en loonontwikkelingen een verstorende rol.

Uit tabel 3.4. blijkt dat bij ruim de helft van de zorginstellingen het aantal activiteiten tussen 1990 en 1992 jaarlijks is veranderd, terwijl bij de welzijnsorganisaties ruim een derde haar activiteiten jaarlijks met meer dan $10 \%$ heeft zien groeien. Ook dit vloeit deels voort uit het kleine absolute aantal meeteenheden dat de welzijnsorganisaties hebben genoemd.

Het zou aardig zijn geweest om na te gaan of de arbeidsproduktiviteit de laatste jaren is gestegen. Helaas is niet naar het exacte aantal werknemers in de organisatie gevraagd, doch hebben de werkgevers aangegeven tot welke grootteklasse de organisatie behoort. In een eventueel vervolgonderzoek zal hiermee rekening worden gehouden.

Om een eventuele dynamiek in de organisatie vast te stellen, is de werkgevers gevraagd om aan te geven welk deel van het budget en/of opgegeven meeteenheden in 1991 ten behoeve van nieuwe activiteiten is aangewend. Deze vraag is door zo weinig organisaties beantwoord, dat het weinig zinvol is de resultaten hiervan te bespreken. Een dergelijke vraag lijkt voor deze sector - in de huidige vorm - derhalve niet van toepassing.

\subsection{Conclusies}

In het afgelopen hoofdstuk is naar voren gekomen dat er enkele belangrijke verschillen tussen de zorg- en welzijnsorganisaties bestaan. In vergelijking met de zorginstellingen zijn de welzijnsorganisaties over het algemeen jonger, op gemeentelijk in plaats van provinciaal niveau actief, kleiner naar zowel personeelsomvang, als totale budget en bruto totale loonsom, en gaat het vaker om een hoofdvestiging, terwijl naar verhouding veel onderzochte zorginstellingen 
$-23-$

nevenvestigingen van een grotere organisatie betreffen. Hoewel in 1991 de zorginstellingen vaker bij reorganisaties als fusies en verzelfstandigingen betrokken waren, zijn het voor de periode 1992/'93 vaker de welzijnsorganisaties die een reorganisatie (i.c. fusie) verwachten.

Bij het bespreken van mogelijke discrepanties tussen de zorg- en welzijnssector wat betreft onderwerpen die in de volgende hoofdstukken aan bod komen, kunnen de hiervoor geschetste verschillen tussen beide sectoren een rol spelen. Zo zou het kunnen zijn dat het scholingsbeleid in de zorgsector anders is dan in de welzijnssector. Een dergelijk verschil zou dan voor een belangrijk deel terug kunnen worden gevoerd op het feit dat in de zorgsector vaker grote instellingen voorkomen. 


\section{OMVANG EN SAMENSTELLING PERSONEEL IN SOCIAAL-AGOGISCHE FUNCTIES}

\subsection{Inleiding}

De kern van de enquête onder de werkgevers bestaat uit een aantal vragen over de samenstelling van het personeel in sociaal-agogische functies en de ontwikkelingen hierin in het afgelopen jaar. Het gaat hierbij om kenmerken zoals de leeftijd en het geslacht van de werknemers, evenals om de opleiding en werkervaring van het sociaal-agogisch personeel dat in 1991 is aangenomen. Tevens is naar het aantal werknemers gevraagd dat in 1991 respectievelijk intern dan wel extern voor een sociaal-agogische functie is geworven.

Indien de werkgever deze gegevens niet exact kon invullen, kon de werkgever volstaan met een nauwkeurige schatting. Bijna de helft $(46 \%)$ van de werkgevers heeft aangegeven de antwoorden die betrekking hadden op de vragen over de samenstelling van het personeel in sociaalagogische functies te hebben gebaseerd op (nauwkeurige) schattingen. Bij de zorginstellingen bedroeg dit percentage $63 \%$, bij de welzijnsorganisaties $34 \%$. Bij de over het algemeen kleine welzijnsorganisaties is men bij het invullen - in gedachten - waarschijnlijk 'de deuren langsgegaan'. Bij de grotere zorginstellingen is dit ondoenlijk, terwijl dergelijke gegevens tot op heden nog niet worden verwerkt in (sociale) jaarverslagen of zelfs niet volledig worden opgenomen in een personeelsinformatiesysteem.

Tabel 4.1. Afgestudeerden Maatschappelijk Werk, Sociaal-Pedagogische Hulpverlening, Personeel \& Arbeid en overig HSAO uit 1989/'90 die eind 1991 in een bepaald beroepencluster werkzaam zijn, absoluut en in procenten

\begin{tabular}{|c|c|c|c|c|c|c|c|c|}
\hline & \multirow{2}{*}{\multicolumn{2}{|c|}{ MW }} & \multicolumn{4}{|c|}{ Afgestudeerden } & \multirow[b]{2}{*}{ overig } & \multirow[b]{2}{*}{ HSAO } \\
\hline & & & & $\mathrm{PH}$ & & $\& A$ & & \\
\hline & $\%$ & $N$ & $\%$ & $N$ & $\%$ & $\mathbf{N}$ & $\%$ & $\mathbf{N}$ \\
\hline \multicolumn{9}{|l|}{ Beroepenclusters } \\
\hline maatschappelijk werkers & $62 \%$ & 203 & $6 \%$ & 24 & $2 \%$ & 3 & $5 \%$ & 10 \\
\hline sociaal-pedagogische hulpverleners & $14 \%$ & 46 & $76 \%$ & 331 & $1 \%$ & 1 & $51 \%$ & 98 \\
\hline cultureel werkers & $3 \%$ & 9 & $1 \%$ & 5 & $2 \%$ & 3 & $24 \%$ & 46 \\
\hline personeelswerkers & $1 \%$ & 4 & $1 \%$ & 3 & $69 \%$ & 98 & $2 \%$ & 3 \\
\hline beleidsmedewerkers zorg en welzijn & $2 \%$ & 6 & -- & -- & $2 \%$ & 3 & $2 \%$ & 3 \\
\hline leidinggevenden zorg en welzijn & $5 \%$ & 17 & $7 \%$ & 29 & $6 \%$ & 9 & $3 \%$ & 6 \\
\hline overige beroepenclusters & $13 \%$ & 44 & $10 \%$ & 43 & $18 \%$ & 25 & $14 \%$ & 28 \\
\hline totaal werkende afgestudeerden & $100 \%$ & 329 & $100 \%$ & 435 & $100 \%$ & 142 & $100 \%$ & 194 \\
\hline
\end{tabular}

Voor het beantwoorden van deze vragen zijn de sociaal-agogische beroepen in een zestal beroepenclusters samengevoegd. In bijlage 2 is aangegeven hoe deze clusters zijn samengesteld. De onderscheiden beroepen komen overeen met de beroepen in de vragenlijst die eind 1991 onder de afgestudeerde HSAO'ers uit geheel Nederland is afgenomen. Uit dit onderzoek 
van Van de Loo, Ramaekers en Van der Velden (1992) blijkt dat ruim een jaar na het afstuderen een groot gedeelte van de afgestudeerde HSAO'ers in deze clusters van beroepen is terechtgekomen $^{12}$.

Uit tabel 4.1. kan worden afgelezen dat de onderscheiden HSAO-studierichtingen voor verschillende beroepen opleiden. Bijna tweederde van de afgestudeerden Maatschappelijk Werk is als maatschappelijk werker werkzaam en bij de afgestudeerden van de studierichting SociaalPedagogische hulpverlening heeft zelfs meer dan driekwart een - naar richting - passende baan gevonden. Van de werkende afgestudeerde P\&A-ers heeft daarentegen in $199169 \%$ een baan als personeelwerker, terwijl dit slechts voor een enkeling van de andere werkende afgestudeerde HSAO'ers geldt.

De onderscheiden beroepenclusters bestrijken dus het grootste gedeelte van het beroepenveld van de HSAO'ers. Het afgestudeerdenonderzoek laat zien welke beroepen voor de HSAO'ers, in de eerste jaren van hun loopbaan, het belangrijkste zijn. Met behulp van het werkgeversonderzoek kan juist antwoord worden gegeven op vragen met betrekking tot de concurrentie die HSAO'ers ondervinden van bijvoorbeeld anders opgeleiden (zie paragraaf 4.4.), de mobiliteit in deze beroepen (zie paragraaf 4.3.) en de (toekomstige) arbeidsmarktsituatie voor deze beroepsbeoefenaren (zie hoofdstuk 5).

\subsection{Omvang van personeel in sociaal-agogische functies}

In deze paragraaf wordt voor het totaal van het sociaal-agogisch personeel en voor de naar personeelsomvang belangrijkste drie beroepenclusters, te weten maatschappelijk werkers, sociaal-pedagogische hulpverleners en leidinggevenden zorg en welzijn ${ }^{13}$, een aantal kerncijfers aangegeven, welke tevens zijn onderverdeeld naar zorg- en welzijnssector. In de eerste plaats het aantal (en het percentage) organisaties dat eind 1991 formatieplaatsen (f.t.e.'s $=$ full time equivalenten) ten behoeve van (een bepaalde categorie) sociaal-agogisch personeel in dienst had. Voor deze organisaties is zowel het gemiddelde aantal als de mediaan ${ }^{14}$ van het aantal formatieplaatsen berekend. Daarnaast is het totaal aantal formatieplaatsen dat de organisaties hebben gemeld weergegeven. Vervolgens wordt het gemiddeld en totaal aantal werknemers genoemd. Hierbij gaat het om daadwerkelijk bezette formatieplaatsen, waarbij uitzendkrachten, stagiaires, vrijwilligers, langdurig zieken (meer dan 1 jaar) en mensen die tijdelijk bij de

12. Met name voor degenen die de deeltijdse HSAO-opleidingen hebben gevolgd, geldt dat zij al tijdens hun studie in een sociaal-agogisch beroep werkzaam zijn.

13. De drie andere beroepenclusters bleken naar verhouding erg klein te zijn. In alle onderzochte zorg- en welzijnsorganisaties tezamen bleken er 26,5 f.t.e. te zijn voor cultureel werkers $(20 \%) ; 23,5$ f.t.e. voor personeelswerkers (35\%) en 21,8 voor beleidsmedewerkers zorg en welzijn (31\%). Tussen haakjes staat het percentage organisaties waar dergelijk sociaal-agogisch personeel in 1991 in dienst was. Over deze drie beroepenclusters zal derhalve niet afzonderlijk worden gerapporteerd.

14. De mediaan is de middelste waarneming van een verzameling getallen die naar opklimmende grootte gerangschikt is. 
organisatie zijn gedetacheerd maar door een andere organisatie worden gefinancierd niet tot de werknemers worden gerekend. Deze verhouding is opgenomen als indicatie voor de gemiddelde contractuele arbeidsduur. In verband met het berekenen van deze verhouding zijn in tabel 4.2. alleen de aantallen verdisconteerd voor zover de organisatie zowel het aantal werknemers als het aantal formatieplaatsen per beroepencluster heeft aangegeven.

Gemiddeld is er in een organisatie in de zorgsector drie maal zoveel sociaal-agogisch personeel als in een welzijnsorganisatie $(42,1$ versus 14,0 werknemers $)$. Uitgedrukt in het gemiddelde aantal formatieplaatsen is dit verschil nog groter: 38,5 versus 11,7 f.t.e.

Tabel 4.2. Organisaties, formatieplaatsen en werknemers naar beroepencluster, eind 1991

Zorg Welzijn Totaal Zorg- en Welzijn

Totaal sociaal-agogisch personeel gemiddeld aantal f.t.e.'s totaal aantal f.t.e.'s gemiddeld aantal werknemers totaal aantal werknemers verhouding f.t.e.'s / werknemers

38,5
846
42,1
927
0,91

Beroepenclusters

Maatschappelijk werkers organisaties met MW-ers gemiddeld aantal f.t.e.'s mediaan aantal f.t.e.'s totaal aantal f.t.e.'s gemiddeld aantal werknemers totaal aantal werknemers verhouding f.t.e.'s / werknemers

Sociaal-pedagogische hulpverleners organisaties met SPH-ers gemiddeld aantal f.t.e.'s mediaan aantal f.t.e.'s totaal aantal f.t.e.'s gemiddeld aantal werknemers totaal aantal werknemers verhouding f.t.e.'s / werknemers

Leidinggevenden zorg en welzijn organisaties met LZW-ers gemiddeld aantal f.t.e.'s mediaan aantal f.t.e.'s totaal aantal f.t.e.'s gemiddeld aantal werknemers totaal aantal werknemers verhouding f.t.e.'s / werknemers

$68 \%$
13,8
1,7
193,8
15,6
218
0,89

\section{$95 \%$}

29,3

15,8

497,5

32,1

546

0,91

$95 \%$
6,6
3,1
125,9
6,9
131

0,96

11,7
387,6
14,0
463
0,84

$1.233,6$

25,3

1.390

0,89

$\begin{array}{cc}61 \% & 64 \% \\ 11,5 & 12,5 \\ 7,0 & 3,8 \\ 207,5 & 401,3 \\ 13,4 & 14,3 \\ 241 & 459 \\ 0,86 & 0,87\end{array}$

$15 \%$

21,3

$47 \%$

27,7

18,6

85,2

28,5

114

0,75

15,8

582,7

31,4

660

0,88

$80 \%$

4,7

2,7

2,2

2,8

51,9

177,8

2,9

56

4,9

187

0,95 
Van de in totaal 1390 sociaal-agogische beroepsbeoefenaren ${ }^{15}$ behoort bijna de helft tot de sociaal-pedagogische hulpverleners en een derde tot de maatschappelijk werkers. Daarnaast vervult ruim én op de zeven werknemers een leidinggevende functie in de zorg- en welzijnssector. De verschillen tussen de zorg- en welzijnssector zijn met name bij de maatschappelijk werkers en sociaal-pedagogische hulpverleners te vinden. Terwijl nog geen vierde van alle werknemers in de zorgsector tot de maatschappelijk werkers behoort, heeft ruim de helft van de werknemers in de welzijnssector een functie als maatschappelijk werker. Het omgekeerde verhaal geldt voor de sociaal-pedagogische hulpverleners. Bijna $60 \%$ van de werknemers in de zorgsector heeft een baan als sociaal-pedagogische hulpverlener terwijl dit slechts voor een kwart van de werknemers in de welzijnssector geldt.

Sociaal-pedagogische hulpverleners zijn dus voornamelijk in de zorgsector werkzaam. Terwijl van de zorginstellingen $95 \%$ aangeeft sociaal-pedagogische hulpverleners in dienst te hebben, zijn deze beroepsbeoefenaren slechts bij $15 \%$ van de welzijnsorganisaties in het personeelsbestand opgenomen. Maar de welzijnsorganisaties waar sociaal-pedagogische hulpverleners werkzaam zijn hebben gemiddeld genomen ongeveer evenveel sociaal-pedagogische formatieplaatsen, c.q. werknemers als in de zorgsector. Juist voor de sociaal-pedagogische hulpverleners geldt dat in de zorgsector de gemiddelde contractuele arbeidsduur hoger is dan in de welzijnssector.

Ongeveer tweederde van de zorg- en welzijnsorganisaties heeft minimaal én maatschappelijk werker op de loonlijst staan. Ook wat betreft het gemiddelde aantal formatieplaatsen, c.q. werknemers voor maatschappelijk werkers lijken er geen noemenswaardige verschillen tussen de zorg- en welzijnssector te zijn. Beziet men echter de mediaan van het aantal formatieplaatsen dan blijkt dat deze 1,7 voor de zorginstellingen te bedragen en maar liefst 7 voor de welzijnsorganisaties, terwijl gemiddeld gezien de zorginstellingen meer maatschappelijk werkers hebben dan de welzijnsorganisaties. Deze schijnbare tegenstrijdigheid is het gevolg van het feit dat er van de 15 zorginstellingen 10 organisaties 2 of minder formatieplaatsen voor maatschappelijk werkers hadden, 4 organisaties tussen de 5 en 25 formatieplaatsen meldden en 1 organisatie maar liefst 138 formatieplaatsen voor maatschappelijk werkers had gereserveerd. Bij de welzijnsorganisaties is deze verdeling beduidend minder scheef: 5 van de 20 organisaties had 2 of minder formatieplaatsen voor maatschappelijk werkers, 3 organisaties hadden 2 tot 5 formatieplaatsen, 10 organisaties $5 \mathrm{t} / \mathrm{m} 25$ formatieplaatsen en 2 organisaties $26 \mathrm{t} / \mathrm{m} 40$ formatieplaatsen.

Vier op de vijf organisaties heeft in ieder geval én sociaal-agogische leidinggevende in dienst. Bij de zorginstellingen geldt dit voor $95 \%$ van de organisaties, terwijl dit voor $70 \%$ van de welzijnsorganisaties het geval is. Bovendien werken er in de zorginstellingen in het algemeen meer sociaal-agogische leidinggevenden dan in de welzijnsorganisaties. Gegeven het feit dat de zorginstellingen over het algemeen groter zijn qua personeelsomvang dan de welzijnsorganisaties is dit een logisch resultaat. In vergelijking met de andere beroepenclusters is de verhouding

15. Inclusief de cultureel werkers, personeelswerkers en beleidsmedewerkers zorg en welzijn. 
formatieplaatsen / werknemers erg hoog. Slechts een enkele leidinggevende werkt blijkbaar in deeltijd.

\subsection{Ontwikkelingen in omvang en samenstelling sociaal-agogische functies}

Voor ieder beroepencluster dat in hun organisatie is vertegenwoordigd hebben de werkgevers het aantal mannelijke en vrouwelijke werknemers ingevuld dat in een bepaalde leeftijdsklasse ${ }^{16}$ voorkomt. Zij hebben deze aantallen zowel aangegeven voor het totaal dat eind 1991 in de organisatie werkzaam was, alsmede voor het betreffende aantal werknemers dat gedurende 1991 de organisatie heeft verlaten (= uitstroom), dan wel de organisatie in 1991 is binnengekomen (= instroom).

Met behulp van deze gegevens kan inzicht worden verkregen in de mobiliteit van bepaalde categorieën werknemers en kan de uitbreidings- en vervangingsvraag die de organisaties het afgelopen jaar hebben gekend worden berekend (zie ook hoofdstuk 5). Voor de overzichtelijkheid is het aantal leeftijdsklassen tot een drietal teruggebracht. Uit de literatuur blijkt dat met name vrouwen rond hun dertigste (gedeeltelijk ${ }^{17}$ ) de arbeidsmarkt verlaten om meer tijd te kunnen besteden aan gezinsverzorgende taken. Tussen de 30 en 50 jaar blijft het percentage werkenden vrij stabiel, terwijl na het vijftigste levensjaar het aandeel dat via ondermeer de WAO of VUT de arbeidsmarkt verlaat snel toeneemt. De instroom is enerzijds groot bij de leeftijdsklasse onder de 30 jaar, aangezien schoolverlaters dan de arbeidsmarkt betreden. Vanuit het perspectief van de organisatie is er ook nog een behoorlijke instroom van mensen tussen de 30 en 50 jaar waarvan het merendeel al heeft gewerkt bij een andere organisatie. De instroom van 50-plussers is zeer gering. Vandaar dat deze drie leeftijdsklassen worden onderscheiden. In tabel 4.3. zijn voor het totaal van het sociaal-agogisch personeel en voor de drie belangrijkste beroepenclusters de uitstroom- en instroomgegevens weergegeven, evenals het aantal werknemers dat eind 1991 in een sociaal-agogische functie werkzaam was. De gegevens zijn naar sexe en leeftijd onderverdeeld en gesommeerd over alle onderzochte organisaties.

Aan het begin van 1991 waren er in de onderzochte organisaties $1380(=1415-151+116)$ werknemers in sociaal-agogische functies werkzaam. Het mobiliteitspercentage in 1991 bedroeg 8,4\%; van deze 1380 werknemers zijn namelijk 116 personen uitgestroomd uit de organisatie. Zij hebben of een al dan niet vergelijkbare functie in een andere organisatie aanvaard, of zij zijn al dan niet vrijwillig uit het arbeidsproces getreden. Er blijkt geen noemenswaardig verschil in mobiliteit tussen mannen en vrouwen te bestaan ( 8,5 versus 8,3 procent).

16. Het ging hierbij om de volgende leeftijdsklassen: minder dan 20 jaar, 20-24 jaar, 25-29 jaar, 30-39 jaar, 40-49 jaar, 50-59 jaar en 60 jaar en ouder.

17. In dit onderzoek is alleen een volledige terugtrekking van een werknemer zichtbaar. Indien iemand van een voltijdse dienstbetrekking overschakelt op een deeltijdbaan is dit niet terug te vinden in de uitstroomgegevens. 
Er bestaan wel grote mobiliteitsverschillen tussen de leeftijdsklassen. Terwijl in de jongste leeftijdsklasse het mobiliteitspercentage $12,3 \%$ en in de oudste klasse zelfs $14,5 \%$ bedraagt, is het percentage voor het sociaal-agogisch personeel tussen de 30 en 50 jaar slechts de helft hiervan: namelijk $6,4 \%$. Het hoge percentage bij de ouderen duidt op een forse uittrede uit de arbeidsmarkt. De jongeren zijn daarentegen duidelijk nog op zoek naar een passende baan, waarbij niet uitgesloten moet worden dat dit een gevolg is van onvrijwillig 'job-hoppen' van de ene tijdelijke baan naar de andere tijdelijke baan. Ruim een kwart van de afgestudeerde HSAO'ers blijkt namelijk een tijdelijke baan te hebben. Bij driekwart hiervan gaat het om een contract dat maximaal één jaar duurt (zie Van de Loo, Ramaekers en Van der Velden, 1992).

De instroom van werknemers blijkt de uitstroom te overtreffen (151-116). De werkgelegenheid voor sociaal-agogische functies is in de organisaties met 35 werknemers gegroeid; dat is ten opzichte van het begin van 1991 een groei van ruim 2,5\%. In theorie zou het zo kunnen zijn dat het aantal formatieplaatsen echter gelijk is gebleven, omdat in de organisatie meer mensen in deeltijd zijn gaan werken ${ }^{18}$. Hoewel dit wellicht ook een rol heeft gespeeld, lijkt deze groei van het personeelsbestand in de eerste plaats op een uitbreiding van de werkgelegenheid te duiden.

De overige 116 ingestroomde werknemers dienden ter vervanging van uitgestroomd sociaalagogisch personeel. Deze component van de instroom was dus ruim drie maal zo groot als het deel dat de werkgelegenheidsgroei afdekte. In hoofdstuk 5 zal nader worden ingegaan op deze vervangingsvraag.

Een nadere beschouwing van tabel 4.3. laat zien dat de werkgelegenheidsgroei geheel is toe te schrijven aan een toename van de werkgelegenheid voor vrouwen. Het aantal vrouwen is in 1991 per saldo met 49 werknemers toegenomen, terwijl het aantal mannen in deze periode per saldo met 14 afnam. De vrouwen zijn hun achterstand de laatste jaren snel aan het inlopen, alhoewel (nog steeds) meer dan de helft $(55 \%)$ van het totale sociaal-agogisch personeel uit mannen bestaat. Uitgedrukt in formatieplaatsen zou het verschil tussen mannen en vrouwen nog groter kunnen zijn, aangezien vrouwen vaker in deeltijd werken dan mannen.

Terwijl in de leeftijdsklasse van 50 jaar en ouder vrouwen nog geen $17 \%$ van het sociaalagogisch personeel uitmaken, is het percentage vrouwen in de leeftijdsklasse van 30 tot 50 jaar ruim $41 \%$ en vormen vrouwen in de leeftijdsklasse tot 30 jaar met tweederde de meerderheid. Dit laatste komt overigens aardig overeen met de man-/vrouwverhouding bij de afgestudeerde HSAO'ers uit het studiejaar 1989/'90; het percentage vrouwen bedraagt hier $71 \%$ (zie Van de Loo, Ramaekers en Van der Velden, 1992). Hiermee lijkt de opmars van vrouwen in sociaalagogische functies met name aanbodgestuurd; vrouwen bieden zich veel vaker op de arbeidsmarkt aan, dus is het logisch dat vrouwen vaker worden aangenomen.

18. Bij een jaarlijkse herhaling van het onderzoek kan worden nagegaan of het aantal formatieplaatsen al dan niet gelijk is gebleven. 
$-30-$

Tabel 4.3. Ontwikkelingen in omvang en samenstelling sociaal-agogische functies in 1991

Beroepencluster

Leeftijdsklassen

\section{Uitstroom 1991}

mannen

vrouwen

totaal

$<30$ jaar

Totaal Sociaal-agogisch personeel

Instroom 1991

mannen
vrouwen

\section{2}

23

35

$\geq 50$ jaar

totaal

$$
30 \text { tot } 50 \text { ja }
$$

15

5

21

61

20

20

50

31

2

2

3

53

totaal

70

78

98

Situatie eind 1991

mannen

107

213

vrouwen

570

404

101

20

974

121

778

totaal

$<30$ jaar

Maatschappelijk werkers

Uitstroom 1991

mannen

vrouwen

totaal

0

30 tot 50 jaar

$\geq 50$ jaar

totaal

4
4

11
6
17

4

3

17

7

15

13

Instroom 1991

mannen

2

vrouwen

15

totaal

17

2
12
14

0

1

7

14

Situatie eind 1991

mannen

$$
26
$$

53

216
134

36

278

vrouwen

79

134
350

11

198

totaal

$<30$ jaar

Sociaal-pedagogische hulpverleners

Uitstroom 1991

$\begin{array}{llll}12 & 19 & 7 & 38 \\ 16 & 12 & 1 & 29 \\ 28 & 31 & 8 & 67\end{array}$

vrouwen

28

31

67

Instroom 1991

mannen

$18 \quad 16$

$26 \quad 22$

$16 \quad 2$

vrouwen

44

38

48

totaal

0
2

84

19. Dit totaal wijkt af van het totaal in tabel 4.2. omdat de gegevens in tabel 4.3. betrekking hebben op alle door de organisatie opgegeven werknemers, terwijl tabel 4.2. alleen die werknemers betreft waarvoor de organisatie ook het aantal formatieplaatsen heeft opgegeven. 
Tabel 4.3. Ontwikkelingen in omvang en samenstelling sociaal-agogische functies in 1991 (vervolg)

\begin{tabular}{|c|c|c|c|c|}
\hline & \multicolumn{4}{|c|}{$\begin{array}{l}\text { Beroepencluster } \\
\text { leeftijdsklassen }\end{array}$} \\
\hline & $<30$ jaar & 30 tot 50 jaar & $\geq 50$ jaar & totaal \\
\hline \multirow{3}{*}{$\begin{array}{l}\text { Situatie eind } 1991 \\
\text { mannen } \\
\text { vrouwen } \\
\text { totaal }\end{array}$} & & & & \\
\hline & 72 & 219 & 35 & 326 \\
\hline & $\begin{array}{l}146 \\
218\end{array}$ & $\begin{array}{l}184 \\
403\end{array}$ & $\begin{array}{r}4 \\
39\end{array}$ & $\begin{array}{l}334 \\
660\end{array}$ \\
\hline & \multicolumn{4}{|c|}{ Leidinggevenden zorg en welzijn } \\
\hline \multirow{2}{*}{\multicolumn{5}{|c|}{30 tot 50 jaar }} \\
\hline $\begin{array}{l}\text { Uitstroom } 1991 \\
\text { mannen }\end{array}$ & & 4 & 2 & 7 \\
\hline vrouwen & 1 & 1 & 0 & 2 \\
\hline totaal & 1 & 5 & 3 & 9 \\
\hline \multicolumn{5}{|l|}{ Instroom 1991} \\
\hline mannen & 0 & 6 & 0 & 6 \\
\hline vrouwen & 3 & 6 & 0 & 9 \\
\hline totaal & 3 & 12 & 0 & 15 \\
\hline \multicolumn{5}{|l|}{ Situatie eind 1991} \\
\hline mannen & 4 & 87 & 25 & 116 \\
\hline vrouwen & 7 & 59 & 5 & 71 \\
\hline totaal & 11 & 146 & 30 & 187 \\
\hline
\end{tabular}

Zoals verwacht wordt de - voornamelijk mannelijke - uitstroom in de leeftijdsklasse van 50 jaar en ouder nauwelijks gecompenseerd door instroom, zodat het verschil daar negatief is en de werkgelegenheid, gemeten in het aantal werknemers, in die klasse dus afneemt. Daarentegen neemt het aandeel jongeren tot 30 jaar sterk toe, terwijl in de leeftijdscategorie alleen het aantal vrouwen toeneemt.

Aangezien de totaalcijfers van het sociaal-agogisch personeel sterk worden bepaald door de oververtegenwoordiging van de sociaal-pedagogische hulpverleners, maatschappelijk werkers en leidinggevenden zorg en welzijn zijn deze beroepenclusters ook afzonderlijk geanalyseerd.

In alle onderscheiden beroepenclusters geldt dat in 1991 de instroom de uitstroom van werknemers heeft overtroffen. Dit gold echter het sterkste voor de sociaal-pedagogische hulpverleners en leidinggevenden. Voorts geldt voor de hier gepresenteerde beroepenclusters dat alleen voor vrouwen het verschil tussen in- en uitstroom positief is.

Voorts nog een opmerking over de leeftijdsopbouw van de onderscheiden beroepenclusters. Terwijl circa éénderde van de sociaal-pedagogische hulpverleners jonger dan 30 jaar is, behoort nog geen $6 \%$ van de leidinggevenden tot deze leeftijdsklasse. Van de maatschappelijk werkers is krap $17 \%$ jonger dan 30 jaar. 
In 1991 bleek de mobiliteit bij de leidinggevenden en maatschappelijk werkers met respectievelijk 5,0 en 5,9 procent laag te zijn, hetgeen niet verklaard kan worden door de leeftijdsopbouw.

\subsection{Werving en selectie van sociaal-agogisch personeel}

In deze paragraaf wordt ingegaan op de opleidings- en werkervaringseisen die de werkgevers aan het in 1991 in sociaal-agogische functies aangenomen personeel hebben gesteld. Dit om inzicht te krijgen in de concurrentie tussen verschillende aanbodcategorieën op de arbeidsmarkt voor sociaal-agogische beroepen in de zorg- en welzijnssector. Daarnaast is de werkgevers gevraagd aan te geven of het aangenomen personeel binnen (intern) of buiten (extern) de eigen organisatie is geworven.

In de eerste plaats hebben de werkgevers voor ieder beroepencluster het aantal personen aangegeven dat in 1991 met een bepaalde vooropleiding de organisatie is binnengekomen. Het gaat hier om de hoogst genoten voltooide opleiding van de werknemer. $\mathrm{Er}$ is voor gekozen deze gegevens te vragen met betrekking tot de instroom die in 1991 heeft plaatsgehad. Hieraan kan het beste worden ontleend welke selectie-eisen momenteel, gegeven het aanbod, feitelijk aan bepaalde categorieën van sociaal-agogisch personeel worden gesteld.

Tabel 4.4. Opleidingseisen bij werving en selectie sociaal-agogisch personeel in 1991, naar beroepenclusters, branche en grootte van de organisatie

\begin{tabular}{|c|c|c|c|c|}
\hline & & & eiste ople & \\
\hline & $\begin{array}{r}<\mathrm{HBO} \\
\%\end{array}$ & $\begin{array}{r}\mathrm{HBO} \\
\%\end{array}$ & $\begin{array}{r}>\mathrm{HBO} \\
\%\end{array}$ & $\begin{array}{c}\text { Totaal } \\
\mathrm{N}\end{array}$ \\
\hline Totaal sociaal-agogisch personeel & $40 \%$ & $48 \%$ & $12 \%$ & 123 \\
\hline Beroepenclusters & & & & \\
\hline maatschappelijk werkers & $43 \%$ & $53 \%$ & $3 \%$ & 30 \\
\hline sociaal-pedagogische hulpverleners & $49 \%$ & $49 \%$ & $2 \%$ & 61 \\
\hline leidinggevenden zorg en welzijn & $6 \%$ & $31 \%$ & $63 \%$ & 16 \\
\hline Branche & & & & \\
\hline zorgsector & $42 \%$ & $46 \%$ & $13 \%$ & 79 \\
\hline welzijnssector & $36 \%$ & $52 \%$ & $11 \%$ & 44 \\
\hline $\begin{array}{l}\text { Grootte organisatie } \\
<10 \text { werknemers }\end{array}$ & & & & \\
\hline & $\begin{array}{l}65 \% \\
23 \%\end{array}$ & $\begin{array}{l}35 \% \\
66 \%\end{array}$ & $11 \%$ & $\begin{array}{l}17 \\
35\end{array}$ \\
\hline $\begin{array}{l}10-50 \text { werknemers } \\
\geq 50 \text { werknemers }\end{array}$ & $45 \%$ & $39 \%$ & $15 \%$ & 66 \\
\hline
\end{tabular}

Van het totale aantal dat in 1991 in sociaal-agogische functies is ingestroomd heeft bijna de helft een HBO-opleiding als hoogste opleiding voltooid. De HBO'ers ondervinden echter een geduchte concurrentie van afgestudeerde MBO-ers; twee op de vijf instromers heeft namelijk maximaal een diploma op MBO-niveau behaald. Bij de sociaal-pedagogische hulpverleners worden zelfs evenveel MBO-ers als HBO'ers aangenomen. Uiteraard laat dit onverlet dat in de 
feitelijke beroepsuitoefening de HBO'ers wellicht vaker de banen krijgen met een grotere verantwoordelijkheid en meer doorgroeimogelijkheden. Doch ook hier lijkt een plafond te bestaan. Van de 16 mensen die in 1991 als leidinggevende zijn aangenomen hadden er 5 een opleiding op HBO-niveau en 10 een universitaire of voortgezette HBO-opleiding.

Tussen de twee branches bestaan wat betreft de instroom naar opleidingsniveau vrijwel geen verschillen. De kleine organisaties blijken naar verhouding veel sociaal-agogisch personeel met maximaal een MBO-diploma aan te nemen en hebben in 1991 zelfs niemand in dienst genomen met een voortgezette HBO- of universitaire opleiding. Daarnaast blijken het met name de middelgrote organisaties met tussen de 10 en 50 werknemers te zijn die onder HBO-afgestudeerden werven. Dit zou erop kunnen wijzen dat de kleine organisaties niet voldoende kunnen concurreren met de middelgrote organisaties, zodat zij genoegen moeten nemen met het minder gekwalificeerde aanbod.

Tabel 4.5. Eisen werkervaring bij werving en selectie sociaal-agogisch personeel in 1991, naar beroepenclusters, branche en grootte van de organisatie

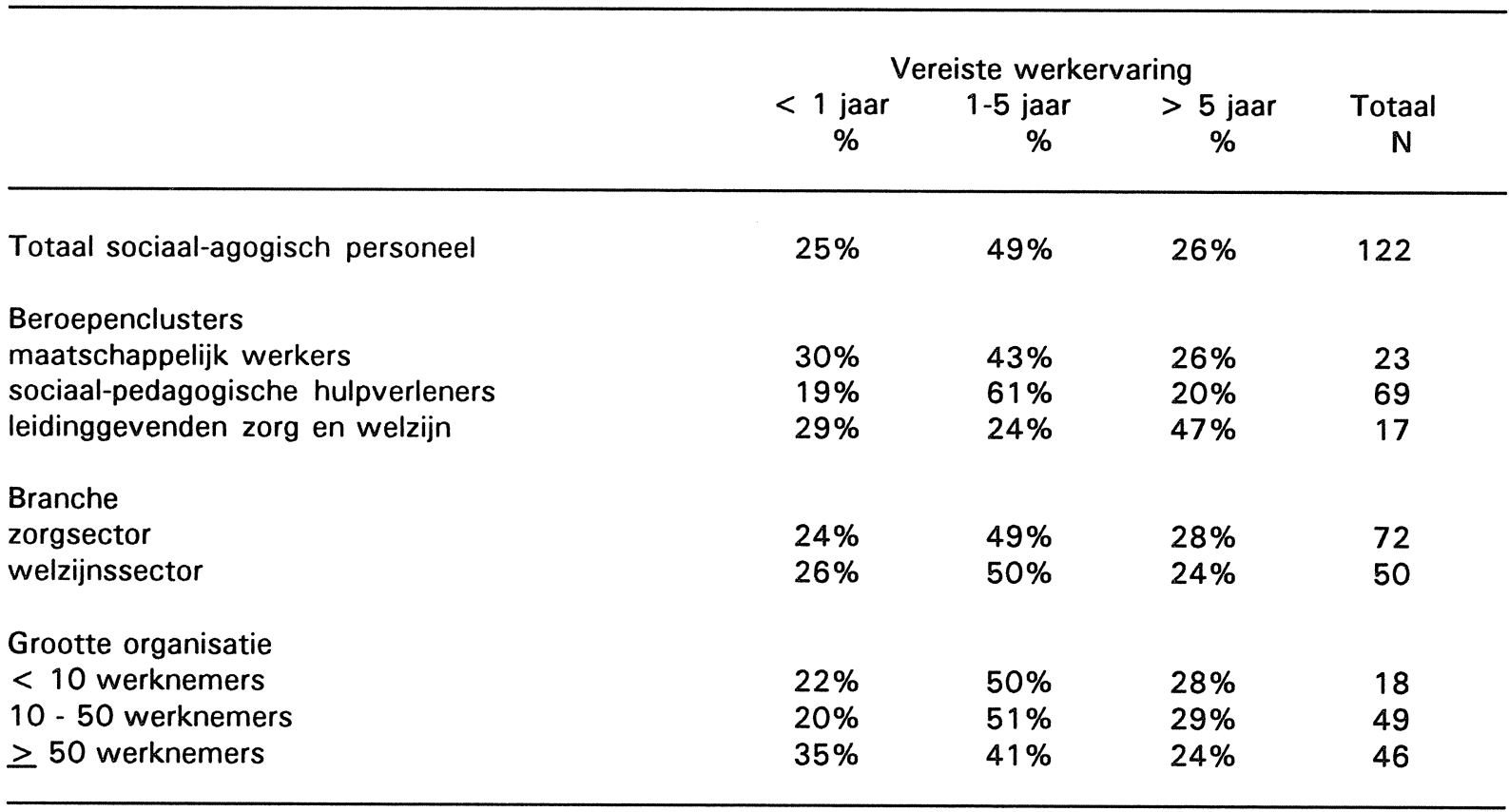

Bij de beantwoording van de vraag naar de hoogst genoten opleiding van de instromers konden de werkgevers uit een elftal opleidingscategorieën kiezen. ${ }^{20}$ In de praktijk bleken deze (afkortingen van) opleidingsnamen bij vele werkgevers niet herkenbaar, gegeven de hoge scores op 'overig MBO/in-service' en 'overig $\mathrm{HBO}^{\prime}{ }^{21}$ Achter deze hoge scores op de 'overig'-

20. Het gaat om de volgende 11 opleidingscategorieën: MAVO/LBO, HAVO/VWO, MDGO, in-service A/B, in-service $\mathrm{Z}$, overig $\mathrm{MBO}$ /in-service, HSAO, HGZO, overig $\mathrm{HBO}$, VO $\mathrm{HBO} / 2 \mathrm{e}$ fase en WO.

21. Bij het MBO bleken 25 van de 44 instromers met ten hoogste een diploma op MBO-niveau onder de categorie 'overig MBO/in-service' te zijn ingevuld, terwijl 21 van de 59 HBO-instromers bij 'overig $\mathrm{HBO}$ ' was ingevuld. 
categorieën bleek echter ook de mening schuil te gaan van een aantal werkgevers die vinden dat het hoger sociaal-agogisch onderwijs de laatste jaren inhoudelijk dusdanig is gewijzigd, dat de afgestudeerden niet meer met dezelfde 'bagage' op de arbeidsmarkt verschijnen. De afgestudeerden van de 'oude' HBO-J(eugdwelzijnswerk) opleidingen zijn volgens deze werkgevers bijvoorbeeld niet te vergelijken met de 'nieuwe' SPH-ers (sociaal-pedagogische hulpverleners). Dit is een indicatie dat hogescholen en werkgevers naar elkaar toe meer duidelijkheid moeten verschaffen over de (gewenste) beroepsprofielen en curricula van de bedoelde opleidingen. Hier zijn (aankomende) studenten, afgestudeerden, hogescholen en werkgevers bij gebaat.

In tabel 4.4. is de instroom weergegeven naar hoogst behaalde opleidingsniveau. Zowel voor de totale instroom van sociaal-agogisch personeel in 1991, als onderverdeeld naar de drie belangrijkste beroepenclusters, branche en personeelsgrootte van de organisatie. Degenen die met een voortgezette $\mathrm{HBO}$ - of $2 \mathrm{e}$ fase $\mathrm{HBO}$-opleiding zijn ingestroomd zijn overigens ingedeeld bij de instromers met een voltooide universitaire opleiding.

Om enig inzicht te kunnen krijgen in hoeverre banen voor sociaal-agogische beroepen beschikbaar zijn voor pas afgestudeerden, is de werkgevers gevraagd voor ieder beroepencluster het aantal personen aan te geven dat in 1991 met een bepaalde mate van werkervaring de organisatie is binnengekomen. Gemiddeld blijkt bijna de helft van het in 1991 aangenomen personeel éen $\mathrm{t} / \mathrm{m}$ vijf jaar werkervaring te hebben. Een kwart van de banen kwam beschikbaar voor mensen die minder dan 1 jaar werkervaring hadden, terwijl een kwart van de vrijgekomen banen is ingevuld door werknemers die meer dan 5 jaar werkervaring hadden. Gegeven het feit dat voor het volgen van een deeltijdopleiding binnen het HSAO de formele eis geldt dat men minimaal 20 uur per week (betaalde of onbetaalde) voor het vakgebied relevant werk verricht, is in 1991 in ieder geval meer dan een kwart van de banen door pas afgestudeerden van de voltijdopleidingen vervuld.

Zoals wellicht verwacht kon worden heeft maar liefst $47 \%$ van de in 1991 ingestroomde leidinggevenden meer dan 5 jaar werkervaring. Bij de sociaal-pedagogische hulpverleners die in 1991 in dienst zijn gekomen van de organisaties is met name het percentage met een middellange werkervaring van tussen de éen en vijf jaar met $61 \%$ relatief hoog.

Tussen de twee branches blijken er zo goed als geen verschillen te bestaan tussen de mate van werkervaring van het in 1991 aangenomen sociaal-agogisch personeel.

De organisaties met minimaal 50 werknemers blijken naar verhouding vaker sociaal-agogisch personeel met minder dan een jaar werkervaring aangesteld te hebben, dan de kleine en middelgrote organisaties. In grotere organisaties kunnen mensen met nauwelijks werkervaring blijkbaar makkelijker worden ingepast, dan in kleine organisaties, waarbij het nieuwe personeel waarschijnlijk direct volledig inzetbaar moet kunnen zijn.

Ten slotte hebben de werkgevers voor ieder beroepencluster het aantal personen aangegeven 
dat in 1991 intern dan wel extern is geworven. Het absolute totale aantal geworven personeel blijkt in tabel 4.6. groter te zijn dan in de twee voorgaande tabellen. De twee voorgaande tabellen hadden namelijk betrekking op het aantal personen dat de organisatie in 1991 is binnengekomen; in feite ging het daar om het extern geworven sociaal-agogisch personeel. Van het intern geworven personeel is de hoogst genoten opleiding en de werkervaring derhalve niet bekend, al zullen de meeste interne kandidaten wel meer dan éen jaar werkervaring hebben. Enerzijds is dit wellicht een omissie, anderzijds is zo wel duidelijker welke eisen de werkgevers aan het aanbod op de (externe) arbeidsmarkt stellen.

In 1991 is tweederde van de vrijgekomen banen voor sociaal-agogisch personeel opgevuld door kandidaten van buiten de eigen organisatie. De sociaal-pedagogische hulpverleners zijn daarentegen relatief vaak binnen de eigen organisatie geworven. De in 1991 aangenomen maatschappelijk werkers en leidinggevenden komen voor het grootste gedeelte via de externe arbeidsmarkt.

Tabel 4.6. Wervingskanaal bij werving sociaal-agogisch personeel in 1991, naar beroepenclusters, branche en grootte van de organisatie

\begin{tabular}{|c|c|c|c|}
\hline & \multicolumn{2}{|c|}{ Werving } & \multirow[b]{2}{*}{$\begin{array}{c}\text { Totaal } \\
\mathrm{N}\end{array}$} \\
\hline & $\begin{array}{c}\text { Intern } \\
\%\end{array}$ & $\begin{array}{c}\text { Extern } \\
\%\end{array}$ & \\
\hline Totaal sociaal-agogisch personeel & $34 \%$ & $66 \%$ & 173 \\
\hline \multicolumn{4}{|l|}{ Beroepenclusters } \\
\hline maatschappelijk werkers & $29 \%$ & $71 \%$ & 48 \\
\hline sociaal-pedagogische hulpverleners & $42 \%$ & $58 \%$ & 84 \\
\hline leidinggevenden zorg en welzijn & $14 \%$ & $86 \%$ & 21 \\
\hline \multicolumn{4}{|l|}{ Branche } \\
\hline zorgsector & $33 \%$ & $67 \%$ & 121 \\
\hline welzijnssector & $37 \%$ & $63 \%$ & 52 \\
\hline \multicolumn{4}{|l|}{ Grootte organisatie } \\
\hline$<10$ werknemers & $63 \%$ & $37 \%$ & 19 \\
\hline $10-50$ werknemers & $25 \%$ & $75 \%$ & 72 \\
\hline$\geq 50$ werknemers & $34 \%$ & $66 \%$ & 73 \\
\hline
\end{tabular}

Ook op dit punt blijken er nauwelijks verschillen te bestaan tussen de zorg- en de welzijnssector. Daarentegen zijn er wel verschillen naar bedrijfsgrootte. Tegen de verwachtingen in blijkt maar liefst tweederde van de kleine organisaties vorig jaar het sociaal-agogisch personeel intern te hebben geworven, terwijl de middelgrote organisaties vaker dan gemiddeld daarentegen juist personeel via de externe arbeidsmarkt hebben aangetrokken. 


\section{TOEKOMSTIGE BEHOEFTE AAN SOCIAAL-AGOGISCH PERSONEEL}

\subsection{Verwachtingen van werkgevers voor 1992 en 1993}

Terwijl de andere hoofdstukken ingaan op kenmerken van de huidige arbeidsmarkt in de zorgen welzijnssector, wordt in dit hoofdstuk juist aandacht besteed aan een aantal toekomstige arbeidsmarktontwikkelingen in deze sector. Immers, voor het goed kunnen (uit)voeren van bijvoorbeeld personeels- en scholingsbeleid is het nodig om inzicht te hebben in de toekomstige vraag naar en aanbod van sociaal-agogische beroepskrachten.

Voor het in kaart brengen van de arbeidsmarktontwikkelingen aan de vraagzijde is de werkgevers dan ook gevraagd hun verwachtingen voor de komende twee jaar uit te spreken met betrekking tot de werkgelegenheidsontwikkeling in de organisatie in het algemeen en ten aanzien van het sociaal-agogisch personeel in het bijzonder. Daarbij konden de werkgevers aangeven of zij de komende twee jaar bij een fusie, overname of verzelfstandiging betrokken zouden zijn en welke externe en interne veranderingen zij in 1992 en 1993 verwachten. Ten slotte hebben de werkgevers een indicatie gegeven van het aantal vacatures dat zij de komende twee jaar bij het sociaal-agogisch personeel verwachten.

Zoals reeds in paragraaf 3.2. ter sprake is gebracht, verwacht ruim de helft van de onderzochte organisaties in 1992 of 1993 bij een fusie of overname betrokken te raken. Bij de zorginstellingen zijn deze percentages echter lager dan bij de welzijnsorganisaties. In de zorgsector verwacht één op de drie instellingen te fuseren en $5 \%$ een andere instelling over te nemen, terwijl in de welzijnssector deze percentages respectievelijk 53 en 7 procent bedragen. Vergeleken met de percentages van organisaties waarbij in 1991 een fusie of overname heeft plaatsgevonden zijn de percentages voor de verwachte reorganisaties erg hoog, hetgeen voor een deel een gevolg zal zijn van het feit dat de verwachtingen voor 1992 en 1993 twee jaren bestrijken, terwijl de vraag over een feitelijk totstandgekomen fusie slechts éen jaar (1991) betreft. Daarnaast is het interessant om bij een vervolgonderzoek na te gaan hoeveel van deze verwachte fusies en overnames uiteindelijk zijn geëffectueerd.

In tabel 5.1. staat aangegeven wat de belangrijkste veranderingen zijn die de werkgevers de komende twee jaar voor hun organisatie verwachten. De werkgevers konden zowel twee externe als twee interne veranderingen invullen.

Een herstructurering van het hulpaanbod en daarmee samenhangend veranderingen in de doelgroep van de organisatie zijn het vaakst door de onderzochte organisaties aangegeven. In de zorgsector vindt deze herstructurering vaak plaats in het kader van de stelselherziening en wordt regelmatig een verschuiving van residentiële en curatieve naar ambulante en preventieve zorg verwacht. In de welzijnssector gaat het meestal om een herstructurering van de plaatselijke of provinciale welzijnsactiviteiten, meestal geïnitieerd vanuit de overheid. Daarnaast worden bezuinigingen of opgelegde budgetteringen door overheden of andere subsidieverschaffers, alsmede fusies en samenwerkingscontracten eveneens vaak genoemd bij de externe veranderin- 
gen. Bijna één op de drie zorginstellingen en meer dan de helft van de welzijnsorganisaties verwacht de komende jaren met van buiten opgelegde bezuinigingen geconfronteerd te worden. Terwijl in de welzijnssector een derde deel van de organisaties een fusie of vergaande samenwerking met een andere organisatie verwacht, geeft nog geen kwart van de zorginstellingen aan bij een dergelijke operatie betrokken te raken. Een verdergaande decentralisatie wordt eveneens door een aantal werkgevers gememoreerd. Mede door de bovengenoemde externe veranderingen verwachten enkele zorginstellingen, dat de concurrentieverhoudingen zullen wijzigen, c.q. verscherpen.

Tabel 5.1. Belangrijkste twee verwachte externe en interne veranderingen voor de organisatie in 1992 en 1993, absoluut (N) en relatief $(\%)^{22}$

\begin{tabular}{|c|c|c|}
\hline Zorg & Welzijn & Totaal Zorg- en Welzijn \\
\hline$\% \quad N$ & $\%$ & $\%$ \\
\hline
\end{tabular}

Soort verandering

Extern

herstructureren hulpaanbod/doelgroep

$\begin{array}{rrrrrr}45 \% & 10 & 36 \% & 12 & 40 \% & 22 \\ 32 \% & 7 & 55 \% & 18 & 45 \% & 25 \\ 23 \% & 5 & 33 \% & 11 & 29 \% & 16 \\ 9 \% & 2 & 9 \% & 3 & 9 \% & 5 \\ 9 \% & 2 & -- & 4 \% & 2 & \\ 5 \% & 1 & -- & 2 \% & 1 & \\ & 27 & & 44 & & 71 \\ & 22 & & 33 & & 55\end{array}$

Totaal externe veranderingen

Totaal organisaties

$27 \%$
$14 \%$
--
$18 \%$
$23 \%$
$23 \%$
--
--
$14 \%$
$14 \%$

Intern

reorganisatie

nieuwe (contract)activiteiten

afstoten activiteiten

verandering taakinhoud, methoden

scholingsbeleid

personeels-/ziekteverzuimbeleid

uitbreiding personeel

meer overleg door samenwerking

automatisering

verplaatsing/nieuwbouw

Totaal interne veranderingen

Totaal organisaties

6
3
--
4
5
5
--
--
3
3
29
22

$\begin{array}{rr}39 \% & 13 \\ 39 \% & 13 \\ 12 \% & 4 \\ 15 \% & 5 \\ 12 \% & 4 \\ 12 \% & 4 \\ 6 \% & 2 \\ 9 \% & 3 \\ 18 \% & 6 \\ -- & -- \\ & 54 \\ & 33\end{array}$

$\begin{array}{rr}35 \% & 19 \\ 29 \% & 16 \\ 7 \% & 4 \\ 16 \% & 9 \\ 16 \% & 9 \\ 16 \% & 9 \\ 4 \% & 2 \\ 5 \% & 3 \\ 16 \% & 9 \\ 5 \% & 3 \\ & 83 \\ & 55\end{array}$

De genoemde externe veranderingen leiden er mede toe dat $27 \%$ van de zorginstellingen en $39 \%$ van de welzijnsorganisaties verwacht dat de organisatie in de komende twee jaar zal worden gereorganiseerd. Met name in de welzijnssector verwacht men mede daardoor veel nieuwe (contract)activiteiten te gaan ontwikkelen, terwijl in een enkel geval ook wordt aangegeven dat een aantal activiteiten zal worden afgestoten. Eén en ander betekent ook vaak

22. Het absolute aantal betreft het aantal organisaties dat een bepaalde verandering heeft genoemd, terwijl bij het relatieve aantal het absolute aantal is relateerd aan het totaal aantal onderzochte organisaties in de (deel)sector. 
dat de taakinhoud en de gehanteerde methoden zullen wijzigen terwijl een aantal welzijnsorganisaties verwachten meer (extern) overleg te moeten voeren door de (formele) samenwerking met andere organisaties. De reorganisaties zijn vaak gericht op een verdergaande interne decentralisatie, wat weer betekent dat er per team of afdeling zelfstandiger kan worden gewerkt. Naast een grotere gerichtheid op een meer integrale aanpak, wordt ook een verdergaande specialisatie verwacht en wordt registratie een belangrijk onderdeel van de zorgtaak. De zorginstellingen lijken wat meer naar binnen te zijn gericht dan de welzijnsorganisaties welke laatste met name bezig zijn de externe veranderingen intern hun beslag te laten krijgen. De zorginstellingen noemen relatief vaak veranderingen in het scholings- en personeelsbeleid, waarbij ziekteverzuim en de toenemende werkdruk eveneens een plaats in hebben. Ten slotte verwacht $16 \%$ van de werkgevers een verdergaande automatisering van de activiteiten in de organisatie.

Vervolgens is de werkgevers gevraagd hoe zij, mede gezien de door hen genoemde externe en interne veranderingen, de ontwikkeling van de totale werkgelegenheid bij de organisatie voor 1992 en 1993 inschatten. In tabel 5.2. is het percentage organisaties aangegeven dat respectievelijk een (sterke) toename, geen verandering, of (sterke) afname verwacht van de totale werkgelegenheid in de organisatie.

Tabel 5.2. Verwachte groei van de totale werkgelegenheid in de organisatie voor 1992 en 1993

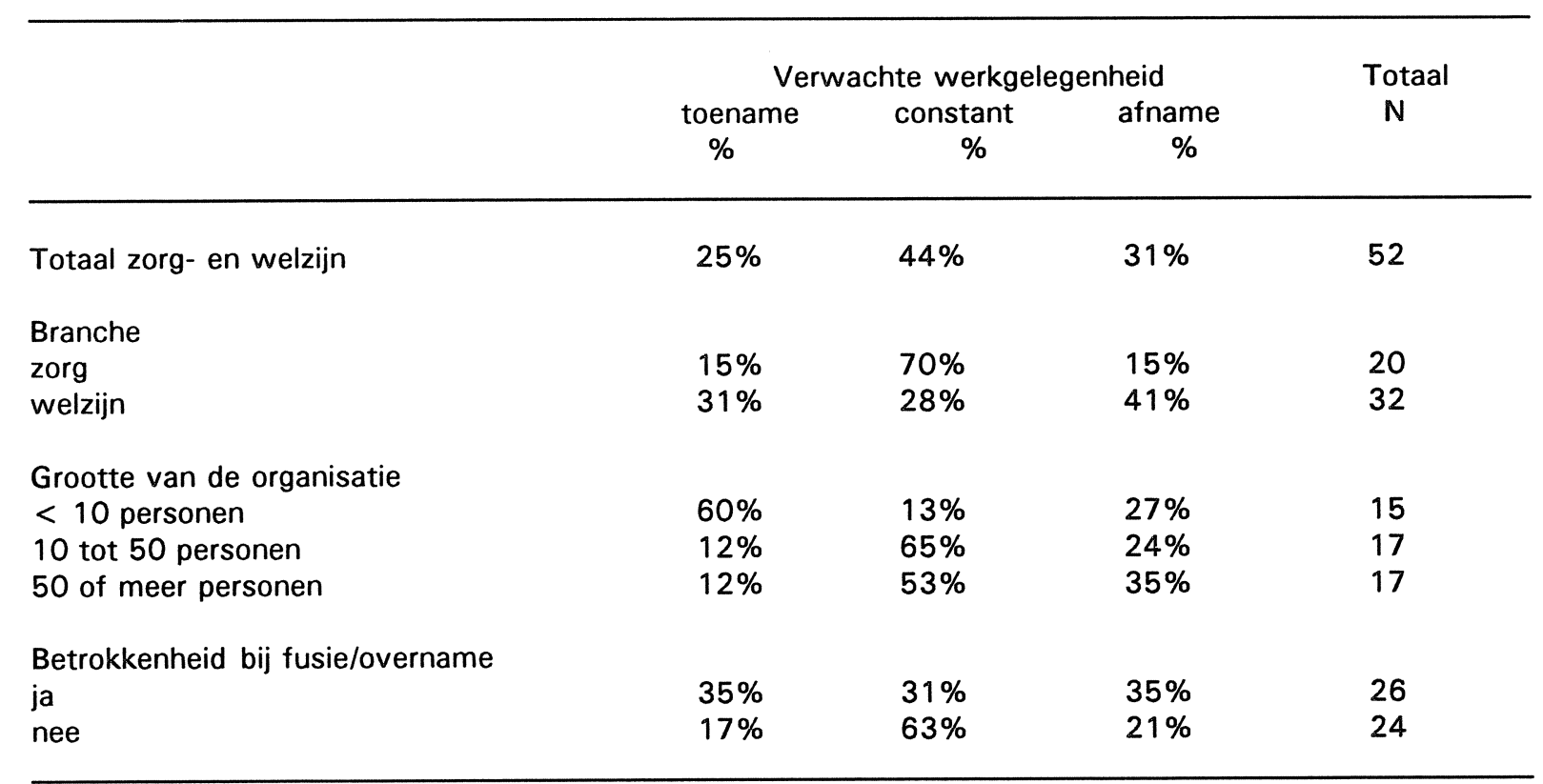

Een kwart van de organisaties verwacht een toename van de totale werkgelegenheid, bijna een derde deel verwacht een afname en $44 \%$ denkt dat de totale werkgelegenheid bij de organisatie de komende twee jaar constant zal blijven. De verschillen tussen de zorg- en welzijnssector zijn echter zeer groot $^{23}$. Terwijl van de zorginstellingen slechts $30 \%$ een wijziging in de totale

23. Hierbij dient wel te worden gerealiseerd dat in een kleine (welzijns)organisatie een toe-/afname in het personeelsbestand van slechts enkele werknemers relatief veel zwaarder weegt dan in een grote (zorg)instelling. 
werkgelegenheid verwacht, voorziet maar liefst $72 \%$ van de welzijnsorganisaties een toe- of afname in de werkgelegenheid. In de zorgsector verwacht een even groot percentage een toename als een afname. In de welzijnssector daarentegen verwacht een groter percentage een afname van de werkgelegenheid ( $41 \%$ versus $31 \%)$. Zoals al eerder is geconstateerd zijn de welzijnsorganisaties vaker betrokken bij fusies en overnames dan zorginstellingen. Organisaties die een dergelijke reorganisatie verwachten, verwachten dan ook vaker werkgelegenheidsveranderingen; overigens even vaak een toename als een afname hiervan. Welzijnsorganisaties zijn over het algemeen ook kleiner qua personeelsomvang dan zorginstellingen. Kleinere organisaties verwachten dan ook vaker een verandering in de werkgelegenheid. Tegen de verwachting in, verwachten deze kleine organisaties juist vaker een toename van de werkgelegenheid in plaats van een afname, hetgeen in de welzijnssector het geval is.

De werkgevers hebben daarnaast ook een inschatting gegeven van de verwachte werkgelegenheidsontwikkeling voor de in de organisatie vertegenwoordigde sociaal-agogische beroepenclusters in 1992 en 1993. Deze verwachtingen zijn in tabel 5.3. voor het totaal van het sociaalagogisch personeel aangegeven en voor de drie belangrijkste beroepenclusters.

Tabel 5.3. Verwachte groei van de werkgelegenheid per beroepencluster van het sociaal-agogisch personeel in de organisatie voor 1992 en 1993

\begin{tabular}{|c|c|c|c|c|}
\hline & $\begin{array}{r}\text { toename } \\
\%\end{array}$ & $\begin{array}{r}\text { Verwachte wer } \\
\text { constant } \\
\%\end{array}$ & $\begin{array}{r}\text { idsgroei } \\
\text { afname } \\
\%\end{array}$ & $\begin{array}{r}\text { Totaal } \\
\mathrm{N}\end{array}$ \\
\hline Totaal sociaal-agogisch personeel ${ }^{24}$ & $23 \%$ & $63 \%$ & $15 \%$ & 14 \\
\hline $\begin{array}{l}\text { Beroepencluster } \\
\text { maatschappelijk werkers } \\
\text { sociaal-pedagogische hulpverleners } \\
\text { leidinggevenden zorg en welzijn }\end{array}$ & $\begin{array}{l}35 \% \\
18 \% \\
13 \%\end{array}$ & $\begin{array}{l}47 \% \\
73 \% \\
63 \%\end{array}$ & $\begin{array}{r}18 \% \\
9 \% \\
25 \%\end{array}$ & $\begin{array}{l}34 \\
22 \\
32\end{array}$ \\
\hline
\end{tabular}

Het percentage organisaties dat een constante werkgelegenheid verwacht varieert van $47 \%$ voor de maatschappelijk werkers tot $73 \%$ voor de sociaal-pedagogische hulpverleners. Voor de maatschappelijk werkers wordt relatief vaak een groei in de werkgelegenheid verwacht, terwijl de leidinggevenden daarentegen naar verwachting met een afnemende werkgelegenheid te maken zullen krijgen. Uitgaande van het gewogen gemiddelde blijkt voor $23 \%$ van het totale sociaal-agogisch personeel een toename in de werkgelegenheid te worden verwacht, voor $15 \%$ een afname en voor $63 \%$ geen enkele verandering in de werkgelegenheid.

Om deze toe- dan wel afname nader te specificeren is de werkgevers tevens gevraagd per sociaal-agogisch beroepencluster een indicatie te geven van het aantal vacatures dat zij in 1992

24. Het gaat hier om een gewogen gemidddelde over het totale sociaal-agogisch personeel, waarbij weging heeft plaatsgevonden naar de omvang van de betreffende beroepenclusters. 
en 1993 tezamen verwachten. De werkgevers is verzocht hierbij een onderscheid te maken naar vacatures die ontstaan door uitbreiding van de werkgelegenheid (het aantal formatieplaatsen) en vacatures die zullen voortvloeien uit de vervanging van werknemers ten gevolge van pensionering, VUT, langdurige ziekte, zwanger- en ouderschapsverlof en vertrek naar een andere organisatie.

Het bleek voor veel werkgevers moeilijk om een schatting te geven van het aantal vacatures dat zij de komende twee jaar voor het sociaal-agogisch personeel verwachten. Het percentage werkgevers waar een bepaald beroepencluster is vertegenwoordigd en dat de vraag over de verwachte vacatures heeft beantwoord loopt uiteen van $39 \%$ voor het cluster van de leidinggevenden tot $63 \%$ voor de maatschappelijk werkers. Wanneer de respons op deze vraag wordt gerelateerd aan de formatie-omvang van de beroepenclusters dan blijkt over gemiddeld $74 \%$ van de sociaal-agogische formatieplaatsen de vacature-ontwikkeling te zijn aangegeven. In totaal hebben de werkgevers 183 vacatures gemeld. Wanneer dit wordt omgerekend naar de gehele formatie van sociaal-agogisch personeel betekent dit dat er in 1992 en 1993 in totaal bijna 250 vacatures door de werkgevers worden verwacht (183/0.74). Voor het totale sociaalagogisch personeel bedraagt het relatieve aandeel van de vacatures ten opzichte van het totaal aantal werkenden eind 1991 circa $17,5 \%$. Op jaarbasis bijna $9 \%$ hetgeen iets lager is dan het aantal vacatures dat in 1991 ruim $11 \%$ bedroeg van het totaal aan sociaal-agogisch personeel aan het begin van $1991(116+35 / 1380)$.

Werkgevers hebben de verwachte vacatures ten gevolge van vervanging van personeel overigens iets vaker ingevuld dan de vacatures ten gevolge van uitbreiding van het personeel. Hoewel vervanging van personeel als gevolg van langdurige ziekte, zwangerschap en vertrek naar een andere organisatie vooraf niet zo gemakkelijk is in te schatten, is de vervangingsvraag, bij een gelijkmatige leeftijdsopbouw van het betreffende personeel, in vergelijking met de uitbreidingsvraag over het algemeen vrij constant. De ontwikkeling van de uitbreidingsvraag daarentegen wordt sterk door externe factoren bepaald (bijvoorbeeld het subsidiebeleid van de overheid) en is derhalve moeilijk in te schatten.

Hoewel werkgevers voor het (uit)voeren van hun personeels- en scholingsbeleid vaak een grote behoefte hebben aan betrouwbare gegevens over de werkgelegenheidsontwikkelingen op middellange termijn, ontbreken deze gegevens meestal en moet men het meestal doen met subjectieve verwachtingen ten aanzien van toekomstige ontwikkelingen op de arbeidsmarkt. Uit het feit dat slechts de helft van de werkgevers lover ruim driekwart van de sociaal-agogische formatieplaatsen) de vraag over verwachte vacatures heeft ingevuld, blijkt wel hoe moeilijk het voor individuele werkgevers is om dergelijke schattingen te maken.

\subsection{Arbeidsmarktperspectief voor sociaal-agogisch personeel: een rekenvoorbeeld}

Met behulp van de door de werkgevers verschafte gegevens over de veranderingen in het personeelsbestand over het afgelopen jaar en gegevens over toekomstige arbeidsmarktontwikkelingen uit het ROA-informatiesysteem is het in principe mogelijk om een berekening te maken 
van de mogelijke toekomstige ontwikkelingen op de arbeidsmarkt voor de zorg- en welzijnssector. Daarbij kan zowel de uitbreiding en vervanging van sociaal-agogisch personeel aan de vraagzijde van dit arbeidsmarktsegment worden betrokken, als het aanbod van (hoger geschoold) sociaal-agogisch personeel. Vervolgens kunnen de ontwikkellingen aan de vraag- en aanbodzijde aan elkaar worden gerelateerd, zodat inzicht wordt verkregen in mogelijke arbeidsmarktperspectieven voor sociaal-agogisch personeel in de komende twee jaar.

Arbeidsmarktperspectief van hoger (voltijds) geschoold sociaal-agogisch personeel in Noord-Nederland in de periode 1992-1993

\section{Vraag}

vraag in onderzochte organisaties:

uitbreiding: $2 \%$ groei * 1400 beroepskrachten

$\approx 30$ personen

vervanging: $20 \%$ vervanging * 1400 beroepskrachten *1/4 nieuwkomers

$\approx 70$ personen

totaal vraag naar sociaal-agogisch personeel in onderzochte organisaties:

totaal vraag naar sociaal-agogisch personeel in Noord-Nederland:

aandeel afgestudeerden voltijds HSAO in vraag sociaal-agogisch personeel:

$+\cdots$

100 personen

* 6

600 personen

* 0,5

totale vraag afgestudeerden voltijds HSAO voor sociaal-agogische functie

in Noord-Nederland in 1992 en 1993:

300 personen

\section{Aanbod}

aanbod afgestudeerden voltijds HSAO in Noord-Nederland in 1992 en 1993:

aanbod maximaal 1 jaar werkloze voltijdse HSAO'ers in Noord-Nederland in 1992/'93:

totaal aanbod (al dan niet) werkloze voltijdse HSAO'ers in

Noord-Nederland in 1992 en 1993: circa kleine

$$
\begin{aligned}
& 360 \text { personen } \\
& 15 \text { personen } \\
+\cdots & \\
\approx 400 & \text { personen }
\end{aligned}
$$

Confrontatie vraag - aanbod

aanbodoverschot van

$\pm 100$

personen

\section{Arbeidsmarktperspectief}

werkloosheid en onderbenutting onder afgestudeerden van het voltijds HSAO

Bedacht moet worden dat het hier gaat om een rekenvoorbeeld. De gepresenteerde berekening dient vooral de mogelijkheden van dit type onderzoek aant te geven en kan dus niet worden beschouwd als een exacte voorspelling. Aangezien het hier om een pilot-onderzoek gaat en de benodigde gegevens niet altijd volledig beschikbaar waren, waardoor het rekenvoorbeeld een aantal - wellicht niet geheel juiste - vooronderstellingen bevat, kunnen aan de uitkomsten van dit rekenvoorbeeld ook geen conclusies worden verbonden. 


\section{Uitbreidingsvraag}

Allereerst wordt een indicatie gegeven van de verwachte werkgelegenheidsontwikkeling voor het sociaal-agogisch personeel in de onderzochte organisaties. Voor de toekomstige uitbreidingsvraag is uitgegaan van de landelijke prognose voor de beroepsklasse van maatschappelijk werkers e.d. uit het ROA-informatiesysteem. ${ }^{25}$ Naar verwachting zal de werkgelegenheid tussen 1989 en 1994 in deze beroepsklasse in Nederland met 6\% toenemen. In vergelijking met de andere ROA-beroepsklassen betekent dit een gemiddelde groei. Dit werkgeversonderzoek gaat echter niet uit van een 5-jarige prognoseperiode, maar van een 2-jarige. Ervan uitgaande dat de jaarlijkse groei tussen 1989 en 1994 gelijk blijft, wordt dus voor de periode 1992-1993 een groei van ruim $2 \%$ verwacht. Zoals reeds eerder is aangegeven waren er in 1991 ruim 1400 sociaal-agogische beroepsbeoefenaren bij de onderzochte zorg- en welzijnsorganisaties werkzaam. De uitbreidingsvraag bij deze organisaties bedraagt op basis van de ROA-prognose voor maatschappelijk werkers e.d. in de komende twee jaar dus circa 30 personen. Dat wil zeggen dat op jaarbasis de groei van de werkgelegenheid ten opzichte van de groei in 1991 wordt gehalveerd.

\section{Vervangingsvraag}

De vervangingsvraag, die ondermeer het gevolg is van pensionering, (tijdelijke) terugtrekking van de arbeidsmarkt en beroepsmobiliteit, wordt bepaald door de in de analyseperiode waargenomen geslachts- en leeftijdspecifieke verloopcoëfficiënten door te trekken naar de toekomst. Daarbij wordt gecorrigeerd voor de conjuncturele component in het verloop in de analyseperiode (de uitstroom van werkenden naar het werklozenbestand). Bovendien vindt een correctie plaats voor de verwachte ontwikkeling van de participatiegraad per geslacht en leeftijdscategorie (zie Willems en De Grip, 1990).

Doorberekening van deze vervangingsvraag op het gebruikte zorg-en welzijnsbestand voor de periode 1992-1993 levert een totaal aantal van 290 personen op. Wanneer dit wordt gerelateerd aan het totaal aantal personen dat in 1991 in de onderzochte organisaties in een sociaalagogische functie werkzaam was, bedraagt de procentuele vervangingsvraag ruim $20 \%$, oftewel $10 \%$ op jaarbasis.

Hierbij is ook de vervanging meegerekend van personeel dat bij een andere organisatie is gaan werken. Van deze 'baanopeningen' zijn er ongeveer 70 bestemd voor nieuwkomers op de arbeidsmarkt. Immers een kwart van de vacatures uit 1991 bij de zorg- en welzijnsorganisaties is vervuld door kandidaten met minder dan 1 jaar werkervaring.

25. De meest recente ROA-prognoses behelzen de periode 1989-1994 en zijn opgenomen in het rapport 'De arbeidsmarkt naar opleiding en beroep tot 1994'. De prognoses hebben betrekking op 93 beroepsklassen en 49 opleidingstypen verdeeld over de volle breedte van de arbeidsmarkt. 


\section{Arbeidsmarktperspectief}

Het totaal aantal baanopeningen voor nieuwkomers in sociaal-agogische functies in de onderzochte organisaties wordt derhalve voor 1992 en 1993 tezamen op circa 100 personen geschat. Op grond van gegevens uit het ROA-informatiesysteem is berekend dat ongeveer én op de zes sociaal-agogische beroepsbeoefenaren uit Noord-Nederland in één van de onderzochte organisaties werkzaam was. Dit betekent dat het aantal baanopeningen voor sociaal-agogisch personeel voor 1992 en 1993 in de drie Noordelijke provincies op basis van onze berekeningen ongeveer 600 zal bedragen.

Om deze baanopeningen concurreren HSAO'ers en andere HBO'ers met afgestudeerden van het WO en MBO. Naar schatting de helft van deze baanopeningen zal vrij komen voor afgestudeerden van het voltijds HSAO. Met andere woorden: er zullen ongeveer 300 plaatsen vrijkomen voor afgestudeerden van het voltijdse HSAO.

De vraag naar hoger (voltijds) geschoold sociaal-agogisch personeel wordt vervolgens gerelateerd aan het aanbod van dit personeel, om een indicatie te verkrijgen van de krapte, dan wel de ruimte in 1992 en 1993 in dit arbeidsmarktsegment in Noord-Nederland.

Uiteraard zullen niet alle HSAO'ers die in Noord-Nederland hun (voltijdse) opleiding hebben voltooid, zich in Noord-Nederland aanbieden. Omgekeerd zal een deel van de afgestudeerde HSAO'ers uit de rest van Nederland zich in één van de drie noordelijke provincies (willen) vestigen. Het lijkt echter waarschijnlijk dat de preferenties van de HSAO'ers uit Noord-Nederland wat betreft een (potentiële) werkgemeente niet sterk zullen afwijken van HSAO'ers uit andere regio's. Voor zover HSAO'ers uit Noord-Nederland vaker buiten deze regio een baan accepteren lijkt dit vooral bepaald door de regionale verschillen in de vraag naar HSAO'ers. De uitstroom van HSAO'ers die in één van de drie noordelijke provincies aan een voltijdse studierichting zijn afgestudeerd is dus het uitgangspunt voor de raming van het aanbod van sociaal-agogisch personeel in Noord-Nederland.

In hoofdstuk 4 is reeds geconstateerd, dat slechts $2 \%$ van het sociaal-agogisch personeel in de onderzochte organisaties als personeelswerker werkzaam is. Juist omdat de afgestudeerden van de studierichting Personeel \& Arbeid in principe voor een geheel ander arbeidsmarktsegment worden opgeleid dan de andere sociaal-agogen die min of meer op hetzelfde arbeidsmarktsegment opereren, zijn de afgestudeerden van de studierichting Personeel \& Arbeid niet in de raming van het aanbod opgenomen.

Op basis van onderwijsprognoses van het ministerie van Onderwijs \& Wetenschappen en onderwijsstatistieken van het Centraal Bureau voor de Statistiek (CBS) wordt het jaarlijkse aantal afgestudeerden van het voltijdse HSAO (exclusief Personeel \& Arbeid) in de drie noordelijke provincies op circa 200 personen geschat. Bijna $90 \%$ zal hiervan willen doorstromen naar de arbeidsmarkt: $14 \%$ studeert namelijk verder, maar $15 \%$ hiervan is wel op zoek naar werk (Zie Van de Loo, Ramaekers en Van der Velden, 1992). In de periode 1992-1993 
verwachten wij dus dat 360 afgestudeerden van voltijdse HSAO-opleidingen zich in én van de drie noordelijke provincies zullen aanbieden op de arbeidsmarkt voor (hoger) sociaal-agogisch personeel.

In principe worden afgestudeerden van de voltijdse HSAO-opleidingen die minder dan een jaar werkloos zijn ook gerekend tot het aanbod. Deze werklozen concurreren immers met de pas afgestudeerden om de beschikbare banen. Van de in het studiejaar 1989/' 90 afgestudeerde HSAO'ers van de voltijdse opleidingen bleek ruim een jaar na afstuderen $8,6 \%$ werkloos te zijn (zie Van de Loo, Ramaekers en Van der Velden, 1992). Dit betekent dat in de periode 19921993 nog eens 15 (180 x 0.086) werkloze HSAO'ers naar verwachting zullen concurreren met pas afgestudeerde HSAO'ers om de dan vrijgekomen sociaal-agogische functies.

Bij het aanbod gaat het uiteraard alleen om personen die zich (willen) aanbieden voor sociaalagogische functies. Zoals uit gegevens van de HBO-Monitor blijkt, is $89 \%$ van de werkende HSAO'ers (exclusief Personeel \& Arbeid) in een sociaal-agogische functie werkzaam. Deze functies worden zo goed als allemaal in de zorg- en welzijnssector uitgevoerd. Het feit dat niet $100 \%$ van de afgestudeerden in sociaal-agogische functies werkzaam is, lijkt eerder te komen doordat het niet alle HSAO'ers lukt om een sociaal-agogische functie te bemachtigen, dan dat ruim $10 \%$ - reeds een jaar na afstuderen - geen sociaal-agogische functie (meer) ambieert. Hiervoor is dus geen correctie toegepast.

Uitgaande van het berekende aantal baanopeningen betekent dit dat het aanbod de vraag enigzins zal overtreffen, hetgeen kan betekenen, dat niet alle afgestudeerde HSAO'ers werk in hun arbeidsmarktsegment zullen kunnen vinden.

Hierbij moet niet uit het oog worden verloren, dat de afgestudeerden van het (voltijds) HSAO op een vrij open arbeidsmarktsegment opereren. Enerzijds zullen de HSAO'ers juist de lager geschoolden MDGO'ers verdringen, waarbij HSAO'ers de kans lopen dat hun kwalificaties worden onderbenut. Anderzijds kunnen de HSAO'ers op hun beurt weer veel concurrentie ondervinden van universitair geschoolden. Daarnaast concurreren afgestudeerde HSAO'ers met het bestaande sociaal-agogisch personeel om de vrij te komen arbeidsplaatsen. Ouder sociaalagogisch personeel heeft, met name in het verleden, nogal eens 'het veld moeten ruimen' voor pas afgestudeerde HSAO'ers. Een verschijnsel dat zich overigens niet tot de zorg- en welzijnssector heeft beperkt. Ten slotte kunnen afgestudeerde HSAO'ers er ook voor kiezen om eerst nog enkele jaren verder te studeren, om daarmee een betere uitgangspositie voor een (goede) baan in de zorg- en welzijnssector te verwerven. Voor een goed inzicht in de uiteindelijke resultaten van dit selectieproces wordt verwezen naar de HBO-Monitor, het onderzoek onder de afgestudeerden, dat juist antwoord geeft op dit soort vragen. 


\section{SCHOLINGSBELEID VOOR SOCIAAL-AGOGISCH PERSONEEL}

\subsection{Inleiding}

Zoals in hoofdstuk 1 reeds is aangegeven zal er door zowel maatschappelijke ontwikkelingen als een aantal ingrijpende organisatorische veranderingen in de zorg- en welzijnssector sprake zijn van een sterke dynamiek in de beroepsuitoefening en het werkveld. Juist de kwalitatieve aansluiting tussen opleiding en beroepenveld kan door deze ontwikkelingen dan onder druk komen te staan (Van der Top, 1989). In dit hoofdstuk wordt daarom het scholingsbeleid van de zorg- en welzijnsorganisaties onder de loupe genomen.

Demografische, technologische en organisatorische factoren zullen de scholingsbehoefte door organisaties positief beïnvloeden (Allaart, Praat en Vosse, 1992). Bij de demografische factoren gaat het enerzijds om het relatief ouder worden van de beroepsbevolking en anderzijds om een relatieve afname van de toestroom van jongeren naar de arbeidsmarkt. Het eerste leidt tot een toenemende noodzaak tot inspanningen om bestaande kwalificaties van werknemers up to date te houden; het tweede aspect leidt tot extra scholingsbehoefte indien onder de beperktere keuze uit schoolverlaters de vereiste kwalificaties onvoldoende aanwezig zijn. In de zorg- en welzijnssector komt daar nog bij dat ook het patiënten-, c.q. cliëntenbestand veroudert, hetgeen specifieke eisen stelt aan de kwalificaties van het personeel. Automatisering van allerlei werkzaamheden zal eveneens tot aanvullende scholingsactiviteiten leiden en (steeds weer) veranderende inzichten over de optimale organisatiestructuur, managementstijlen en de (hierbij) vereiste flexibiliteit van de werknemers kunnen eveneens een toename van scholingsactiviteiten tot gevolg hebben. Zo vindt er in de zorg- en welzijnssector de afgelopen, maar ook komende, jaren enerzijds schaalvergroting plaats van de organisaties, terwijl er anderzijds sprake is van decentralisering van de financiering van de activiteiten van deze (vergrote) organisaties.

In paragraaf 6.2. wordt aandacht geschonken aan de omvang van de scholingsactiviteiten in de zorg- en welzijnssector. Er wordt nagegaan hoeveel organisaties het sociaal-agogisch personeel aan interne dan wel externe scholingsactiviteiten laten deelnemen, hoeveel procent van het sociaal-agogisch personeel hierin participeert, hoeveel werktijd en kosten met deze scholingsactiviteiten zijn gemoeid en welk percentage van de kosten is besteed aan externe opleidingen. Hierbij wordt een onderscheid gemaakt naar de zorg- en welzijnssector, grootte, status en jaarlijkse groei van de organisaties, alsmede de verwachtingen omtrent de werkgelegenheidsgroei in de nabije toekomst. Daarnaast zal worden nagegaan of organisaties die in 1991 of in 1992/'93 betrokken waren (of zullen zijn) bij een reorganisatie vaker hun sociaal-agogisch personeel scholingsactiviteiten laten volgen dan organisaties waarbij geen sprake is van een (recente of verwachte) reorganisatie. Ook zal worden geïnventariseerd of er verschillen bestaan in deelname tussen beide sexen. Paragraaf 6.3. gaat in op de motieven die de werkgevers aandragen om hun sociaal-agogisch personeel aanvullende scholing aan te bieden. 


\subsection{Omvang scholing van sociaal-agogisch personeel}

In dit pilot-onderzoek hebben 48 zorg- en welzijnsorganisaties opgegeven dat minimaal één sociaal-agogisch personeelslid in 1991 heeft deelgenomen aan interne dan wel externe scholingsactiviteiten. Interne scholingsactiviteiten zijn door de organisatie zelf georganiseerde cursussen, terwijl externe cursussen buitenshuis door anderen worden georganiseerd.

Wanneer ervan uit wordt gegaan dat bij de organisaties die niets over het scholingsbeleid hebben gemeld (de ontbrekende waarden) inderdaad niemand van het sociaal-agogisch personeel scholingsactiviteiten in 1991 heeft gevolgd, betekent dit derhalve dat $87 \%$ van de onderzochte zorg- en welzijnsinstellingen sociaal-agogisch personeel een cursus heeft laten volgen $^{26}$. Voor de zorgsector is het percentage vrijwel gelijk aan dat voor de welzijnssector $(86 \%$ versus $88 \%)$.

Het percentage voor de totale zorg- en welzijnssector komt aardig overeen met hetgeen in 1990 reeds in het arbeidsvraagpanel van de OSA (Organisatie voor Strategisch Arbeidsmarktonderzoek) werd geconstateerd. In het Trendrapport over de vraag naar arbeid geven Allaart e.a. (1992) aan dat in 1990 bijna $83 \%$ van de door hen onderzochte organisaties in de particuliere en collectieve sector éen of meerdere werknemers in dienst had die in dat jaar deelnamen aan een interne of externe cursus. Bij deze vergelijking dient men zich overigens te realiseren dat, ondanks een gelijke vraagstelling, de resultaten uit het werkgeversonderzoek niet zonder meer met die van de OSA en het CBS vergelijkbaar zijn. Het scholingsbeleid heeft in dit pilot-onderzoek immers niet betrekking op de totale organisatie, maar alleen op het sociaalagogisch personeel. Bovendien hebben de gegevens van de OSA ${ }^{27}$ betrekking op 1990, terwijl dit pilot-onderzoek 1991 betreft.

De organisaties waarbij sociaal-agogisch personeel in 1991 een cursus heeft gevolgd hebben in dat jaar gemiddeld bijna 10 deelnemers gemeld. Bij de zorginstellingen namen gemiddeld bijna 14 sociaal-agogische personeelsleden aan scholingsactiviteiten deel, terwijl het bij de welzijnsorganisaties gemiddeld om zo'n 7 deelnemers ging. Dit verschil hangt mede samen met het verschil naar organisatiegrootte (zie ook hoofdstuk 3). Zo hebben vestigingen met minder dan 50 werknemers gemiddeld 8 deelnemers opgegeven, terwijl vestigingen met minimaal 200 werknemers gemiddeld bijna 14 sociaal-agogische personeelsleden meldden die in 1991 aan scholingsactiviteiten hebben deelgenomen, terwijl het bij organisaties met minimaal 50 en maximaal 199 werknemers om gemiddeld zo'n 11 deelnemers ging.

26. Indien men dit percentage baseert op alleen degenen die expliciet hebben vermeld dat er in 19910 deelnemers waren en de ontbrekende waarden dus buiten beschouwing worden gelaten, dan bedraagt het percentage organisaties waar in 1991 minimaal 1 sociaal-agogisch personeelslid scholingsactiviteiten heeft gevolgd $96 \%$.

27. In principe komen de vragen in dit pilot onderzoek overeen met de vragen die het CBS aan werkgevers over scholingsactiviteiten heeft voorgelegd. Anders dan de OSA heeft het CBS bij dit onderzoek naar bedrijfsopleidingen alleen de particuliere sector betrokken. 
Om na te gaan of er verschillen bestaan tussen verschillende soorten organisaties is het dus beter om te kijken naar verschillen in deelnemingspercentage. ${ }^{28}$ Het deelnemingspercentage is hier gedefinieerd als het procentueel aandeel van het sociaal-agogisch personeel dat in 1991 scholingsactiviteiten heeft gevolgd. Het gaat hier om de organisaties waarbij minimaal één sociaal-agogisch personeelslid in 1991 scholing heeft gevolgd. Indien een werknemer aan meerdere scholingsactiviteiten in dat jaar deelnam is deze slechts éénmaal als deelnemer meegeteld.

Tabel 6.1. Gemiddelde deelname van sociaal-agogisch personeel aan scholingsactiviteiten in 1991 in procenten van het sociaal-agogisch personeel naar kenmerken organisatie.

\begin{tabular}{|c|c|c|}
\hline & Deelnemingspercentage & N \\
\hline Totaal zorg- en welzijnssector & $45 \%$ & 45 \\
\hline \multicolumn{3}{|l|}{ Branche } \\
\hline $\begin{array}{l}\text { zorgsector } \\
\text { welzijnssector }\end{array}$ & $\begin{array}{l}31 \% \\
56 \%\end{array}$ & $\begin{array}{l}19 \\
26\end{array}$ \\
\hline \multicolumn{3}{|l|}{ Grootteklasse vestiging } \\
\hline $1-9$ personen & $56 \%$ & 11 \\
\hline 10- 49 personen & $46 \%$ & 15 \\
\hline 50 personen of meer & $31 \%$ & 16 \\
\hline \multicolumn{3}{|l|}{ Status organisatie } \\
\hline $\begin{array}{l}\text { nevenvestiging } \\
\text { hoofd- of zelfstandige vestiging }\end{array}$ & $37 \%$ & $\begin{array}{l}15 \\
29\end{array}$ \\
\hline hoofd- of zelfstandige vestiging & & \\
\hline \multicolumn{3}{|l|}{ Jaarlijkse Groei budget } \\
\hline $\begin{array}{l}<1 \% \\
\geq 1 \%\end{array}$ & $51 \%$ & 16 \\
\hline \multicolumn{3}{|l|}{ Verwachtingen werkgelegenheid '92/'93 } \\
\hline (sterke) toename & $39 \%$ & 12 \\
\hline constant & $46 \%$ & 19 \\
\hline (sterke) afname & $55 \%$ & 12 \\
\hline \multicolumn{3}{|l|}{ Reorganisatie '91 } \\
\hline nee & $44 \%$ & 37 \\
\hline ja & $53 \%$ & 7 \\
\hline \multicolumn{3}{|l|}{ Reorganisatie '92/'93 } \\
\hline $\begin{array}{l}\text { nee } \\
\text { ja }\end{array}$ & $\begin{array}{l}45 \% \\
44 \%\end{array}$ & $\begin{array}{l}20 \\
22\end{array}$ \\
\hline ja & & \\
\hline
\end{tabular}

28. Het CBS en de OSA constateren dat het bij grote organisaties vaker voorkomt dat er minimaal één werknemer aan scholingsactiviteiten deelneemt, dan bij kleine organisaties. Zij wijten dit verschil aan het feit dat er bij grote organisaties veelal ook een aparte functionaris of afdeling voor het scholingsbeleid aanwezig is. Volgens ons heeft dit in de eerste plaats echter een statistische oorzaak. De kans dat een klein bedrijf geen enkele werknemer in een bepaald jaar een cursus laat volgen is groter omdat er hier minder mensen werken. 
Gemiddeld blijkt $45 \%$ van het sociaal-agogisch personeel in 1991 aan een interne of externe opleiding of cursus te hebben deelgenomen. Dit lijkt in vergelijking met het deelnemingspercentage van $24 \%$ dat de OSA zowel voor de zorgsector als voor het totaal van de particuliere en collectieve sector heeft berekend in eerste instantie veel. Doch, de OSA constateert enerzijds dat het deelnemingspercentage, met name in de marktsector, afneemt met een toename van het percentage laagopgeleiden en anderzijds dat vooral in bedrijven waar meer dan $30 \%$ van de werknemers uit $\mathrm{HBO}$ - en WO-afgestudeerden bestaan, de cursusdeelname relatief hoog is (Allaart e.a., 1992).

Uit de landelijke sectorrapportage van de HBO-Monitor over het HSAO blijkt, dat $31 \%$ van de werkende $\mathrm{HSAO}^{\prime}$ ers (en $40 \%$ van alle HBO'ers tezamen) na het afstuderen in het studiejaar 1989/'90 bijscholing heeft gevolgd (Van de Loo, e.a., 1992). De werkende afgestudeerden van de voltijdse studierichting sociaal-pedagogische hulpverlening (voorheen inrichtingswerk en jeugdwelzijnswerk) hebben relatief het minst vaak aan bijscholing deelgenomen (namelijk $22 \%$ ), terwijl de werkende afgestudeerden van de deeltijdse studierichting maatschappelijk werk relatief het vaakst een bijscholingscursus hebben gevolgd: $41 \%$. Het verschil in cursusdeelname tussen de werkende in 1989/' 90 afgestudeerde HSAO'ers en het sociaal-agogisch personeel in de onderzochte zorg- en welzijnsinstellingen kan verschillende oorzaken hebben. Enerzijds is het mogelijk, dat de onderzochte organisaties toevallig meer aan scholing doen dan gebruikelijk is bij werkgevers van HSAO'ers. Bovendien zijn de populaties verschillend: niet all sociaal-agogische personeelsleden hebben een HSAO-opleiding gevolgd en niet elke afgestudeerde HSAO-er is werkzaam in een sociaal-agogische functie. Ook is het mogelijk dat afgestudeerden - door de vraagstelling - minder geneigd zijn om het volgen van (interne) cursussen te melden. Ten slotte kan dit verschil er ook op duiden dat werkgevers bijscholing belangrijker vinden voor personeel dat al langer in dienst is dan voor pas afgestudeerden. In paragraaf 6.3. wordt hierop nader ingegaan.

Zoals men in tabel 6.1. kan aflezen is het deelnemingspercentage in de zorgsector gemiddeld lager dan in de welzijnssector. Dit sluit aan bij de relatief lage cursusdeelname onder de werkende afgestudeerden van de voltijdse studierichting sociaal-pedagogische hulpverlening. Deze afgestudeerden werken immers voornamelijk in de zorgsector. Bovendien blijkt het lagere deelnemingspercentage in de zorgsector samen te hangen met het feit dat de zorginstellingen over het algemeen groter zijn dan de welzijnsorganisaties.

Anders dan in het Trendrapport over de vraag naar arbeid van de OSA waar in 1990 geen eenduidige relatie tussen personeelsomvang van de organisatie en totale gemiddelde deelnemingspercentage werd gevonden, kan uit tabel 6.1. worden geconcludeerd dat met het toenemen van de personeelsomvang van de organisatie de cursusdeelname afneemt. Van $56 \%$ voor organisaties met minder dan 10 werknemers tot $31 \%$ voor organisaties waar minimaal 50 mensen werkzaam zijn. Overigens vindt de OSA deze relatie wel wanneer afzonderlijk wordt gekeken naar de deelname aan interne opleidingen en externe cursussen. De afname van het deelnemingspercentage bij een toenemende personeelsomvang van de organisatie wijten Allaart e.a. aan een efficiënter scholingsbeleid bij grotere organisaties. Door de aanwezigheid van een 
eigen scholingsafdeling of functionaris zou een adequatere keuze kunnen worden gemaakt binnen het scholingsaanbod, waarmee de scholingsbehoefte gerichter wordt vervuld en het risico dat cursussen achteraf niet aan de verwachtingen blijken te voldoen wordt verminderd.

Niet uitgesloten mag overigens worden, dat bij grote organisaties de respondent zijn/haar collega's minder goed kent of dat deze voor de respondent minder goed aanspreekbaar zijn, zodat het aantal opgegeven deelnemers bij grote organisaties wellicht een onderschatting is van het feitelijk aantal deelnemers. Respondenten uit zorginstellingen hebben ook relatief vaker aangegeven dat hun antwoorden met betrekking tot het scholingsbeleid zijn gebaseerd op (nauwkeurige) schattingen in plaats van gegevens uit het jaarverslag of personeelsinformatiesysteem e.d. dan respondenten die in welzijnsorganisaties werkzaam zijn ( $53 \%$ versus $28 \%$ ).

Verder blijkt het deelnemingspercentage voor zelfstandige organisaties en hoofdvestigingen hoger te zijn dan voor organisaties waar het om een nevenvestiging gaat.

Ten slotte is ook gekeken of er een samenhang bestaat tussen de huidige of toekomstige situatie van de organisatie en de cursusdeelname onder het sociaal-agogisch personeel. Hier zijn zowel de jaarlijkse groei van het budget, de verwachtingen omtrent de werkgelegenheid in de nabije toekomst alsmede recent voorgekomen of verwachte reorganisaties bij betrokken. Wanneer de resultaten hiervan in tabel 6.1. in ogenschouw worden genomen ontstaat voorzichtig - het volgende beeld. Organisaties waarvan het budget tussen 1990 en 1992 jaarlijks met minder dan $1 \%$ gegroeid, evenals organisaties die de laatste jaren met een reorganisatie te maken hebben gehad en/of voor 1992 of 1993 een afname van de werkgelegenheid in hun organisatie verwachten kennen een iets hogere cursusdeelname dan organisaties waarvan het budget de afgelopen twee jaren sterker is gegroeid en/of een toename verwachten van de werkgelegenheid en/of geen reorganisatie achter de rug hebben gehad. Er lijkt geen verschil in cursusdeelname te bestaan tussen organisaties die voor de komende twee jaar wel en juist geen reorganisatie verwachten. Bovenstaande overziend lijken cursussen met name te worden gevolgd bij organisaties waar problemen zijn geweest of binnenkort worden verwacht. Gegeven het aantal waarnemingen in de onderscheiden klassen kan hier slechts worden gesproken over mogelijke tendensen.

Zoals gezegd, zou er ook worden nagegaan of er bij de onderzochte zorg-en welzijnsinstellingen een verschil is tussen mannen en vrouwen in cursusdeelname. Dit blijkt niet het geval te zijn. Beide sexen hebben namelijk een deelnemingspercentage van $45 \%$.

In tabel 6.2. zijn voor de zorg- en welzijnsinstellingen die in 1991 sociaal-agogisch personeel scholingsactiviteiten hebben laten volgen de gemiddelde totale scholingskosten per deelnemer en organisatie aangegeven, evenals het percentage van de scholingskosten dat de organisaties aan externe opleidingen hebben besteed. In deze tabel is ook de totale gederfde werktijd per deelnemer en organisatie wegens het deelnemen aan scholingsactiviteiten weergegeven. Per deelnemer wordt gemiddeld ruim $f 2.000,--$ aan scholingsactiviteiten besteed. Hierbij bestaat er geen verschil tussen de welzijnsorganisaties en zorginstellingen. Dat de zorginstellingen 
gemiddeld dus bijna twee maal zoveel scholingskosten hebben vloeit voort uit het feit dat zij, zoals we reeds eerder hebben geconstateerd, gemiddeld ook twee maal zoveel deelnemers hebben.

De werkgevers was gevraagd om de totale scholingskosten te noteren. Hierbij gaat het zowel om kosten van interne en externe opleidingen, als de gederfde bruto loonsom, vergoedingen voor studie-, reis- en verblijfkosten van deelnemers, uitgaven aan scholingsfunctionarissen, cursusontwikkeling e.d. Gezien de gemiddelde hoogte van de kosten per deelnemer en van het percentage dat aan externe opleidingen is besteed, bestaat echter het vermoeden dat een aantal organisaties zich bij de opgave heeft beperkt tot de prijs die is betaald voor (externe) opleidingen.

Tabel 6.2. Gemiddelde totale scholingskosten, het gemiddelde percentage externe scholingskosten daarvan en gederfde werktijd van sociaal-agogisch personeel in zorg- en welzijnsinstellingen in 1991 , in guldens, procenten en dagen

\begin{tabular}{lcccc}
\hline & Zorg & Welzijn & Totaal Zorg- en Welzijn \\
& & & & \\
\hline $\begin{array}{l}\text { Kosten in guldens } \\
\text { per deelnemer } \\
\text { per organisatie }\end{array}$ & 2.100 & 2.100 & 2.100 & 41 \\
$\%$ aandeel extern & 6.100 & 15.100 & 20.600 & 41 \\
$\begin{array}{l}\text { Gederfde werktijd } \\
\text { in dagen }\end{array}$ & $84 \%$ & $80 \%$ & $73 \%$ & 37 \\
$\begin{array}{l}\text { per deelnemer } \\
\text { per organisatie }\end{array}$ & 118 & & & \\
\hline
\end{tabular}

Welzijnsorganisaties hebben verhoudingsgewijs meer geld besteed aan externe scholingsactiviteiten dan de zorginstellingen ( $80 \%$ versus $64 \%)$. Dit lijkt wederom in de eerste plaats samen te hangen met de grootte van de organisaties. Terwijl organisaties waarin minder dan 50 mensen werkzaam zijn gemiddeld $77 \%$ van hun totale scholingskosten extern besteden, geven organisaties met minimaal 200 werknemers gemiddeld slechts $58 \%$ van hun totale scholingskosten aan externe opleidingen uit.

Er zijn nagenoeg geen verschillen tussen de zorg- en welzijnssector wat betreft de gemiddelde gederfde werktijd per deelnemer. Het sociaal-agogisch personeel was gemiddeld - in de werktijd - zo'n acht dagen bezig met de in 1991 gevolgde opleiding. Als gevolg van het twee maal zo groot aantal deelnemers kostte de scholingsactiviteiten een zorginstelling gemiddeld 118 werkdagen en een welzijnsorganisatie derhalve gemiddeld circa de helft: namelijk 57 werkdagen. 


\subsection{Motieven voor scholing van sociaal-agogisch personeel}

In de inleiding zijn in het kort al enkele globale redenen aangegeven waarom organisaties voor hun werknemers scholingsactiviteiten zouden kunnen opzetten. In deze laatste paragraaf zal hierop nader worden ingegaan.

De werkgevers hebben de twee voornaamste doelen, c.q. motieven aangegeven van de cursussen die het sociaal-agogisch personeel in 1991 heeft gevolgd. In tabel 6.3. zijn hun antwoorden daarop weergegeven.

Het motief 'inwerken' voor het aanbieden van scholingsactiviteiten aan sociaal-agogisch personeel wordt het vaakst genoemd, namelijk door ruim driekwart van de ondervraagde werkgevers. Hiermee wordt zowel een introductie in de organisatie bedoeld als een aanvullende scholing op de genoten opleiding van nieuwe werknemers tot het niveau dat is vereist voor een goede uitoefening van de huidige functie. Hieruit kan men in ieder geval concluderen dat het geconstateerde verschil in cursusdeelname tussen de pas afgestudeerde HSAO'ers en het sociaal-agogisch personeel in de onderzochte zorg- en welzijnsorganisaties niet toegeschreven kan worden aan het idee dat een aanvullende cursus voor pas afgestudeerden minder nodig wordt geacht dan een cursus voor personeel dat al langer in dienst is (zie ook paragraaf 6.1.).

Tabel 6.3. Percentage organisaties met bepaald motief voor scholing van sociaal-agogisch personeel in 1991 (twee antwoorden mogelijk)

\begin{tabular}{lcccc}
\hline & $\begin{array}{c}\text { Zorg } \\
\%\end{array}$ & $\begin{array}{c}\text { Welzijn } \\
\%\end{array}$ & $\begin{array}{c}\text { Totaal Zorg- en Welzijn } \\
\% \\
N^{29}\end{array}$ & \\
\hline & & & & 37 \\
$\begin{array}{l}\text { Motief } \\
\text { inwerken } \\
\text { bijblijven } \\
\text { promotie }\end{array}$ & $63 \%$ & $86 \%$ & $56 \%$ & 27 \\
& $58 \%$ & $55 \%$ & $13 \%$ & 6 \\
\hline
\end{tabular}

Werkgevers uit de welzijnssector geven naar verhouding vaker aan dat 'inwerken' een belangrijk doel is dan werkgevers uit de zorgsector $(86 \%$ versus $63 \%)$. Al eerder werd geconstateerd dat het deelnemingspercentage in de zorgsector ook lager was dan in de welzijnssector. Bovendien bleken afgestudeerden die met name in de zorgsector werkzaam zijn minder vaak bijscholing te volgen dan afgestudeerden die vaak ook in de welzijnssector terecht komen. Dit kan er op duiden dat afgestudeerden van studierichtingen die voornamelijk opleiden voor de zorgsector, zoals sociaal-pedagogische hulpverlening, vaker direct inzetbaar zijn dan de afgestudeerden van andere HSAO-opleidingen. Juist een instrument als het Werkveld Informatiesysteem (WIS), dat

29. In totaal hebben 48 organisaties $(=87 \%)$ de vraag naar doel van de scholing beantwoord. Doordat de werkgevers twee doelen mochten aangeven is de som van de aantallen bij de onderscheiden antwoordcategorieën hoger dan 48. 
eveneens behoort tot het monitoringsysteem HSAO - werkveld, kan op deze vraag een antwoord geven.

Het 'bijblijven' behelst scholing als gevolg van of ter voorbereiding op een verandering van de functie of de functie-inhoud op hetzelfde functieniveau. Ruim de helft (56\%) van de organisaties laat weten dat dit (ook) een belangrijk doel is van de cursussen die het sociaal-agogisch personeel in 1991 heeft gevolgd. Het percentage is voor de welzijnssector vrijwel gelijk aan dat voor de zorgsector.

Scholing in het kader van een 'promotie' vindt plaats als gevolg van of ter voorbereiding op een verandering van de functie of functie-inhoud op een hoger functieniveau. Hierbij zij wel opgemerkt dat het niet altijd even eenvoudig zal zijn om te bepalen of met de verandering van de functie-inhoud ook een ander, c.q. hoger functieniveau is gemoeid. Als criterium kan het beste worden aangehouden of men in de organisatie ook echt 'promotie' maakt; toewijzing van een hogere schaal ten gevolge van functiewijziging (of de inhoud daarvan) en/of een betere beloning naar aanleiding daarvan. In vergelijking met de andere twee motieven wordt dit motief slechts een enkele keer genoemd.

Werkgevers konden ook een ander motief, c.q. doel aangeven. Voor zover het hier in feite niet om één van bovenstaande doelen ging, betrof het bijna altijd scholing in het kader van een (verwachte) reorganisatie in de zorg- en welzijnssector in het algemeen of de organisatie in het bijzonder.

In vergelijking met de resultaten van het OSA-arbeidsvraagpanel (Allaart e.a., 1992) blijkt bij de onderzochte zorg- en welzijnsorganisaties 'inwerken' relatief vaker te worden genoemd en 'bijblijven' juist relatief minder vaak. Daarbij moet echter gewezen worden op het feit dat het bij het OSA-arbeidsvraagpanel om het totale werknemersbestand gaat en bij dit pilot-onderzoek alleen om het sociaal-agogisch personeel. 


\section{CONTACTEN HSAO - WERKVELD}

\subsection{Contacten tussen HSAO en werkveld}

De werkgevers is gevraagd of zij contacten hebben met het HSAO in de regio. Dergelijke contacten zijn uiteraard zinvol bij het signaleren van kwantitatieve en kwalitatieve knelpunten in de aansluiting van HSAO'ers op de (regionale) arbeidsmarkt. In tabel 7.1. kan men aflezen dat driekwart van de onderzochte organisaties - formele dan wel informele - contacten onderhoudt met het HSAO. Van de welzijnsorganisaties heeft tweederde contact met het HSAO en van de zorginstellingen zelfs $86 \%$.

Tabel 7.1. Percentage zorg- en welzijnsinstellingen dat contacten heeft met het HSAO in de regio, percentage dat daaraan behoefte heeft en hiervan het percentage dat bepaald soort contact van belang acht voor de organisatie (meerdere antwoorden mogelijk)

\begin{tabular}{|c|c|c|c|c|}
\hline & $\begin{array}{c}\text { Zorg } \\
\%\end{array}$ & $\begin{array}{c}\text { Welzijn } \\
\%\end{array}$ & $\begin{array}{c}\text { Totaal Zor } \\
\%\end{array}$ & $\begin{array}{l}\text { Welzijn } \\
N^{30}\end{array}$ \\
\hline \multicolumn{5}{|l|}{ Momenteel contact met HSAO? } \\
\hline ja & $86 \%$ & $67 \%$ & $75 \%$ & 41 \\
\hline nee & $14 \%$ & $33 \%$ & $25 \%$ & 14 \\
\hline \multicolumn{5}{|l|}{ Behoefte aan contact? } \\
\hline ja & $90 \%$ & $81 \%$ & $85 \%$ & 44 \\
\hline nee & $10 \%$ & $19 \%$ & $15 \%$ & 8 \\
\hline \multicolumn{5}{|l|}{ Zo ja, welk contact? } \\
\hline stages studenten & $89 \%$ & $96 \%$ & $93 \%$ & 41 \\
\hline stages docenten & $28 \%$ & $31 \%$ & $30 \%$ & 13 \\
\hline werving/selectie afgestudeerden & $39 \%$ & $8 \%$ & $20 \%$ & 9 \\
\hline gastdocentschap/voorlichting & $44 \%$ & $42 \%$ & $43 \%$ & 19 \\
\hline apparatuur/ruimte aan HSAO & -- & $4 \%$ & $2 \%$ & 1 \\
\hline apparatuur/ruimte door HSAO & -- & $12 \%$ & $7 \%$ & 3 \\
\hline contractonderwijs door HSAO & $33 \%$ & $8 \%$ & $18 \%$ & 8 \\
\hline contractonderzoek door HSAO & $17 \%$ & $19 \%$ & $18 \%$ & 8 \\
\hline overleg aansluitingsproblemen & $33 \%$ & $27 \%$ & $30 \%$ & 13 \\
\hline
\end{tabular}

Hoewel de relatie tussen organisatiegrootte en het hebben van contacten met het HSAO niet eenduidig is, is het verschil tussen de zorg- en welzijnsinstellingen op dit punt voor een deel wel het gevolg van hun verschil in organisatiegrootte. Immers, slechts éénderde deel van de - zeer kleine - organisaties met minder dan 10 werknemers onderhoudt contacten met het HSAO. Kleine organisaties met tussen de 10 en 50 werknemers en zeer grote organisaties waar minimaal 200 personen werkzaam melden echter bijna allemaal contact te hebben met het HSAO (respectievelijk $94 \%$ en $100 \%$ ). Daarentegen geeft tweederde tot driekwart van de

30. In totaal hebben 52 organisaties $(=95 \%)$ de vraag naar gewenste contacten beantwoord, waarvan 44 $(=85 \%)$ positief. Doordat de werkgevers meerdere soorten gewenste contacten mochten aangeven, is de som van de aantallen bij de onderscheiden antwoordcategorieën hoger dan 44 . 
middelgrote organisaties met tussen de 50 en 200 werknemers dergelijke contacten op.

In tabel 7.1. staat eveneens vermeld of werkgevers contacten met het HSAO van belang achten voor de organisatie en zo ja, aan welke contacten zij dan behoefte hebben. In totaal stelt $85 \%$ van de onderzochte organisaties prijs op contact met het HSAO. Bij de zorginstellingen is dat $90 \%$; bij de welzijnsorganisaties $81 \%$. De organisaties die contact met het HSAO niet belangrijk vinden voor hun organisatie hebben momenteel dan ook geen contact met het HSAO. Omgekeerd zijn er wel organisaties die momenteel geen contact met het HSAO onderhouden maar die wel het belang inzien van een dergelijk contact. Dit laatste speelt vaker bij welzijnsorganisaties dan zorginstellingen.

Stages door studenten van het HSAO vinden werkgevers verreweg het belangrijkste voor hun organisatie. Daarnaast worden relatief vaak gastdocentschappen, c.q. voorlichting over werkveld aan (toekomstige) studenten HSAO en stages door docenten, evenals overleg over de aansluiting tussen het HSAO en functies in de zorg- wen welzijnssector genoemd. Bij dit laatste kan men bijvoorbeeld aan beroepenveldcommissies denken.

Daarnaast maken juist de zorginstellingen gebruik van hun contacten met het HSAO bij de werving en selectie van afgestudeerden en bij aanvullend contractonderwijs door docenten of studenten van het HSAO. Welzijnsorganisaties maken, in tegenstelling tot de verwachting, hiervan veel minder gebruik. Men zou juist verwachten dat de naar verhouding kleine welzijnsorganisaties, die immers ook vaker hun sociaal-agogisch personeel extern scholingsactiviteiten laten volgen, vaker gebruik maken van de nascholingsmogelijkheden die het HSAO biedt. Bovendien zou men juist verwachten dat de kleine welzijnsorganisaties die er meestal geen personeelsfunctionaris op na kunnen houden vaker docenten benaderen om hen te helpen bij het werven en selecteren van afgestudeerden.

\subsection{Behoefte aan regionale samenwerking}

Dit pilot-onderzoek betreft, net als de andere onderdelen van het monitoringsysteem HSAO werkveld, niet een éénmalig onderzoek, maar een instrument om knelpunten in de kwantitatieve en kwalitatieve aansluiting tussen het HSAO en de zorg- en welzijnssector periodiek op te sporen en in kaart te brengen. Het werkgeversonderzoek is er met name op gericht de kwantitatieve ontwikkelingen aan de vraagzijde van de arbeidsmarkt in de zorg- en welzijnssector op de voet te blijven volgen.

Om de resultaten van de diverse instrumenten van het monitoringsysteem optimaal te kunnen benutten bij het verbeteren van de aansluiting tussen de HSAO-opleidingen en het werkveld, zou een regionale voorziening opgezet kunnen worden die de uitvoering van de instrumenten periodiek ter hand neemt en waarbij zowel de regionale werkgevers als opleidingen zijn betrokken. Uiteraard kan een dergelijke voorziening worden toegevoegd aan een al bestaand(e) andere regionale voorziening of platform die zich met deze problematiek bezighoudt. 
In dit werkgeversonderzoek is de mening van de werkgevers over een dergelijke voorziening gepeild. Ten eerste is gevraagd of de werkgever een dergelijke regionale voorziening op prijs stelt. Indien dit het geval is hebben de werkgevers, ten tweede, kunnen aangeven of zij bij de opzet van een dergelijke regionale voorziening betrokken zouden willen worden en ten derde of zij daarin eventueel zouden willen participeren. In tabel 7.2. zijn de resultaten van deze peiling samengevat.

Tabel 7.2. Percentage zorg- en welzijnsinstellingen dat prijs stelt op regionale voorziening voor monitoringsysteem HSAO - werkveld, percentage hiervan dat bij opzet voorziening betrokken wil worden, en percentage dat wil participeren in dergelijke voorziening

\begin{tabular}{lcccc}
\hline & $\begin{array}{c}\text { Zorg } \\
\%\end{array}$ & $\begin{array}{c}\text { Welzijn } \\
\%\end{array}$ & \multicolumn{2}{c}{$\begin{array}{c}\text { Totaal Zorg- en Welzijn } \\
\%\end{array}$} \\
& & & & \\
\hline $\begin{array}{l}\text { Behoefte aan voorziening } \\
\text { ja }\end{array}$ & $68 \%$ & $54 \%$ & $60 \%$ & 28 \\
nee & $32 \%$ & $46 \%$ & $40 \%$ & 19 \\
Zo ja, betrokken bij opzet? & & & & \\
ja & $85 \%$ & $71 \%$ & $78 \%$ & 21 \\
nee & $15 \%$ & $29 \%$ & $22 \%$ & 6 \\
Zo ja, participatie? & & & & \\
ja & $92 \%$ & $71 \%$ & $81 \%$ & 21 \\
nee & $8 \%$ & $29 \%$ & $19 \%$ & 5 \\
\hline
\end{tabular}

Terwijl ruim tweederde van de zorginstellingen prijs stelt op een regionale voorziening geeft daarentegen maar de helft van de welzijnsorganisaties aan dat zij aan een dergelijke voorziening behoefte heeft. Ook dit verschil is voor een deel terug te voeren op de verschillen in organisatiegrootte. Immers de behoefte aan een regionale voorziening voor het monitoringsysteem HSAO werkveld loopt op van $46 \%$ voor de organisaties met minder dan 10 werknemers tot $100 \%$ voor de organisaties waar minimaal 200 personen werkzaam zijn. Daarnaast heeft men kunnen constateren dat de onderzochte welzijnsorganisaties ook minder vaak (behoefte aan) contact met het HSAO hebben.

Zorginstellingen stellen niet alleen vaker prijs op een regionale voorziening om het monitoringsysteem in onder te brengen, zij blijken ook relatief vaker betrokken te willen worden bij de opzet van een dergelijke voorziening en zij zouden hierin ook vaker willen participeren.

Aan de ene kant is het natuurlijk verheugend dat met name de grote (zorg)instellingen veelvuldig contact hebben of wensen met het HSAO en dat onder met name deze instellingen werkgevers in regionaal verband de knelpunten in de aansluiting tussen het HSAO en het werkveld gezamenlijk met het onderwijsveld willen oplossen. Aan de andere kant is het jammer dat de kleine (welzijns)organisaties die gezamenlijk toch een belangrijk deel van het werkveld vormen in de contacten tussen het HSAO en het werkveld ondervertegenwoordigd zijn. Het gaat hier niet alleen om kleine organisaties in het club-, buurthuis-, jeugd- en ouderenwerk, maar ook om 
$-56-$

grote organisaties waarin alleen bij specifieke diensten sociaal-agogisch personeel werkzaam is, bijvoorbeeld sociale diensten van gemeenten. Wellicht dat de komende jaren geprobeerd kan worden met name tussen dit soort instellingen en het HSAO wat meer zicht te krijgen op elkaars werk en behoeften wat betreft het sociaal-agogisch personeel. Zowel in kwantitatief als kwalitatief opzicht. 


\section{EVALUATIE EN GEBRUIKSMOGELIJKHEDEN}

\subsection{Evaluatie}

Zoals gezegd, betreft het werkgeversonderzoek een pilot-onderzoek, waarbij de werkgevers in de zorg- en welzijnssector in Noord-Nederland als 'proefpanel' hebben gefungeerd. Bij dit proefonderzoek gaat het dan ook niet alleen om de resultaten met betrekking de huidige en toekomstige vraag naar sociaal-agogisch personeel, maar eveneens om de evaluatie van het gehanteerde instrument. Het werkgeversonderzoek heeft in de eerste plaats zichtbaar gemaakt welke informatie over ontwikkelingen aan de vraagzijde van de arbeidsmarkt beschikbaar kan komen. Hierbij dient men zich te realiseren, dat dit werkgeversonderzoek één van de eerste onderzoeken in de zorg- en welzijnssector is waarbij (buiten het ministerie van WVC) inzicht ontstaat in 'harde' gegevens over werkgelegenheidsontwikkelingen en personeelsbeleid. Voor de projectadviesgroep die het monitoringsysteem heeft begeleid is dit ook éen van de belangrijkste verdiensten van dit onderzoek. De beschikbaarheid van dit type onderbouwde informatie is volgens hen een noodzakelijke voorwaarde voor gestructureerde contacten tussen het onderwijs en het werkveld. Bovendien wordt nog eens benadrukt de meerwaarde van een integrale arbeidsmarktscanner voor het HSAO en de zorg- en welzijnssector: een instrumentarium waarbij zowel de afgestudeerden van het HSAO als de werkgevers met sociaal-agogisch personeel worden benaderd.

Bij de evaluatie gaat het primair om de vraag of de geleverde informatie overeen komt met de informatiebehoefte. De evaluatie heeft op de volgende elementen betrekking:

- gebruikersgroepen;

- gebruiks- en informatiedoelen;

- instrumentarium.

\section{Gebruikersgroepen}

Het werkgeversonderzoek zou in de eerste plaats resultaten moeten opleveren voor individuele werkgevers en het georganiseerde werkveld in de zorg- en welzijnssector. Daarnaast zouden (hoge)scholen, het georganiseerde onderwijsveld evenals landelijke en regionale overheden en intermediairs op het terrein onderwijs - arbeid gebruik moeten kunnen maken van de resultaten van het werkgeversonderzoek.

\section{Gebruiks- en informatiedoelen}

Voor (individuele) werkgevers (en onderwijsinstellingen) zou het werkgeversonderzoek voornamelijk inzicht moeten bieden in het wervings-, selectie-, loopbaan-, scholings-, stage- en outplacementbeleid (in één woord: human resources management) in de zorg- en welzijnssector. Het georganiseerde werkveld (en onderwijsveld), overheden en intermediairs stellen daarnaast informatie op prijs die zij kunnen benutten bij zaken als het kwalificatiebeleid, de beroepskrachten- en onderwijsplanning, het arbeidsvoorwaardenbeleid e.d. 
Dit betekent dat het werkgeversonderzoek, in aanvulling op het afgestudeerdenonderzoek, in ieder geval (kwantitatieve) gegevens over de volgende onderwerpen dient te bevatten:

- ontwikkelingen in personeelsomvang en personeelssamenstelling (in- en uitstroom naar sexe en leeftijd);

- feitelijke werving en selectie;

- feitelijke scholingsactiviteiten, stagebeleid;

- loopbaanbeleid;

- verwachtingen werkgevers t.a.v. werkgelegenheidsontwikkeling in nabije toekomst;

- ramingen toekomstige vraag-/aanbodverhouding personeel.

De voorliggende rapportage over het werkgeversonderzoek kan inderdaad voor bovenstaande informatie(doelen) door de beoogde gebruikersgroep worden geraadpleegd. De huidige rapportage betreft echter alleen zorg- en welzijnsinstellingen in het noorden van het land. Bovendien is het werkveld van de opleiding Personeel \& Arbeid alleen in dit onderzoek betrokken voor zover het de zorg- en welzijnssector betreft. Om een goed beeld te krijgen van de huidige en toekomstige landelijke arbeidsmarktsituatie voor alle afgestudeerden van het HSAO zou het onderzoek dus in deze twee opzichten uitgebreid moeten worden. Dit heeft bovendien als voordeel dat de gegevens op een lager aggregatieniveau kunnen worden gepresenteerd. Zo kunnen dan bijvoorbeeld de gezinsvervangende tehuizen als een afzonderlijke categorie binnen de zorgsector worden onderscheiden.

Daarnaast kan men zich afvragen of de huidige rapportage - op termijn - voor alle doelgroepen voldoende gebruiksvriendelijk is. Werkgevers die gegevens hebben afgestaan ten behoeve van het onderzoek kan wellicht - als tegenprestatie - een vertrouwelijke instellingsrapportage worden geboden, waarin de resultaten over de eigen instelling worden vergeleken met de landelijke of regionale resultaten van (een groep van vergelijkbare instellingen in) de zorg-en welzijnssector. De werkgevers zouden (een deel van de) gegevens uit deze instellingsrapportages bijvoorbeeld kunnen gebruiken bij het ontwikkelen en uitvoeren van het personeelsbeleid en voor het sociaal jaarverslag.

Hoewel de huidige rapportage ook voor de andere gebruikersgroepen wel degelijk in een behoefte voorziet, zouden voor hen daarnaast ook andere produkten uitgebracht kunnen worden die nog beter op hun informatiebehoefte zijn toegesneden. Hierbij kan men denken aan een periodieke uitgave van een statistisch rapport en/of diskette met kengetallen en indicatoren omtrent de huidige en toekomstige ontwikkelingen in de aansluiting HSAO - werkveld.

\section{Instrumentarium}

Bij het pilot-onderzoek zijn de gegevens middels een schriftelijke vragenlijst verzameld. Op termijn is het wellicht mogelijk de werkgevers een (software)produkt, c.q. informatiesysteem aan te bieden, waarmee zij het eigen personeels- en scholingsbeleid goed in de gaten kunnen houden. Een soort van 'human accounting'. Eens per jaar zouden deze werkgevers dan enkele gegevens hieruit ter beschikking kunnen stellen. Een activiteit die dan tevoren is geprogram- 
meerd, zodat hiermee voor de werkgevers weinig tijd is gemoeid. Het leveren van (geaggregeerde) gegevens over het personeelsbestand met behulp van een dergelijk informatiesysteem is wellicht voor de (middel)grote instellingen aantrekkelijker dan het invullen van een vragenlijst. Voor de kleine instellingen kan dan worden volstaan met een vragenlijst die eenvoudiger kan zijn dan degene die het afgelopen jaar is gebruikt. Bovendien geldt bij een panelonderzoek dat niet ieder jaar alle gegevens opnieuw verzameld hoeven te worden. Uitgangspunt is dat het instrument voor de dataverzameling een mimimum aan inspanning van individuele werkgevers vergt, terwijl het - juist ook voor deelnemende instellingen - een maximum aan gebruikswaarde biedt.

Vanuit de projectadviesgroep is er op aangedrongen regelmatig kwalitatieve en kwantitatieve informatie te verzamelen over de arbeidsmarktontwikkelingen in de zorg- en welzijnssector aan zowel de vraag- als aanbodzijde. Een énmalig onderzoek betreft slechts een momentopname en wordt om die reden nauwelijks zinvol geacht.

Het werkgeversonderzoek is in principe opgezet als een zogenaamd 'panelonderzoek'. Hierbij wordt een representatieve groep werkgevers periodiek benaderd. Doordat steeds dezelfde groep wordt geënquêteerd ontstaat er een continue informatiestroom die een goed inzicht kan bieden in de (werkgelegenheids)ontwikkeling in instellingen. Bij cross-sectioneel onderzoek, waarbij steeds een nieuwe groep werkgevers wordt benaderd, kan men niet zien of geconstateerde veranderingen zijn toe te schrijven aan een bepaalde trendmatige ontwikkeling of een gevolg zijn van het feit dat bij herhaalde metingen de steekproef van werkgevers steeds anders is. Bij panelonderzoek kan men daarentegen voor iedere werkgever die eerder aan het onderzoek heeft deelgenomen zien welke veranderingen er hebben plaatsgevonden. Het onderzoek in de zorg- en welzijnssector is juist gericht op het in kaart brengen van dergelijke veranderingen.

Een belangrijke voorwaarde voor panelonderzoek vormt de representativiteit van de geenquêteerde werkgevers voor de zorg- en welzijnssector. Daarbij is het met name van belang dat het gekozen panel zo representatief mogelijk blijft. Zoals gezegd zou dit werkgeversonderzoek min of meer het 'spiegelbeeld' moeten vormen van het onderzoek onder de afgestudeerden van het HSAO. De representativiteit van het panel kan op twee manieren gevaar lopen. Enerzijds kan er sprake zijn van 'selectieve uitval'. Doordat bepaalde werkgevers bij volgende metingen meer responderen dan werkgevers met andere kenmerken, kan na verloop van tijd het panel niet meer representatief zijn ten opzichte van het (representatieve) panel waarmee het onderzoek is gestart. Anderzijds is het mogelijk dat door de ontwikkelingen op de arbeidsmarkt in het algemeen en de aansluiting HSAO-opleidingen en het werkveld in het bijzonder, het eerder gekozen panel niet meer een juiste afspiegeling vormt van dit werkveld. leder jaar dat het werkgeversonderzoek wordt gehouden zal dus moeten worden nagegaan of het geselecteerde panel nog wel representatief is. De vragen in de HBO-Monitor over de branches waarin de afgestudeerden van het HSAO werkzaam zijn, biedt hiertoe een goed instrument. Hierbij dient men zich wel te realiseren dat het hier gaat om de feitelijke en niet om de potentiële werkgevers van deze afgestudeerden. 
Met het oog op een standaardisering van de gegevens wordt de voorkeur gegeven aan een instrument dat op landelijk niveau wordt ontwikkeld. Uiteraard kan dit landelijke instrument, indien daar behoefte aan is, met regionale componenten worden uitgebreid. Aangezien het instrument zowel gebruikswaarde heeft voor het werkveld als het onderwijsveld zou het logisch zijn als organisaties als de VOG, het NIZW en de HBO-Raad met een aantal onderzoekers 'om de tafel gaan zitten' om gezamenlijk een 'scanner' te ontwikkelen om het personeelsbeleid en de huidige en toekomstige vraag naar sociaal-agogisch personeel jaarlijks of om het jaar in kaart te brengen.

Bij een (eventueel) verdere opzet van het werkgeversonderzoek zullen daarnaast de volgende zaken in het oog worden gehouden. Het werkgeversonderzoek is complementair aan het afgestudeerdenonderzoek. Overlap in gegevensverzameling moet dus worden vermeden. Bovendien zullen de gebruiksmogelijkheden van de arbeidsmarktscanner en de daarbij behorende doelgroepen leidraad moeten zijn bij een verdere uitwerking van het werkgeversonderzoek. Het instrument van het werkgeversonderzoek, c.q. de arbeidsmarktscanner is ten slotte niet het doel. Het instrument wordt immers opgezet om in de informatiebehoefte bij de verschillende gebruikersgroepen te voorzien.

\subsection{Gebruiksmogelijkheden arbeidsmarktscanner}

\section{Inleiding}

Aangezien het afgestudeerden- en werkgeversonderzoek complementair zijn, worden in deze paragraaf de gebruiksmogelijkheden van beide instrumenten van de arbeidsmarktscanner gezamenlijk besproken. De informatie uit beide onderzoeken vullen elkaar immers aan. Bovendien is zowel informatie over ontwikkelingen aan de vraagzijde als aan de aanbodzijde openbaar.

De resultaten van de arbeidsmarktscanner zijn voor verschillende gebruikersgroepen van belang. De belangrijkste gebruiksgroepen zijn:

- individuele onderwijsinstellingen;

- individuele werkgevers;

- georganiseerd onderwijsveld;

- georganiseerd werkveld;

- overheden;

- arbeidsbemiddelaars e.a. intermediairs op het gebied van de aansluiting onderwijs - werkveld.

Overigens is deze lijst van gebruikersgroepen niet uitputtend. Ook studenten- en beroepsverenigingen, onderzoekers, landelijke en regionale media, individuele werknemers en vakbonden kunnen voor hun activiteiten en informatiebehoefte de resultaten van de arbeidsmarktscanner gebruiken. Het zal overigens vaak voorkomen dat meerdere gebruiksgroepen bij het ontwikkelen en uitvoeren van een bepaalde activiteit zijn betrokken. 
De gebruiksmogelijkheden hebben op de volgende vier beleidsterreinen betrekking:

- voorlichting;

- kwaliteitszorg;

- scholing;

- personeelsbeleid.

Het moge duidelijk zijn dat deze vier beleidsterreinen niet los van elkaar staan. Zo kan op basis van de resultaten van de arbeidsmarktscanner worden geconcludeerd dat sommige werkaspecten tijdens de opleiding niet voldoende uit de verf komen. Bijvoorbeeld het werkaspect: 'inzicht in wettelijke regelingen'. In overleg met enkele werkgevers uit de regio kunnen hiervoor dan bijscholingscursussen worden opgezet voor oud-studenten en kunnen docenten in het werkveld stage gaan lopen om dit werkaspect later op te nemen in het curriculum. Naar aanleiding hiervan kan eventueel ook het aannamebeleid van docenten worden gewijzigd: docenten met een andere (bijvoorbeeld juridische) opleidingsachtergrond zouden dan vaker moeten worden aangetrokken om zo'n werkaspect in de opleiding te behandelen. Tenslotte kunnen (aankomende) studenten worden ingelicht over het belang van een dergelijk werkaspect.

Daarnaast kunnen de resultaten van de arbeidsmarktscanner worden gekoppeld aan het Werkveld Informatiesysteem (WIS) en de docentstages. Wanneer een hogeschool bemerkt dat de afgestudeerden van een bepaalde studierichting bijvoorbeeld vaker in een bepaalde branche gaan werken dan de hogeschool verwacht of relatief vaak aangeven dat aan een bepaald werkaspect al tijdens de opleiding meer aandacht moet worden besteed, kunnen organisaties uit de betreffende branche ook worden benaderd voor WIS en docentstages en kan in WIS en de docentstages aandacht worden besteed aan het betreffende aspect.

De arbeidsmarktscanner verschaft de gebruikersgroepen in de eerste plaats een aantal indicatoren omtrent de kwaliteit van zowel de kwantitatieve als kwalitatieve aansluiting tussen onderwijs en werkveld. Bij de kwalitatieve aansluiting gaat het dan om de afstemming binnen de werksituatie tussen de capaciteiten van een werknemer en de voor een adequate vervulling van de functie vereiste kennis en vaardigheden. Kwantitatieve aansluitingsproblemen treden op de arbeidsmarkt op wanneer er een tekort of overschot is aan arbeidskrachten voor een bepaald soort functies.

In principe hebben de uitkomsten van de HBO-Monitor, evenals de resultaten van het werkgeversonderzoek van de arbeidsmarktscanner en de andere instrumenten van het Monitoringsysteem HSAO - Werkveld tot doel het HSAO en het werkveld in onderling overleg verder te laten werken aan verbeteringen van de aansluiting tussen de opleidingen en het werkveld. De hieronder genoemde gebruiksmogelijkheden zijn slechts enige suggesties daarbij. De instrumenten van het monitoringsysteem en de resultaten die daaruit voortvloeien moeten worden opgevat als hulpmiddelen bij de verdere verbetering van deze aansluiting en niet worden beschouwd als doel op zich. 
In deze rapportage over het werkgeversonderzoek, die in eerste instantie is gericht op het werkveld in de zorg- en welzijnssector, worden hierna voor individuele werkgevers en het georganiseerde werkveld per beleidsterrein een aantal gebruiksmogelijkheden genoemd. Voor de gebruiksmogelijkheden voor andere doelgroepen wordt verwezen naar het handboek Monitoringsysteem HSAO - Werkveld, dat het NIZW medio 1993 uitbrengt.

\section{Voorlichting}

De arbeidsmarktscanner levert ondermeer over de volgende onderwerpen informatie op:

Wat betreft de afgestudeerden:

- maatschappelijke positie en arbeidsmarktloopbaan;

- beroep en branche waarin men werkzaam is;

- wijze waarop huidige baan is verworven;

- kenmerken huidige functie (dienstverband, aanstelling, wekelijkse arbeidsduur, niveau en richting functie, leidinggevend, inkomen e.d.);

- aansluiting opleiding - beroep wat betreft ruim 30 werkaspecten (belang werkaspect in functie; aandacht voor werkaspect tijdens opleiding; behoefte aan bijscholing wat betreft werkaspect);

- oordeel over stage wat betreft oriëntatie op toekomstig beroepenveld, toepassen van theorie in praktijksituatie en leren functioneren in arbeidsorganisaties;

- niveau en richting vervolgopleiding.

Verschillen tussen afgestudeerden

Het onderzoek onder de afgestudeerden geeft in de eerste plaats inzicht in de verschillen in de kwantitatieve en kwalitatieve aans/uiting tussen afgestudeerden van verschillende studierichtingen. Het is daarbij van belang om te constateren dat er niet alleen verschillen bestaan tussen studierichtingen, maar ook grote verschillen tussen afgestudeerden binnen één en dezelfde studierichting. Daarom zijn analyses verricht om na te gaan of ook andere factoren eventuele verschillen in arbeidsmarktintrede tussen de afgestudeerden nader kunnen specificeren, dan wel verklaren. Hierbij gaat het dan om verschillen in persoonskenmerken zoals leeftijd en geslacht of verschillen in kwalificaties zoals vooropleiding, studieduur, eerder genoten werk- en bestuurservaring e.d.

Wat betreft het werkveld:

- kenmerken organisatie (branche, doelgroepen, verzorgingsgebied, rechtsvorm, status vestiging en fusie, grootte organisatie);

- omvang activiteiten van organisaties uitgedrukt in totale budget, bruto totale loonsom, activiteiten (zelf gekozen meeteenheid) en percentage van budget dat gesubsidieerd is;

- samenstelling en ontwikkeling sociaal-agogisch personeel (formatieplaatsen, instroom en uitstroom en stand einde jaar van werknemers onderverdeeld naar leeftijdsklasse en geslacht);

- werving en selectie van sociaal-agogisch personeel (onderverdeeld naar opleiding, werkervaring en wervingskanaal); inzicht in verdringing tussen bepaalde groepen afgestudeerden;

- verwachtingen voor werkgelegenheids- en vacatureontwikkeling voor (sociaal-agogisch) personeel in nabije toekomst; 
- indicatieve ramingen voor verwachte uitbreidings- en vervangingsvraag voor sociaal-agogisch personeel in nabije toekomst;

- scholingsbeleid voor sociaal-agogisch personeel;

- (gewenste) contacten tussen onderwijs en werkveld.

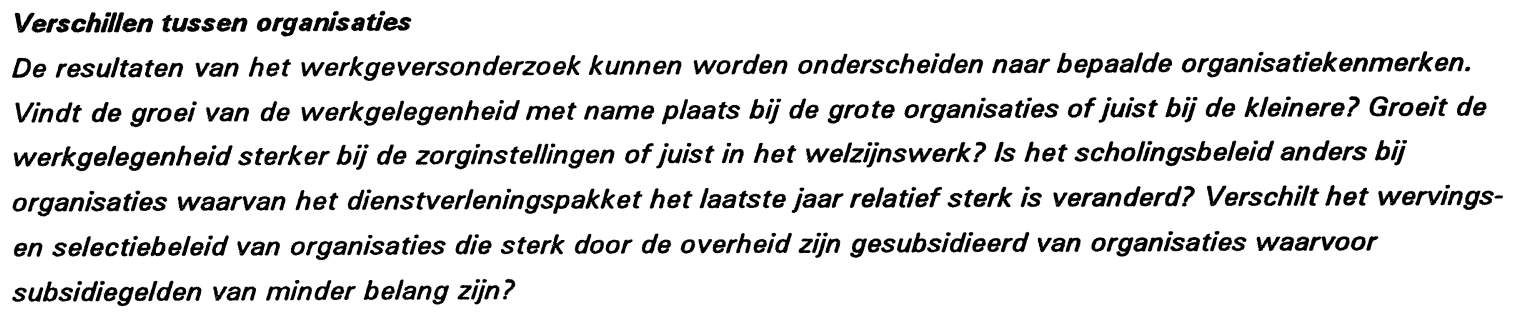

(Individuele) werkgevers kunnen de uitkomsten van de arbeidsmarktscanner bij de volgende voorlichtingsactiviteiten gebruiken:

- deelname aan of organisatie van bedrijveninformatiedagen;

- organiseren van bedrijfsexcursies voor afgestudeerden, (aankomende) studenten en hun ouders, decanen en docenten voor realistische beeldvorming van feitelijke werkzaamheden en arbeidsomstandigheden in een bepaald beroep of in een bepaalde branche;

- deelname aan of organisatie van discussiemiddagen over aansluiting onderwijs - werkveld.

Het georganiseerde werkveld kan informatie verschaffen over de arbeidsmarktscanner aan:

- individuele onderwijsinstellingen en werkgevers;

- andere branche-organisaties;

- vakbonden;

- (landelijke) overheden, intermediairs.

\section{Kwaliteitszorg}

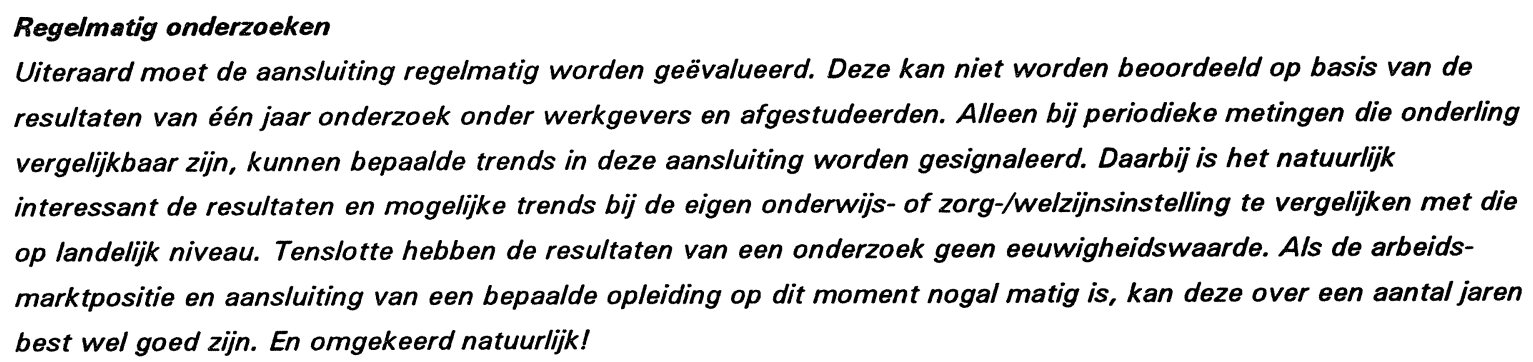

Individuele werkgevers kunnen de resultaten uit de arbeidsmarktscanner als volgt gebruiken:

- evaluatie en eventueel aanpassen van beleid t.a.v. werving en selectie;

- evaluatie en eventueel aanpassen van scholingsbeleid;

- evaluatie en eventueel aanpassen functie(profielen);

- aanbod (van eventueel ander soort) stageplaatsen voor studenten en docenten. 
In het georganiseerde werkveld kunnen de resultaten van de arbeidsmarktscanner voor de volgende activiteiten worden benut:

- opstellen van beroepsprofielen in overleg met beroepenveldcommissies (waarin ook georganiseerde onderwijsveld is vertegenwoordigd);

- formuleren van (landelijke) criteria voor kwaliteitsbewaking;

- overleg met bijvoorbeeld ministerie van WVC, HBO-Raad, andere branche-organisaties e.d.

\section{Scholing}

Uit de resultaten van de arbeidsmarktscanner (en het WIS) kunnen (individuele) werkgevers afleiden op welke terreinen behoefte bestaat aan bijscholing. De bijscholingsbehoefte kan zowel op kennis, vaardigheden als houdingsaspecten betrekking hebben.

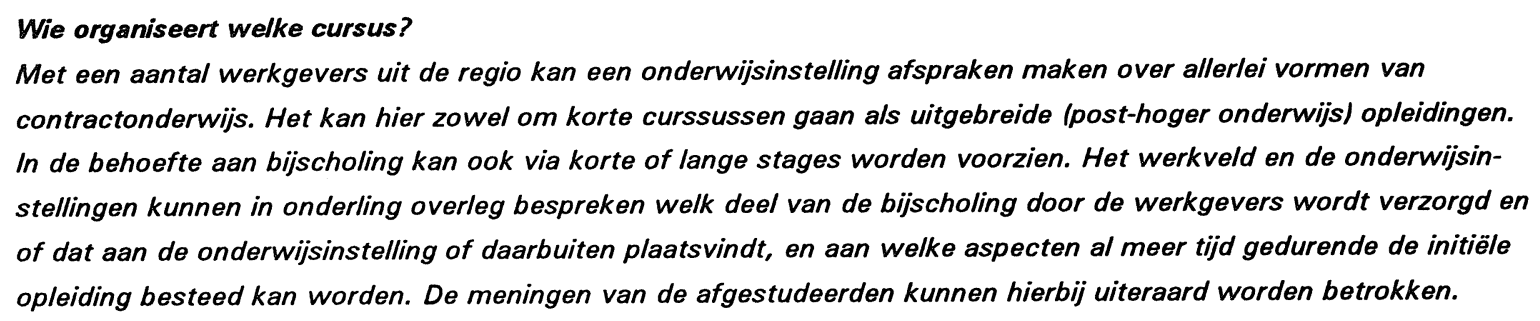

(Individuele) werkgevers kunnen, in overleg met regionaal onderwijsveld, bijscholingsactiviteiten (inclusief korte en lange stages) opzetten voor:

- hun eigen of andere werknemers;

- studenten;

- werkzoekenden (inclusief potentiële herintreders);

- docenten.

Individuele werkgevers en onderwijsinstellingen zullen zich bij het aanbod van bijscholingscursussen e.d. met name richten op de regionale markt. Het georganiseerde werkveld kan al dan niet gezamenlijk met het onderwijsveld op regionaal of landelijk niveau, de (gewenste) scholingsactiviteiten van individuele onderwijsinstellingen en werkgevers gaan coördineren.

\section{Personee/sbeleid}

De gegevens uit de arbeidsmarktscanner spelen voor individuele werkgevers een directe rol bij het personeelsbeleid. De arbeidsmarktscanner biedt indicatoren die voor de volgende elementen van het personeelsbeleid van belang kunnen zijn:

- wervings- en selectiebeleid; marktpositie organisatie bij aantrekken personeel;

- loopbaanbegeleiding;

- functie-analyse en functiewaardering. 


\section{Wervingsstrategie}

Uit de sectorrapportages kan bijvoorbeeld worden afgeleid op welke wijze afgestudeerden van een bepaalde studierichting hun baan hebben gevonden. Het kan zijn dat een werkgever merkt dat hij of zij deze afgestudeerden moeilijk kan bereiken. Deze resultaten geven wellicht aanleiding een andere wervingsstrategie te kiezen. Bovendien kan een werkgever op basis van het verslag van het werkgeversonderzoek zijn eigen wervingsbeleid vergelijken met die van andere werkgevers in de sector. Het kan zijn dat een werkgever in vergelijking met andere werkgevers naar verhouding veel MBO-ers selecteert of vaak mensen met een aantal jaren werkervaring, terwijl andere werkgevers in de sector vaker hun voorkeur geven aan HBO-ers of mensen zonder veel werkervaring.

Voor het georganiseerde werkveld liggen de gebruiksmogelijkheden van de arbeidsmarktscanner wat betreft personeelsbeleid op een wat hoger aggregatieniveau. In principe gaat het om dezelfde onderwerpen als bij de individuele werkgevers zijn genoemd. Alleen betreft het nu niet een individuele werkgever, maar een (deel van een) bepaalde branche in de zorg- en welzijnssector. Bovendien kunnen de resultaten van de arbeidsmarktscanner worden benut bij het overleg met de werknemersorganisaties.

\section{Opbrengst panelonderzoek}

De resultaten van het werkgeversonderzoek geven nu al veel inzicht in de ontwikkelingen aan de vraagzijde van de zorg- en welzijnssector. Doordat het hier gaat om een panelonderzoek waarbij in principe steeds dezelfde organisaties worden betrokken, kunnen echter ook heel specifieke vragen worden beantwoord. Daarbij gaat het om vragen als: Welke factoren bepalen de werkgelegenheidsontwikkeling bij een organisatie? Wat zijn de effecten van bijvoorbeeld vergrijzing van het personeelsbestand voor de scholingsbehoeften van een organisatie? 


\section{LITERATUUR}

Allaart, P.C., W.C.M. Praat, J.P.M. Vosse (1992), Trendrapport Vraag naar arbeid 1992, OSArapport nr. 16, Stichting Organisatie voor Strategisch Arbeidsmarktonderzoek (OSA), Den Haag.

Centraal Bureau voor de Statistiek (1991), Statistiek van het hoger beroepsonderwijs 1989/'90, instellingen en studenten, CBS-publikaties, SDU-uitgeverij, Den Haag.

Centraal Bureau voor de Statistiek (1989, 1990, 1991), Enquête Beroepsbevolking 1988, 1989, 1990, Centraal Bureau voor de Statistiek, Voorburg/Heerlen.

Commissie Ontwikkeling Kwalificatiestelsel Zorg \& Welzijn (1991), Het kwalificatievraagstuk in de sector zorg \& welzijn, Stand van zaken en perspectief, interim-rapport, Nederlands Instituut voor Zorg en Welzijn (NIZW), Utrecht.

Dam, J.W. van, M. Mortier (1990), Inventarisatie van arbeidsmarktonderzoek onder afgestudeerden van het $H B O, R O A-W-1990 / 1$, Maastricht.

Dam, J.W. van, A. de Grip, J.A.M. Heijke (1988), Op zoek naar informatiebronnen over de arbeidsmarktpositie van academici, ROA-W-1988/3, Maastricht.

Dam, J.W. van, J.A.M. Heijke, G. Ramaekers (1989), Ontwerp van een arbeidsmartkscanner voor academici, ROA-R-1989/3, Maastricht.

Dekker, R.J.P., A. de Grip, P.J.E. van de Loo (1990), ROA-beroepenclassificatie 1990, ROA-W$1990 / 9$.

Dekker, R.J.P., A. de Grip, H. Berendsen, M.H. Wieling, E.J.T.A. Willems (1992), Methodiek en structuur arbeidsmarktmodule I-See! 1991, ROA-W-1992/1, Maastricht.

Grip, A. de, J.W. van Dam (1989), Evaluatie van de RUBS-schoolverlatersenquête 1989, ROAR-1990/2, Maastricht.

Grip, A. de, E.J.T.A. Willems (1992), De vervangingsvraag naar beroepsklasse tot 2000, OSAwerkdocument W96, Organisatie voor Strategisch Arbeidsmarktonderzoek (OSA), Den Haag.

Loo, P.J.E. van de, G.W.M. Ramaekers, R.K.W. van der Velden (1992), De arbeidsmarktpositie van afgestudeerden van het hoger sociaal-agogisch onderwijs 1991, landelijke sectorrapportage HSAO, HBO-Monitor, Voorlichtingsdienst HBO-Raad, Den Haag.

Ministerie van Onderwijs en Wetenschappen (1991), HBO verdeelraming 1991, een raming van studentenaantallen binnen het kader van de Referentieraming 1991, Ministerie van Onderwijs en Wetenschappen, Zoetermeer. 
Ramaekers, G.W.M., J.A.M. Heijke (1991), Arbeidsmarktscanner Rijksuniversiteit Limburg, Afgestudeerden 1986-1989, ROA-R-1991/6, Maastricht.

Researchcentrum voor Onderwijs en Arbeidsmarkt (1992), De arbeidsmarkt naar opleiding en beroep tot 1994, ROA-R-1992/1, Maastricht.

Researchcentrum voor Onderwijs en Arbeidsmarkt (1992), De arbeidsmarkt naar opleiding en beroep tot 1994, statistische bijlage, ROA-R-1992/1B, Maastricht.

Researchcentrum voor Onderwijs en Arbeidsmarkt (1992), De arbeidsmarkt naar opleiding en beroep tot 1994, statistische bijlage, Actualisering 1992, ROA-R-1992/1B, Maastricht.

Tijdelijke Adviescommissie Onderwijs-Arbeidsmarkt (1990), Onderwijs-arbeidsmarkt: naar een werkzaam traject, eindrapport van de commissie Rauwenhoff, Samson, H.D. Tjeenk Willink, Alphen aan den Rijn.

Top, G.J., van der (1989), Herkenbare kwaliteit, Eindrapport van de adviescommissie hoger sociaal-agogisch onderwijs, HBO-Raad, Den Haag.

Willems, E.J.T.A., A. de Grip (1990), Vervangingsvraagprognoses naar beroep en opleiding, ROA-W-1990/7, Maastricht. 


\section{BIJLAGE 1. INDELING VAN ORGANISATIES IN ZORG- EN WELZIJNSINSTEL- LINGEN}

Indeling van organisaties in zorg- en welzijnsinstellingen

\section{ZORGINSTELLINGEN}

Algemene ziekenhuizen (incl. academische)

$\begin{array}{ll}\text { Gespecialiseerde ziekenhuizen (excl. psychiatrische) } & 1\end{array}$

Psychiatrische inrichtingen en verslavingsklinieken

(incl. rijksinrichtingen voor ter beschikking gestelden) 4

Zwakzinnigeninrichtingen (excl. gezinsvervangende tehuizen) 2

Verpleeghuizen voor enkelvoudig- en meervoudig zieken/gehandicapten 3

Medische dagverblijven voor geestelijk of meervoudig gehandicapten $\quad 1$

Murale maatschappelijke dienstverlening:

Bejaardentehuizen 2

Gezinsvervangende tehuizen voor normaalbegaafde kinderen $\quad 7$

Gezinsvervangende tehuizen voor geestelijk of meervoudig gehandicapten 1

$\begin{array}{ll}\text { Totaal zorginstellingen } & 22\end{array}$

WELZIJNSINSTELLINGEN

Ambulante geestelijke gezondheidszorg $\quad 1$

Semi-murale sociale kinderopvang $\quad 1$

Algemeen maatschappelijk werk 3

Eerstelijns maatschappelijke en rechtskundige hulp- en adviesorganisaties 3

Advies- en opvangcentra voor jongeren 1

Crisisinterventiecentra 1

Centrale voor pleeggezinnen, kinderbeschermingsverenigingen $\quad 1$

Speelzalen e.a. kinderdagverblijven voor normaalbegaafde kinderen 3

Dienstverlening t.b.v. het onderwijs 1

Algemeen buurt- en clubhuiswerk 1

Categoraal buurt- en clubhuiswerk $\quad 4$

Categoraal opbouwwerk $\quad 1$

Vormingswerk 2

Arbeidsbemiddelingsbureau's (non-profit) 1

Gemeenten (Diensten Sociale Zaken) 3

Gemeentelijke kredietbanken $\quad 1$

Provinciale raden voor de kinderbescherming $\quad 3$

Provinciale Reclasseringsinstellingen $\quad 2$

Totaal welzijnsinstellingen $\quad 33$

$\begin{array}{ll}\text { Totaal zorg- en welzijnsinstellingen } & 55\end{array}$ 


\section{BIJLAGE 2. SAMENSTELLING SOCIAAL-AGOGISCHE BEROEPENCLUSTERS}

Samenstelling sociaal-agogische beroepenclusters

Beroepenclusters:

Maatschappelijk werkers (MW)

- algemeen maatschappelijk werker

- maatschappelijk werker kinderbescherming

- bedrijfsmaatschappelijk werker

- contactambtenaar, maatschappelijk werker sociale of geneeskundige dienst (gemeente, provincie, rijksoverheid)

- medisch/psychiatrisch maatschappelijk werker

- sociotherapeutisch medewerker, reclasseringsambtenaar

- categoraal maatschappelijk werker (woonwagenwerk, minderheden)

Sociaal-pedagogische hulpverleners (SPH)

- inrichtingswerker

- aktiviteitenbegeleider, spelleider

- creatief therapeut

- groepsleider dagvoorziening

Cultureel werkers (CW)

- (sociaal-)cultureel werker

- opbouwwerker

Personeelswerkers (PW)

- personeelsfunctionaris

- beroepskeuze-adviseur, arbeidsbemiddelaar

- functie-analist, personeelsorganisatie-adviseur

Beleidsmedewerkers (BMW)

- welzijnsambtenaar

- overige beleidsmedewerkers op sociaal-agogisch vakgebied

Leidinggevenden zorg en welzijn (LGZW)

- afdelingshoofd/coördinator in maatschappelijk/cultureel werk

- coördinator/leidinggevende dagvoorziening

- hoofd bejaarden-/gezinshulpdienst

- hoofd verpleegkundige/verzorgende dienst of tehuis

- hoofd afdeling personeelszaken, sociale en/of juridische zaken e.d.

- directeur stichting, vereniging NV, coöperatie, overheidsbedrijf in zorg- of welzijnssector 


\section{BIJLAGE 3. RESULTATEN PANELONDERZOEK PERSONEEL \& ARBEID}

Tabel B.3.1. Aantal formatieplaatsen (f.t.e.'s) voor P\&O-functies in profit- en non-profitorganisaties die geen andere sociaal-agogische formatieplaatsen hebben, eind 1991

\begin{tabular}{lccc} 
Aantal formatieplaatsen & profit & non-profit & totaal \\
\hline $\begin{array}{l}\text { Beroepenclusters P\&O } \\
\text { personeelswerkers' } \\
\text { beleidsmedewerkers P\&O }\end{array}$ & 7 & 43,5 & 50,5 \\
leidinggevenden P\&O & 2 & 2 & 4 \\
totaal f.t.e. P\&O & 9 & 2,3 & 11,3 \\
aantal organisaties (N) & 18 & 47,8 & 65,8 \\
& 6 & 4 & 10
\end{tabular}

Indeling beroepenclusters P\&O

1: personeelswerkers:

- personeelsfunctionaris

- beroepskeuze-adviseur, arbeidsbemiddelaar

- functie-analist, personeelsorganisatie-adviseur

2: beleidsmedewerkers $\mathrm{P} \& \mathrm{O}$ :

- welzijnsambtenaar t.b.v. personeels-/organisatiebeleid

- overige beleidsmedewerkers op personeels-/organisatiegebied

3: leidinggevenden $\mathrm{P \& O}$ :

- hoofd afdeling personeelszaken (P\&O), sociale en/of juridische zaken e.d.

- directeur stichting, vereniging, NV, coöperatie, overheidsbedrijf e.d. 